NAA-SR-3829

REACTORS POWER

162 PAGES

\title{
AN ADVANCED SODIUM-GRAPHITE REACTOR NUCLEAR POWER PLANT
}

\author{
by \\ J. R. Churchill \\ J. Renard
}

ATOMICS INTERNATIONAL

A Division of North American Aviation, Inc.

P. O. Box $309 \quad$ Canoga Park, California 


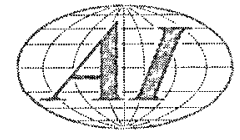

\section{DISTRIBUTION}

This report has been distributed according to the category "Reactors-Power" as given in "Standard Distribution Lists for Unclassified Scientific and Technical Reports" TID-4500 (15th Ed.), August 1, 1959. A total of 620 copies was printed. 


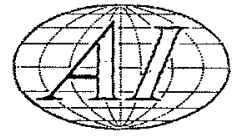

CONTENTS

Abstract . . . . . . . . . . . . . . . . . . . . iv

I. Introduction . . . . . . . . . . . . . . . . . . . 1

II. Reactor . . . . . . . . . . . . . . . . . . . . 3

A. Reactor Core .. . . . . . . . . . . . . . . . . . . . . . 3

1. Calandria Vessel . . . . . . . . . . . . . . . 3

2. Fuel Element and Orifice Tube . . . . . . . . . . . 3

3. Control Rod and Drive Mechanism . . . . . . . . . 4

4. Neutron Source . . . . . . . . . . . . . . . 5

5. Reactor Heat Transfer . . . . . . . . . . . . . 5

6. Reactor Physics . . . . . . . . . . . . . . . 5

B. Reactor Structure . . . . . . . . . . . . . . . . 7

1. Neutron Șhield . . . . . . . . . . . . . . . . . . 7

2. Reactor Vessel Assembly. . . . . . . . . . . . . . . 8

3. Heat Exchanger and Pump Removal Plugs . . . . . . . 8

4. Containment Vessel . . . . . . . . . . . . . . 9

5. Support Structure . . . . . . . . . . . . . . 9

6. Loading Face Shield . . . . . . . . . . . . . . . . . . . $\quad$. 9

III. Secondary Sodium Heat Transfer System . . . . . . . . . . . . 9

A. General . . . . . . . . . . . . . . . . . . . 3

B. Steam Generator . . . . . . . . . . . . . . . . 9

C. Secondary Sodium Pumps . . . . . . . . . . . . . . . 10

D. Valves . . . . . . . . . . . . . . . . . . . 10

E. Expansion Tanks . . . . . . . . . . . . . . . . 10

F. Secondary Sodium Piping . . . . . . . . . . . . . . . . . 10

G. Sodium Service System . . . . . . . . . . . . . . . 10

H. Filling . . . . . . . . . . . . . . . . . . . . 10

I. Draining . . . . . . . . . . . . . . . . . . . 11

J. Sodium Purification . . . . . . . . . . . . . . . 11

K. Calandria Sodium Pump-Out System . . . . . . . . . . 11

L. Sodium Preheating System . . . . . . . . . . . . . 12

IV. Reactor Auxiliary Systems . . . . . . . . . . . . . . 12

A. Water Cooling System . . . . . . . . . . . . . . . . 12

B. Inert Gas System . . . . . . . . . . . . . . . . 14

1. Nitrogen System . . . . . . . . . . . . . . . 14

2. Helium System . . . . . . . . . . . . . . . 15

C. Radioactive Vent System . . . . . . . . . . . . . . . . . 15

D. Radioactive Liquid Waste System . . . . . . . . . . . 16

V. Fuel Handling System . . . . . . . . . . . . . . . . . 16

A. General . . . . . . . . . . . . . . . . . . . 16

B. System and Component Description . . . . . . . . . . 17

1. New Fuel Shipping Containers . . . . . . . . . . . . 17

2. New Fuel Storage Racks . . . . . . . . . . . . 17

3. Preheat Cells . . . . . . . . . . . . . . . . 17

4. Fuel Storage Thimbles . . . . . . . . . . . . . 17

5. Fuel Transfer Cask . . . . . . . . . . . . . . 17

6. Fuel Shipping Cask . . . . . . . . . . . . . . . 17

C. Fuel Handling Procedure . . . . . . . . . . . . . . . 17 


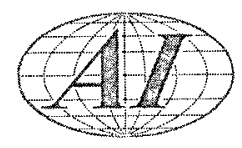

CONTENTS

VI. Instrumentation and Control . . . . . . . . . . . . . . . . . . 18

A. Reactor Instrumentation . . . . . . . . . . . . . . 18

1. Flux Instrumentation . . . . . . . . . . . . . . . . . . 18

2. Temperature Instrumentation . . . . . . . . . . . 18

3. Sodium and Reactor Auxiliary Systems . . . . . . . . 18

B. Plant Control System . . . . . . . . . . . . . . . . . 18

VII. Turbine-Generator Plant . . . . . . . . . . . . . . . 19

A. Steam System . . . . . . . . . . . . . . . . . 19

1. General . . . . . . . . . . . . . . . . . . 19

2. Steam Generating Equipment . . . . . . . . . . . 19

3. Turbine-Generator and Auxiliaries . . . . . . . . . . . 19

4. Condenser and Auxiliaries . . . . . . . . . . . . . 20

5. Feedwater System . . . . . . . . . . . . . . . 20

6. Water Supply System . . . . . . . . . . . . . . 21

7. Piping . . . . . . . . . . . . . . . . . . 21

8. Steam Generator Warmup System . . . . . . . . . 21

9. Emergency Cooling . . . . . . . . . . . . . . 21

B. Electrical . . . . . . . . . . . . . . . . . . . 21

1. Generator and Connections . . . . . . . . . . . . 21

2. Main Power Transformer . . . . . . . . . . . . 21

3. High Voltage Switchyard . . . . . . . . . . . . 22

4. Protective Relaying . . . . . . . . . . . . . . 22

5. Station Auxiliary Power System . . . . . . . . . . 22

6. Auxiliary Power Transformers . . . . . . . . . . . . . 22

7. 4160-Volt Switchgear . . . . . . . . . . . . . . 22

8. 480-Volt Load Centers . . . . . . . . . . . . . . . . 22

9. 480-Volt Motor Control Centers . . . . . . . . . . 23

10. Emergency Power System . . . . . . . . . . . . 23

11. Motors . . . . . . . . . . . . . . . . . . 23

12. Communications . . . . . . . . . . . . . . . 23

VIII. Site and Building . . . . . . . . . . . . . . . . . . . . . . 24

A. Plant Site . . . . . . . . . . . . . . . . . . . 24

1. Plant Outline Specifications . . . . . . . . . . . . . . 24

2. Site and Site Services . . . . . . . . . . . . . . 24

3. Grading and Drainage . . . . . . . . . . . . . . . 24

4. Utilities . . . . . . . . . . . . . . . . . . 24

B. Building and Building Services . . . . . . . . . . . . 24

1. Reactor Area . . . . . . . . . . . . . . . . . 24

2. Reactor Auxiliary Bay Area . . . . . . . . . . . 25

3. Administration and Service Area . . . . . . . . . . 25

4. Decontamination Area . . . . . . . . . . . . . 25

C. Fire Protection System . . . . . . . . . . . . . . . . 25

D. Heating, Ventilating, and Air Conditioning . . . . . . . . 25

IX. Safety Characteristics . . . . . . . . . . . . . . . . 26

A. Introduction . . . . . . . . . . . . . . . . . . . 26

1. Reactor Thermal Safety . . . . . . . . . . . . . 27

2. Reactor Nuclear Safety . . . . . . . . . . . . . 27

B. Structural Safety of Reactor Area . . . . . . . . . . . . . 27

1. Reactor Structure and Containment Features . . . . . . 27

2. Substructure . . . . . . . . . . . . . . . . 28 


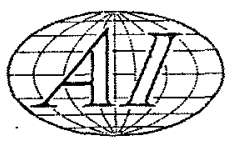

\section{CONTENTS}

C. Reactor Plant Protective System . . . . . . . . . . . . . . . 28

1. Design Emphasis . . . . . . . . . . . . . . . . . . 28

D. Safety Features . . . . . . . . . . . . . . . . . 30

1. Control-Safety Rods . . . . . . . . . . . . . . 30

2. Plant Control System . . . . . . . . . . . . . 30

3. Alternate Electric Power Sources . . . . . . . . . . 31

4. Heat Removal Characteristics . . . . . . . . . . . 31

5. Reactivity Coefficients . . . . . . . . . . . . . 31

6. Ultimate Shutdown Mechanism . . . . . . . . . . 32

E. Transients . . . . . . . . . . . . . . . . . . 32

1. Cause and Prevention . . . . . . . . . . . . . . . . 32

2. Transients . . . . . . . . . . . . . . . . . 32

3. Coolant Flow Accident . . . . . . . . . . . . . 32

4. Sodium Inlet Temperature Transients . . . . . . . . . 32

F. Radiation Hazard Control . . . . . . . . . . . . . . 32

1. Operation Exposure to Ionizing Radiation . . . . . . . 32

2. Control of Gaseous and Particulate Radioactive Material . . 33

3. Radioactive Liquid Waste . . . . . . . . . . . . . 33

4. Emergency Procedures and Recommendations . . . . . . 33

X. Economics . . . . . . . . . . . . . . . . . . . 33

A. Power Generating Costs . . . . . . . . . . . . . . 33

B. Capital Investment . . . . . . . . . . . . . . . . . 34

C. Fuel Cycle Costs . . . . . . . . . . . . . . . . . . . . 36

References . . . . . . . . . . . . . . . . . . . 42

Appendix . . . . . . . . . . . . . . . . . . . 43

\section{TABLES}

I. Plant Data . . . . . . . . . . . . . . . . . . . . . 2

II. Neutron Balance for 255-Mwe Advanced Sodium Graphie Reactor . . 6

III. Water-System Cooling Loads for Reactor Components . . . . . . 13

IV. Setback. . . . . . . . . . . . . . . . . . . . . 30

V. Reactor Scram . . . . . . . . . . . . . . . . . . . . . . 30

VI. 256-Mwe Advanced Sodium Graphite Reactor Capital-Cost Estimate . 34

VIII. 256-Mwe Advanced Sodium Graphite Reactor Fuel-Cycle Costs . . . 36

IX. Equipment List . . . . . . . . . . . . . . . . . . 37 



\section{INTRODUCTION}

The nuclear power plant described in this study has a net electrical generating capacity of $256 \mathrm{Mw}$, based on a turbine-generator operating at 1.5 in. of $\mathrm{Hg}$ absolute back pressure, 2400 psig steam at $1050^{\circ} \mathrm{F}$ at the turbine throttle, with resuperheating to $1000^{\circ} \mathrm{F}$, and seven regenerative feedwater heating stages. The reactor is thermal in neutron spectrum, fueled with UC, cooled by sodium, and moderated with graphite. A calandria vessel contains the graphite moderator and reflector, and is pierced by through-tubes (process tubes) which contain the fuel elements. The calandria itself is located in a tank of sodium. A neutron shield of iron and titanium hydride surrounds the calandria vessel. Three sodium-tosodium heat exchangers are located in the annulus between the neutron shield and the outer sodium container.

Linear induction pumps, located outside the primary sodium container and below the intermediate heat exchangers, are used to pump primary sodium to a plenum chamber below the calandria, thence upward through the calandria-core process tubes, into a top pool, over the neutron-shield wall, and downward through the intermediate heat exchangers. Nonradioactive sodium, heated by primary sodium, is pumped from the tube side of each intermediate heat exchanger to a steam generator.

Superheated steam produced in the steam generators $\left(2400 \mathrm{psig} / 1050^{\circ} \mathrm{F}\right)$ flows to a common header which serves a single three-cylinder turbine. A reheatregenerative cycle is utilized; the steam is partially expanded through the high-pressure turbine cylinder and returned to a sodium reheater. Steam is resuperheated to $1000^{\circ} \mathrm{F}$ in this reheater and expanded again through the lower pressure turbine stages. Steam is extracted at seven stages in the turbine for regenerative feedwater heating.

A sodium service system is used to fill, drain, and flush the sodium heat transfer system. The sodium service system contains a purification system which removes sodium oxide to a point $(<10 \mathrm{ppm})$ at which corrosion is negligible. A nitrogen system provides an inert atmosphere within the reactor container, and at all points where a free surface of sodium exists. Nitrogen also blankets the shielded cells which contain the primary sodium service system. Radioactive liquid- and gaseous-waste systems are provided to remove, store, and dispose of radioactive wastes accumulated in the equipment cleaning facilities and personnel decontamination room. A water cooling system provides auxiliary cooling to concrete biological shielding installed around the reactor, certain sodium handling components, and the shielded radioactive cells which contain a nitrogen atmosphere.

The fuel handling system consists of a fuel handling cask, fuel storage cells, and the necessary equipment for receiving new fuel, refueling the reactor, and shipping spent fuel. The fuel handling cask, which must have access to a major portion of the reactor floor, is supported on a gantry crane.

A plant control system allows automatic operation over the range of 20 to $100 \%$ load or manual operation at any load. The plant is designed to operate on a load-following basis. System frequency regulates the throttle valves, and voltage controls generator excitation. Feedwater flow is controlled by a threefunction controller with feedwater flow, steam flow, and the sodium outlet temperature from the steam generator as controller variables. Steam pressure ahead of the turbine throttle is used to control the primary sodium flow through the steam generators, thereby controlling the rate of steam generation. The bulk temperature of the coolant out of the reactor is used to control reactor power by positioning control rods. A plant protective system provides rapid detection of any off-normal condition in the reactor plant and automatically takes corrective action. This action may involve an alarm, setback, or scram. All power plant control is from a central area which integrates both reactor and turbine-generator instrumentation. Monitoring systems, with alarms to indicate radiation levels in excess of predetermined values, are provided.

The hypothetical site is a level area adjacent to a river, in a temperate zone, with highway, railroad, and river-barge services available. The reactor, reactor service systems, fuel handling system, and control and office areas are enclosed by a single structure, and the turbine-generator is located outdoors. The reactor and radioactive portions of the systems are contained in shielded cells. The reactor bay of the building is serviced by a 30-ton bridge crane in addition to the gantry crane used for fuel handling and reactor equipment installation and maintenance. A 75-ton bridge crane services the reactor auxiliary bay and steam plant. The high-voltage switchyard, cooling-water intake and discharge structures, and liquid-waste treatment system are remote from the building. 
TABLE I

PLANT DATA

\begin{tabular}{|c|c|}
\hline Main Steam Pressure & 2400 psig \\
\hline Main Steam Temperature & $1050^{\circ} \mathrm{F}$ \\
\hline Reheat Steam Pressure & 504 psig \\
\hline Reheat Steam Temperature & $1000^{\circ} \mathrm{F}$ \\
\hline Throttle Steam Flow & $1.835 \times 10^{6} \mathrm{lb} / \mathrm{hr}$ \\
\hline Number of Feedwater Heaters & 7 plus evaporator \\
\hline Feedwater Temperature & $540^{\circ} \mathrm{F}$ \\
\hline Condenser Back Pressure & $11 / 2$ in. $\mathrm{Hg}$ absolute \\
\hline Gross Electrical Power & $270 \mathrm{Mw}$ \\
\hline Net Electrical Power & $255.9 \mathrm{Mw}$ \\
\hline Gross Turbine-Cycle Heat Rate & $7550 \mathrm{Btu} / \mathrm{kwh}$ \\
\hline Net Turbine-Cycle Heat Rate & $7750 \mathrm{Btu} / \mathrm{kwh}$ \\
\hline Steam-Raising Plant Efficiency & $98.5 \%$ \\
\hline Net Plant Heat Rate & $8090 \mathrm{Btu} / \mathrm{kwh}$ \\
\hline \multicolumn{2}{|l|}{ Reactor } \\
\hline Reactor thermal power & $606 \mathrm{Mw}$ \\
\hline Reactor coolant & sodium \\
\hline Coolant temperatures & $650^{\circ} \mathrm{F}$ inlet, $1200^{\circ} \mathrm{F}$ outlet \\
\hline Coolant flow & $12.6 \times 10^{6} \mathrm{lb} / \mathrm{hr}$ \\
\hline Number of primary loops & 3 \\
\hline Secondary coolant & sodium \\
\hline Coolant temperature & $600^{\circ} \mathrm{F}$ inlet, $1150^{\circ}$ outlet \\
\hline Coolant flow & $12.6 \times 10^{6} \mathrm{lb} / \mathrm{hr}$ \\
\hline Fuel & $\begin{array}{l}\text { 19-rod cluster of } 1 / 2 \text {-in.-diam by } 1 \text {-in. UC pellets in } \\
\text { SS tubes with } \mathrm{Na} \text { bond }\end{array}$ \\
\hline Number of fuel elements & 151 \\
\hline Number of control-safety rods & 18 \\
\hline Initial enrichment & 2.7 at. $\% U^{235}$ \\
\hline $\begin{array}{l}\text { Initial excess reactivity with equilibrium } X e \text { and } \\
S m \text { poison }\end{array}$ & 0.127 \\
\hline Initial conversion ratio & 0.505 \\
\hline Average fuel burnup & $17,100 \mathrm{Mwd} / \mathrm{MTU}^{*}$ \\
\hline Uranium in core & $16,200 \mathrm{~kg}$ \\
\hline Active core size & $12-\mathrm{ft}$ diam by $12 \mathrm{ft} \mathrm{high}$ \\
\hline Peak-to-average power ratio & 2.87 \\
\hline Specific power (average for new core) & $1400 \mathrm{kw} / \mathrm{kg} \mathrm{U} \mathrm{U}^{235}$ \\
\hline Maximum fuel temperature & $2250^{\circ} \mathrm{F}$ \\
\hline Average heat flux & $425,000 \mathrm{Btu} / \mathrm{hr}-\mathrm{ft}^{2}$ \\
\hline Average thermal neutron flux in fuel & $8 \times 10^{13} \mathrm{n} / \mathrm{cm}^{2}-\mathrm{sec}$ \\
\hline
\end{tabular}

* Mwd $/ M T U=$ megawatt days per metric ton of uranium. 

No full-scale fuel elements of UC have yet been tested, but a number of capsule irradiations have been conducted and the results analyzed. Most tests have been conducted with temperatures near $1600^{\circ} \mathrm{F}$, although a peak têmperature of about $1900^{\circ} \mathrm{F}$ was reached in one capsule. Maximum exposure to date is about 14,000 Mwd/MTU. All tests have shown excellent radiation stability and fission gas retention, and more capsule tests at higher temperatures (to 2500 or $3000^{\circ} \mathrm{F}$ ); higher exposures are underway or in preparation. Uranium carbide elements will be inserted into the Sodium Reactor Experiment in the near future, and the second core for the Hallam Nuclear Power Facility is expected to be fabricated of UC.

Each fuel assembly consists of a cluster of 19 fuel rods, an intermediate hanger rod, and a shield plug (Figure 5). The assembly hangs in the process channel, and is supported by the top shield which serves as the loading face.

Expanded metal spacers, located every 12 in. along the length of the fuel rods, separate the individual rods and provide lateral support. Three equally spaced wires tie the metal spacers together and prevent them from sliding out of position. A support ring is used at the top and a spacer ring at the bottom of the fuel-rod cluster. Each rod is free to expand downward independently. A guide at the bottom aligns the element during entry into the process channel. A hot-cell disconnect is provided at the top and bottom of the fuel rods to allow for easy disassembly of the 19 rods for spent-fuel reprocessing.

Fuel rods consist of 0.500 -in.-diam UC slugs, sheathed in 0.520-in.-ID, 0.010-in.-thick-wall, stainless steel jackets. The rods are about $14 \mathrm{ft}$ long with the lower $12 \mathrm{ft}$ containing the fuel slugs and the remaining $2 \mathrm{ft}$ providing space for fission-gas release. A sodium bond is used between the UC slugs and the jacket. End caps welded to the jackets seal the UC slugs and sodium under an inert gas.

The intermediate hanger rod that attaches the fuel cluster to the shield plug is of $3 / 4$-in. diam with disconnect fittings welded at top and bottom. A seal ring is welded to the hanger rod to force most of the coolant flow through the variable orifice in the calandria entry guide.

Disconnects are provided between the fuel cluster and hanger rod, and between hanger rod and shield plug. This arrangement permits the fuel handling cask to divide the fuel element (overall length, 41 ft 7 in.) into three segments, thereby reducing the height of the handling cask and providing a means of transferring the spent-fuel clusters without the need for on-site hot-cell facilities. Since the fuel element when fully assembled is always inside the close-fitting orifice tube and process tube, a simple sliding tongueand-groove disconnect is employed.
Each fuel element is suspended from a shield plug in the loading-face shield. The shield plug consists of a cylindrical steel shell, stepped at the mid-plane of the shield section for support and to minimize radiation streaming. Quad-ring silicon rubber seals are used to seal the shield plug to the orifice tube and loading-face shield. Thermal insulation is provided by filling the lower end of the plug with 12 in. of stainless steel wool. Six inches of steel shot (radiation shielding) is placed directly above the steel wool, and dense concrete fills the remaining space to floor level. This design has been evolved from SRE experience and represents a low-cost arrangement which meets shielding requirements.

An orifice tube extends from the floor level down through the loading-face shield into each of the calandria entry guides (Figure 6). This orifice tube serves three purposes: (a) acts as a guide when inserting and removing fuel elements; (b) provides a means of varying the coolant flow past the fuel elements by incorporating a variable orifice in the process channel; and (c) provides support for two thermocouple wires used to measure the outlet sodium temperature of each process channel. Orificing of coolant flow is accomplished by a rectangular opening in the orifice tube which is located vertically to match a triangular-shaped opening in the calandria entry guide. Effective orifice area or coolant flow is varied by rotating the orifice tube by means of a spanner wrench from the reactor floor.

Each orifice has a $31 / 2$-in. diam, has a 0.083 -in.thick wall, and is stepped at the midplane of the loading-face shield to provide support and to minimize radiation streaming. A silicon rubber quad-ring forms a seal between the shield plug and its sleeve in the loading face to protect the reactor atmosphere. The orifice tube and shield plug are held down by a plug bolted to the loading-face shield. A silicon rubber seal between the holddown plug and the loading-face shield provides a backup seal on the reactor atmosphere.

The fuel handling system and maintenance-pit area consist of the fuel-transfer cask, spent-fuel storage area, new-fuel storage racks, preheat cell, and shipping casks. A gantry crane, which moves on rails embedded in the reactor floor, supports and positions the cask.

\section{CONTROL ROD AND DRIVE MECHANISM}

Eighteen combination shim and safety rods are required to control the reactivity changes associated with temperature, poisons, and fuel depletion. Drive mechanisms are of the ball-latch safety-rod type now under development. ${ }^{5}$ In this rod, the absorber (poison) element is supported by two wire ropes which pass through two small tubes in the shield plug. The ropes connect to a latch which engages the absorber element (Figure 7). The latch remains attached when 


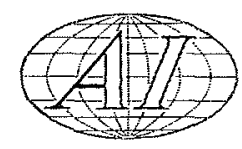

both ropes are raised or lowered together. Lowering one rope about 2 in. with respect to the other tilts the latch and disengages the absorber element. The rod then drops into the core under the force of gravity and inserts negative reactivity, thereby effecting a reactor scram. Snubbing is accomplished by a sleeve on the top of the absorber element plunging into an annulus filled with granular material. This annulus is built into the wall of the thimble.

The entire drive mechanism is located below the reactor loading face in order to facilitate refueling. A helium atmosphere is maintained within the thimble to aid in the removal of heat generated in the absorber element (when partially inserted) to the sodium coolant in the core.

\section{NEUTRON SOURCE}

A startup neutron source is located in a thimble near the core center. The unit consists of an antimony capsule centered within a series of beryllium cylinders. The beryllium cylinders are suspended on a hanger rod from a plug in the loading-face shield. The gamma source (antimony capsule) is installed through the beryllium hanger rod to permit replacement if necessary. Sufficient antimony tetroxide $\left(\mathrm{Sb}_{2} \mathrm{O}_{4}\right)$ is sealed in the stainless steel tube of the gamma source capsule to assure an adequate neutron flux for reactor startup. Before installation in the reactor, the antimony is activated to the desired level in another reactor.

\section{REACTOR HEAT TRANSFER}

In thermal performance calculations for the reactor, the following assumptions and limitations are used:

(a) Axial power distribution can be represented by a chopped cosine curve.

(b) Radial power distribution can be represented by a $J_{0}$, Bessel function.

(c) Coolant flow is throttled in each coolant channel to obtain a constant outlet temperature.

(d) Heat generated in the fuel rod is transmitted to the coolant in a radial direction only.

(e) Volumetric heat source for each fuel rod is constant in a radial directión.

(f) Thermal conductivity and specific heat do not vary over the temperature ranges considered.

(g) A limiting fuel temperature of $2250^{\circ} \mathrm{F}$ for UC fuel. This results in a temperature gradient from center to carbide surface of approximately $1200^{\circ} \mathrm{F}$ in $1 / 4$ in., approximately $1 / 4$ of the gradient used in a sintered $\mathrm{UO}_{2}$ element. The temperature limit on $\mathrm{UC}$ is not yet established.

(h) A maximum pressure-drop limitation across the fuel elements of 25 psi, excluding end losses.
A peak fuel temperature of $2250^{\circ} \mathrm{F}$ is obtained in the outer ring of rods of the center fuel element $\sim 1.2 \mathrm{ft}$ above the reactor-core centerline based on the following disadvantage factors:

$\begin{array}{ll}\text { Radial flux peaking } & 1.60 \\ \text { Axial flux peaking } & 1.38 \\ \text { Element flux peaking } & 1.18 \\ \text { Uncertainty flux peaking } & 1.10 \\ \text { Peak-to-average power ratio } & 2.87 \\ \text { Variation in thermal conductivity } & 1.10 \\ \text { Peak-to-average temperature } & 3.15 \\ \quad \text { gradient in fuel } & \\ \text { Average heat flux } & 425,000 \mathrm{Btu} / \mathrm{hr}^{-\mathrm{ft}^{2}} \\ \text { Maximum heat flux } & 1,240,000 \mathrm{Btu} / \mathrm{hr}^{2} \mathrm{ft}^{2}\end{array}$

\section{REACTOR PHYSICS}

As described in section II-A, the core of this reactor differs from that of the SRE and HNPF in that the moderator logs are not individually canned. There are advantages as well as disadvantages to this arrangement. It greatly reduces the amounts of graphite-sodium barrier and of sodium from the core, resulting in less parasitic capture of neutrons. Manufacturing tolerances are also somewhat relaxed. However, graphite moderator temperatures are high because of the poor thermal coupling to the sodium coolant. Heat generated in the graphite must be removed by conduction across a gas gap around the process tube, unless a separate graphite-cooling system is used.

The high graphite temperature results in a thermal neutron group with a most probable energy of about $0.13 \mathrm{ev}$. The neutron yield, eta, is low for both $\mathrm{U}^{23 \bar{n}}$ and $\mathrm{Pu}^{23.3}$ in this neutron spectrum, with the result that the fissile material is used with somewhat less efficiency than would be the case with a lower neutron temperature.

In spite of the high neutron temperature and relatively low conversion ratio, the fuel-cycle costs for the reactor are very attractive under exposure conditions discussed in section II-A-2.

The hot, poisoned, new core can be made critical with a fuel enrichment of about 1.6 at. $\% \mathrm{U}^{233}$; the corresponding initial conversion ratio is about 0.6 . However, burnup requirements increase the initial enrichment to 2.7 at. $\% \mathrm{U}^{235}$. With this enrichment, the initial value of $k_{\text {err }}$ at operating temperatures, with equilibrium xenon and samarium poisoning, is 1.127. The initial conversion ratio under these conditions is 0.52 . A neutron balance for the new core appears in Table II. Starting with an enrichment of 2.7 at. $\% \mathrm{U}^{235}$, the fuel can be operated to an average exposure of 17,100 Mwd/MTU before being limited by reactivity considerations. At that time, the enrich- 
ment is 1.16 at. \% $\mathrm{U}^{2: 5}$. Irradiated fuel will contain 6.75 of $\mathrm{Pu}$ per $\mathrm{kg}$ of $\mathrm{U}$.

Nuclear calculations were made using a two-group approximation. For the thermal group, a neutron temperature of $1250^{\circ} \mathrm{C}(0.131 \mathrm{ev})$ was used, based on the average moderator (graphite) temperature in the core.
Thermal cross sections are volume and flux weighted in computing group constants. Weighting is accomplished by successive applications of two-cell calculations. The first of these obtains the average properties of a cell typical of the whole core ( 151 fuel channels and 19 control or source channels). Steps involved are described in the following paragraphs.

\section{TABLE II}

NEUTRON BALANCE FOR 255-MWE ADVANCED SODIUM GRAPHITE REACTOR

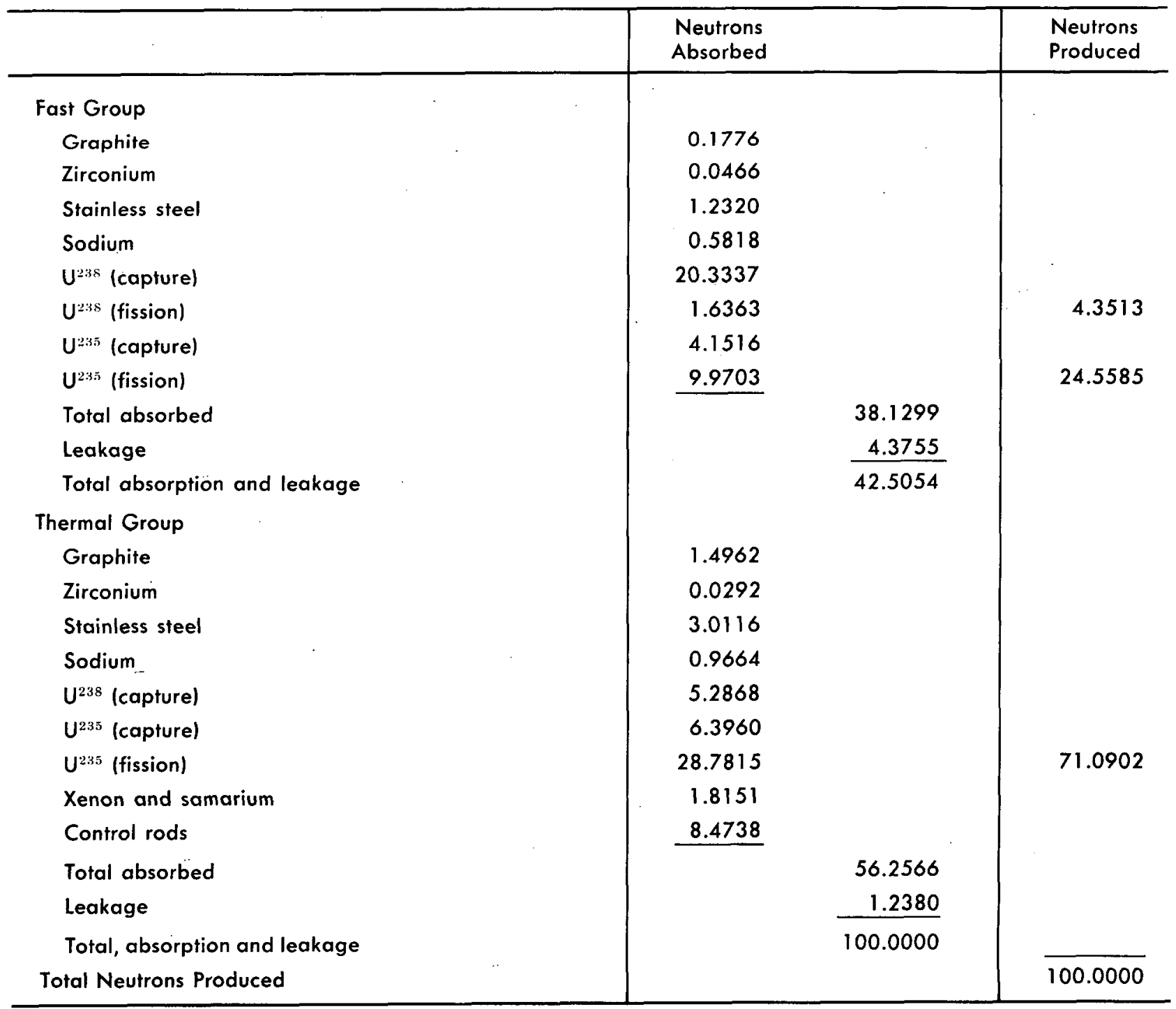

Basis: Enrichment $=2.7$ at. $\% U^{235}$; equilibrium $X e$ and $S m$; core at operating temperatures; $K_{e i f}=1.123$ without control rods; initial conversion ratio $=0.52$. 


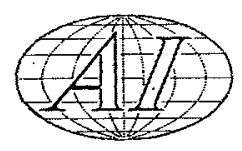

In the first step, the fuel cell is broken into three cylindrical regions. The first of these consists of all the materials inside the process tube, with a disadvantage factor weighting the fuel-material cross sections to take into account the difference between the average flux within the fuel rod and the flux at the edge of the fuel rod. Region 2 consists of the stainless steel process tube, the zirconium liner, and the void between them. Region 3 consists of the graphite moderator $\log$, converted from a hexagon to a cylinder of equivalent area and inner diameter. Each of these regions is homogenized; average constants are calculated for each region; and region fluxes are obtained by the $P_{3}$ approximation. Average constants are then computed for the cell by flux and volume weighting the region cross sections.

In the second step, a four-region cell is formed. Region 1 consists of a void, to correspond to the inside of a control-channel process tube with the control rod withdrawn. The second region consists of the process tube and liner, and the third region of the graphite log surrounding the process tube. The fourth region consists of a material that has the average constants of a fuel cell, as previously computed. Radius of this region is taken so as to give the same ratio of fuel to control cells as exist in the core $(151 / 19)$. Average region fluxes are then obtained, and the cross sections of the four regions are flux- and volume-weighted to give thermal constants for a cell typical of the core.

Fast-group constants are obtained using the IBM 709 MUFT IV code. ${ }^{6}$ Using these results, criticality calculations are performed using the IBM 704 WANDA Code. ${ }^{\tau}$ Initial conversion ratio is calculated from a compatible two-group approximation which takes account of fast fissions in $\mathrm{U}^{235}$. Using the results of the above work, burnout studies are conducted using the IBM 704 CANDLE Code. ${ }^{8}$

\section{B. REACTOR STRUCTURE}

The reactor structure includes the following components:

(1) Neutron shield

(2) Reactor vessel, EM pumps, and heat exchangers

(3) Heat exchanger and pump removal plugs

(4) Containment vessel and insulation

(5) Support structure

(6) Loading face shield.

All of these components are located in the reactor cavity below floor level (Figures 8 and 9). Side walls of the reactor cavity support the loading-face shield, heat-exchanger removal plugs, and pump removal plugs, all of which fill the openings and seal the cavity from the reactor room. Surfaces of the loading-face shield and removal plugs are on the same level and form a portion of the reactor room floor. A radial neutron shield around the calandria core shields the secondary sodium in the intermediate heat exchangers from neutrons.

Primary sodium is completely contained within the reactor vessel. Three intermediate heat exchangers, equally spaced in the annulus between the neutron shield and the reactor vessel wall, transfer heat from the reactor to the nonradioactive secondary sodium. Nine EM pumps, three per heat exchanger, circulate the primary sodium up through the calandria core. Sodium from the calandria core (at $1200^{\circ} \mathrm{F}$ ) enters a pool above the core and flows over the neutronshield wall, down past the heat exchangers where the primary sodium transfers its heat to the secondary sodium. Sodium leaves the heat exchangers at $650^{\circ} \mathrm{F}$ and flows into the suction side of the EM pumps. It is then discharged through nine pipes into the inlet plenum below the calandria core.

Support for the calandria core, neutron shield, reactor vessel, and containment vessel is provided by the reactor support structure and concrete foundation. Accurate positioning of the core and shield is accomplished by keying them to the reactor vessel. Thermal insulation surrounds the containment vessel.

\section{NEUTRON SHIELD}

The neutron shield around the calandria vessel is contained in an annular tank of 17 -ft 2 -in. ID, $21-\mathrm{ft}$ $\mathrm{OD}, 31-\mathrm{ft}$ high, and with wall thickness of $3 / 4$ in. (Figure 10). Nine slots in the bottom, 21- by 18 -in., provide passage for the coolant pipes to the inlet plenum. The bottom of the tank is $3 / 4$ in. thick, and the top is of 16-gage material to allow for differential expansion between the inner and outer walls. Tank material is stainless steel and of all-welded construction. This tank is filled with 10 in. of carbon steel adjacent to the inside wall followed by $81 / 2$ in. of titanium hydride aggregate and by $3 / 4$ in. of $1 \%$ boron steel. These shield components extend the height of the annular tank. The remaining voids are filled with sodium to transfer heat generated in the shielding materials to the walls of the annular tank.

The carbon steel shield is made from 5-in.-thick plates suitably formed to fit between $12 \mathrm{~T}$-shaped support columns. To prevent neutron streaming along the columns, steps are provided at the support column, and plate heights are varied so that the horizontal joints are staggered.

The iron in the neutron shield serves to attenuate neutrons of energies greater than $1 \mathrm{Mev}$ by inelastic scattering and to absorb thermal neutrons from the core and reflector. Titanium hydride is used to moderate epithermal neutrons, and the boron steel absorbs the neutrons thermalized by the titanium hydride. Shielding requirements are based on a maximum dose rate of $7.5 \mathrm{mr} / \mathrm{hr} 3 \mathrm{ft}$ from the secondary sodium piping. 


\section{REACTOR VESSEL ASSEMBLY}

\section{a. Reactor Vessel}

The stainless steel reactor vessel which contains the calandria vessel, neutron shield, intermediate heat exchangers, and the nonelectrical EM-pump structure is of 27-ft 6-in. ID, $38 \mathrm{ft}$ high, and of 1 -in. thick wall (Figure 11).

At the top, a bellows seals the reactor vessel to the cavity liner to prevent sodium vapor and the nitrogen atmosphere from escaping. It also allows for thermal expansion and contraction of the reactor vessel. The bellows is fabricated from 15-gage type 347 stainless steel, is $1 \mathrm{ft} 10 \mathrm{in}$. long, and contains 11 convolutions. A guard surrounds the outside of the bellows to prevent damage during installation or removal of the EM pump coil structure.

Support for the nine EM pumps is provided by stainless steel frames welded to the walls of the reactor vessel. These supports also serve as guides so that pumps may be installed or removed by workers at the reactor floor level.

A pump discharge plenum, located directly under each pump, is fabricated by welding a formed $1 / 2$-in.thick shell to the inside of the reactor shell wall and bottom head (see Figure 12). Sixteen 1/2-in.-diam rods tie the formed shell and reactor shell together. A 12-in. outlet nozzle directs sodium flow from the pump discharge plenum to the inlet plenum under the calandria. To permit installation or removal of the calandria vessel, a movable sleeve is used between the pump and calandria nozzles. To allow for possible misalignment between the calandria and pump, a ball joint is provided at both ends of the sleeve.

\section{b. Electromagnetic Pump}

Nine primary sodium pumps, designed to operate on 3-phase, 220-volt, 15-cycle current, pump sodium at $650^{\circ} \mathrm{F}$ against a head of $40 \mathrm{psi}$ at a rate of 3400 gpm (Figures 12, 13, and 14).

Each pump consists of a laminated silicon steel core on the inside of the reactor vessel wall and a laminated silicon steel core and coil structure mounted directly opposite on the outside of the reactor vessel wall. Similar pumps are under active development. ${ }^{9}$

The pump throat formed by the reactor vessel and the internal laminated core is $4 \mathrm{ft}$ wide by $5 \mathrm{ft}$ high with $3 / 4$-in. annular gap. Each lamination is $2 \frac{1}{4}$ in. wide by $5 \mathrm{ft}$ long and 0.014 in. thick. A 4-ft.-wide stack of these laminations are sealed against sodium by a welded, 16-gage stainless steel jacket.

A pump inlet plenum is provided at the suction side of the pump to channel the sodium flow from the heat exchanger into the pump throat. This plenum has two $81 / 2$ in. diam nozzles which mate with the heat exchanger exit nozzles (shell side of exchanger). These nozzles are fastened to the pump plenuri by a labyrinth-type seal to allow for a possible misalign- ment of the pump inlet plenum and the heat exchanger, and also to permit movement caused by thermal expansion. An O-ring-type seal between the internal laminated core and reactor vessel is formed from 0.75-in.-OD by 0.010 -in.-thick-wall stainless steel tube.

The external laminated core is slotted to receive 24 anodized aluminum windings. Twelve bus bars mounted on post-type insulators below the core structure connect to the windings through six spring-type mechanical disconnects. Frequency converters installed at reactor floor level supply 15-cps electrical energy to the pump windings.

\section{c. Heat Exchanger}

Three single-pass, counterflow heat exchangers transfer heat from the primary sodium system to the secondary sodium system (Figure 15). Primary sodium $\left(1200^{\circ} \mathrm{F}\right)$ enters the shell side of each heat exchanger through 11 calibrated orifices sized to provide a 20 -in. head differential of sodium when operating at full flow. Six exit nozzles located at the bottom of each heat exchanger direct the primary sodium to three EM pumps operating in parallel. Primary sodium flow is determined by measuring differences in level across the orifices.

Secondary sodium enters the bottom of the heat exchanger through a header and flows upward through 750 tubes of 1 -in. diam, to a header at the top. Both top and bottom secondary flow headers are welded to 18-in.-diam stainless steel pipes which extend up into the shield plug above the heat exchanger.

\section{HEAT EXCHANGER AND PUMP REMOVAL PLUGS}

Each of the three heat exchanger plugs is removable and consists of two sections (Figure 16). The bottom section includes the heat exchanger, bottom shield plug, and gas seal. That portion of the secondary sodium piping which extends from the heat exchanger headers up into the bottom shield plug is covered with $4 \frac{1}{2}$ in. of insulation, and is enclosed by a 29 -in.-diam guard pipe. The top shield section covers the portion of the heat-exchanger piping which extends above the bottom section and carries the sodium into the secondary piping galleries.

Both the top and bottom sections are made of dense concrete encased in type 405 stainless steel forms. Steps are suitably placed to prevent radiation streaming and to provide a ledge for support. Cooling coils embedded in lead remove heat generated in the concrete or conducted across the thermal insulation.

The laminated core and coil structure of the individual EM pumps is accessible through stepped openings in the biological shielding which covers the reactor area (Figure 1). These openings are filled by plugs similar in construction to the heat-exchanger plugs. 


\section{CONTAINMENT VESSEL}

A containment vessel which encloses the reactor vessel has a $31-\mathrm{ft}$ diam at the bottom and 33-ft diam at the top (Figure 17). Vessel height, including the bellows assembly, is $38 \mathrm{ft}$ and the sides and bottom are $1 / 2-i n$. thick. The vessel material is chromiummolybdenum steel.

At the top, a bellows seals the containment vessel to the cavity liner to maintain a nitrogen atmosphere and provides for thermal expansion. The bellows is fabricated from 15-gage type 347 stainless steel, is $1 \mathrm{ft} 10 \mathrm{in}$. deep and contains 11 convolutions.

Ballast tanks are located in the annular space between reactor vessel and containment vessel. If leaks should occur in the reactor vessel, the sodium is retained by the containment vessel at the level (in the core) necessary to assure natural circulation to remove decay heat from the fuel. The carbon steel ballast tanks are filled with rock ballast and sealed.

Surrounding and attached to the walls of the containment vessel is $1 \mathrm{ft}$ of insulation. The heat generated in the concrete and any conducted across the insulation is removed by cooling coils embedded in the concrete. Cadmium sheet, 0.020-in.-thick, lines the inside surface of the concrete shield and is used to reduce back scatter of neutrons thermalized in the concrete.

\section{SUPPORT STRUCTURE}

A support structure is provided for the containment vessel which in turn supports the reactor vessel and calandria vessel. This structure consists of forty eight 16-in.-wide flange structural steel beams positioned in a radial pattern beneath the calandria vessel. Vertical slots cut in the beams allow for differential expansion between the concrete and containment vessel.

\section{LOADING-FACE SHIELD}

Located above the reactor core is the loading-face shield (Figure 18). It is a cylindrical plug, $6 \mathrm{ft} 6$ in. thick and with $17 \mathrm{ft} 8 \mathrm{in}$. diam at the top surface, stepped down to $17 \mathrm{ft} 1 \mathrm{in}$. diam at the bottom. This shield plug is made of dense concrete encased in a form of type 405 stainless steel. The bottom surface of the form is 1 -in. thick, while the sides are $3 / 4-i n$. thick. Above the bottom surface is a $11 / 2$ in. thick layer of lead in which cooling coils are embedded (Figure 19). Thermal insulation, consisting of 12 horizontal stainless steel sheets, $1 / 32$-in. thick and spaced 1 in. apart, is suspended from the bottom surface of the shield plug.

A seal of welded stainless steel is provided between the plug and the upper cavity liner to maintain a nitrogen atmosphere over the sodium and to prevent the escape of radioactive gases from the core. If plug removal becomes necessary the seal may be cut and replaced.

The top shield also serves as the reactor fuel loading face with 187 openings located above the 187 process channels in the calandria vessel. Ten additional openings are provided for sodium-level indicators and neutron. instrumentation. Stainless steel sleeves which form the openings for all fuel elements, the neutron source, and instrumentation are 5 in. in diam at the top stepped to $33 / 4$ in. at the bottom. The 18 control-rod positions are 7 -in. in diam at the top, stepped to $43 / 16$ in. at the bottom.

A stepped orifice tube and shield plug fit into each fuel-element opening and control-rod thimbles fit the control-rod openings. Silicon rubber quad-rings form a gas seal between the loading-face shield and the various plugs and thimbles.

\section{SECONDARY SODIUM HEAT TRANSFER SYSTEM}

\section{A. GENERAL}

The nonradioactive secondary system is divided into three parallel loops (Figures 20 and 22). In each loop the sodium coolant is pumped from the intermediate heat exchanger to one steam generator. A variable-speed EM pump in each loop provides flow control to compensate for load changes from the turbine. In case of reactor scram or malfunction of a single loop, a throttling valve is used to reduce or shut-off sodium circulation. Electric heaters are installed on all sodium piping and equipment to preheat the system before admitting sodium. Nitrogen connections are provided to purge air from the system and to maintain an inert atmosphere in the expansion tanks.

\section{B. STEAM GENERATOR}

Three steam generators, one in each heat-transfer loop, are designed to generate a total of $1.835 \times 10^{\circ}$. $\mathrm{lb} / \mathrm{hr}$ of steam at $2450 \mathrm{psig}, 1050^{\circ} \mathrm{F}$. The steam is expanded through the high-pressure turbine, and about $82.2 \%$ of the throttle flow is then delivered to reheaters, where the steam is resuperheated to $1000^{\circ} \mathrm{F}$ at 504 psig.

The total sodium flow through each loop is $4.2 \times 10^{i} \cdot \mathrm{lb} / \mathrm{hr}$.

Steam-generator construction is of the oncethrough, monotube type, with steam and water on the tube side and sodium on the shell side. Each steam generator consists of a bank of three units 
which are manifolded in parallel and which supply superheated steam as required to the turbine throttle. The three liquid-metal reheaters, one operating with each bank steam-generator units, are in parallel flow with the steam generators on the sodium side of the unit.

Sodium coolant enters the reheater unit at $1150^{\circ} \mathrm{F}$ and leaves at $850^{\circ} \mathrm{F}$ to join the main sodium stream approximately at the evaporator-superheater junction of the steam generator.

Feedwater at $540^{\circ} \mathrm{F}$ passes through the economizer, evaporator, and superheater sections of the steam generator to produce steam at the above stated conditions.

A sodium relief system consisting of rupture discs is located on the steam generator and reheater shells, to prevent overpressurization of the secondary sodium system in event of a steam or water leak into the sodium system.

The steam generators and reheaters are of allwelded construction and fabricated of $21 / 4 \% \mathrm{Cr}-$ $1 \%$ Mo steel.

A heat balance diagram is presented in Figure 21.

\section{SECONDARY SODIUM PUMPS}

Three secondary sodium EM pumps, one in each loop, circulate sodium from the tube side of the intermediate heat exchangers to the steam generators. Each secondary pump is rated at $10,200 \mathrm{gpm}$ at $600^{\circ} \mathrm{F}$ against a total static head of 40 psi. A helicalrotor EM pump now under development at Atomics International will be used. This pump consists of a magnetic-core rotor in the form of a helix mounted vertically inside a hollow cylindrical sodium duct. Collection headers at each end connect the duct to the piping nozzles. Field intensity in the helical rotor is established by two dc windings, one located above and the other below the duct header. A steel casing which encloses the pump duct and field windings provides a return path for the magnetic field. A 3-phase, 60-cycle, 4160-v induction motor drives the helical rotor at constant speed, and flow control is established by varying excitation to the dc windings.

\section{VALVES}

A throttle valve is provided in each secondary sodium loop between the intermediate heat exchanger and pump to reduce or stop sodium flow in case of reactor scram or malfunction of one loop. All valves are power actuated with manual override. A watercooled freeze seal is provided between the valve stem and core.

\section{E. EXPANSION TANKS}

Each expansion tank is sized to accommodate sodium volume changes from cold startup to operat- ing temperatures and provides a free surface for eliminating entrained gas. By means of the inert-gas atmosphere in the expansion tank, the secondary loop pressure is maintained at a higher level than that of the primary system pressure to insure that if any leakage should occur across the intermediate heat exchanger, it would be from the nonradioactive secondary system to the radioactive primary system.

\section{F. SECONDARY SODIUM PIPING}

All piping is 18 -in., $1 / 4$-in.-wall, type 304 stainless steel. Each joint is welded using a heliarc root pass with an inert-gas backing and a shielded arc filler.

The piping and all associated equipment are heated by electrical heaters capable of producing and maintaining a temperature of $350^{\circ} \mathrm{F}$. This temperature is well above the melting point of sodium $\left(208^{\circ} \mathrm{F}\right)$. Views of the layout of the secondary-system piping appear in Figures 22 and 23.

\section{G. SODIUM SERVICE SYSTEM}

Service facilities are provided to fill, drain, and flush the primary and secondary sodium systems, and for purification of the sodium (Figure 24). This system consists of tank car and drum melt stations for new sodium, primary and secondary fill tanks, EM service pumps, plugging-meter and cold-trap equipment for sodium purification, reactor drain pumps, calandria pump and storage tank, vapor traps, freeze traps, and associated piping and instrumentation.

\section{H. FILLING}

Prior to filling with sodium, the system is purged with nitrogen and preheated to $350^{\circ} \mathrm{F}$. Two sodium melt stations are provided for system filling. One station will accommodate a tank car in which sodium is received for the initial filling operation. Approximately 20 tank cars, each containing 80,000 lb of sodium, are required to fill the primary and secondary systems. The tank-car sodium is melted by a hot-oil circulating system and transferred by nitrogen pressure through filters from the tank car to either primary- or secondary-system fill tanks. Melting and transferring sodium from one tank car is accomplished in about $12 \mathrm{hr}$.

The other melt station will accommodate two 55-gal drums and is used to supply sodium for system makeup. Electrical heaters melt the sodium which flows by gravity from the drums to the sodium transfer tank. From here it is transferred by nitrogen pressure through filters to either set of fill tanks. A transfer tank is necessary since the sodium drums are not designed to withstand the 30-psig gas pressure necessary to transfer the sodium through the filters and to the fill tanks. Both melt stations, sodium filters, and secondary fill tanks are located above grade in unshielded areas. Primary fill tanks are located in a shielded concrete vault. 


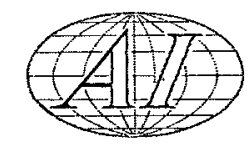

Reactor sodium (primary system) is transferred from four 37,000 -gal primary fill tanks. Gravity flow followed by pumping is used to fill the reactor vessel to a predetermined level. Two primary cold traps and a plugging meter are manifolded to the fill system so that oxides can be removed from the sodium before it is admitted to the reactor vessel. High points in the cold-trap piping are vented through freeze traps to prevent sodium from entering the vent and nitrogen systems. During the filling operation, gas escapes through the freeze trap to the vent system until sodium enters the trap and forms a solid plug which seals the vent line. When it is necessary to open the vent, frozen sodium is melted by electrical heaters. The reactor vessel and primary-system fill tanks share a common vent header. Water-cooled vapor traps are used to prevent sodium vapors from entering the vent system.

Two 37,000-gal secondary fill tanks are used to fill all three secondary loops to predetermined expansion-tank levels. Nitrogen atmosphere is maintained over the free surfaces of the sodium in the expansion tanks at all times, and the tanks are vented to the atmosphere through individual vapor traps and relief valves.

Both the primary and secondary service systems contain 75-gal drain tanks located in their respective systems to permit complete drainage of piping.

\section{DRAINING}

Sodium may be drained from the reactor to the primary fill tanks by two reactor drain pumps. One pump takes suction from the calandria lower plenum, and the second draws from the bottom of the reactor vessel.

Using either the secondary service pump or nitrogen gas pressure applied at the expansion tanks, the secondary sodium system is drained into the secondary fill tanks. Drain lines are connected through manually operated valves from low points in each loop to the secondary service pump.

\section{J. SODIUM PURIFICATION}

Purification equipment in the sodium service system functions to remove sodium oxides from the sodium. Two primary and one secondary circulating cold-trap and plugging-meter assemblies are provided. Sodium enters the cold trap through the economizer section where it is precooled. The sodium is further cooled in a section containing wire mesh in which the oxides become insoluble and are filtered out. Purified sodium then flows across the economizer section where it is reheated and returned to the heattransfer system. The entire cold trap can be replaced when saturated with oxide.

Plugging meters are provided to indicate the oxide concentration. Sodium flows through an economizer, heater, cooler, plugging meter, a second heater, and back through the economizer. By controlling the cooling rate of the sodium, a temperature is reached at which the oxide precipitates and begins to plug the orifice. Oxide concentration is determined by comparing the plugging temperature with a plot of saturation temperature for sodium oxide in sodium. Normally, a small flow of sodium is maintained through the plugging-meter loop when not used for oxide measurements.

Two cold-trap units are furnished for the primary system so that one unit can be in operation while the other is being serviced. Each primary unit is located in an individual concrete vault, making one accessible while the other is operating. The cold-trap and plugging-meter assembly in the secondary system is located above grade in an unshielded area.

Sodium-service piping is arranged so that sodium from either the fill tanks or the individual loops can be purified. Prior to the initial filling of the systems, the sodium in the fill tanks is purified by transferring the sodium from the fill tank through a cold trap and back to the same fill tank. This system can also be used before introducing new sodium into the heattransfer systems for makeup, if required. Once the heat-transfer system is filled, cold trapping is done by tapping a small sodium stream from the discharge side of a heat-transfer-system pump, sending it through a cold trap, and returning it to the heattransfer system on the suction side of the pump. Equipment now under development at AI will combine the cold trap with the sodium fill tank. This will eliminate the need for a separate purification system and for periodic cold-trap replacement.

\section{K. CALANDRIA SODIUM PUMPOUT SYSTEM}

In the event of minor leaks into the calandria vessel, sodium is pumped by an eductor to a 500-gal pumpout tank. A drain pump circulates sodium from this tank through the eductor where suction is established on the calandria vessel drain line. Some sodium is always maintained in the pumpout tank for priming the eductor and drain pump. A leak detector system automatically starts the pump to remove the leakage.

The magnitude of any leak is determined by periodically measuring the rate of change of the sodium level in the pumpout tank.

Due to the possibility of introducing carbon that may accumulate in the bottom of the calandria vessel, the sodium is retained in the pumpout tank, and is not normally returned to the primary system. However if a major leak should occur and the capacity of the pumpout tank is exceeded; excess sodium is drained by gravity to the service-system drain tank. 


\section{SODIUM PREHEATING SYSTEM}

Prior to admitting sodium, all sodium systems are preheated to $350^{\circ} \mathrm{F}$. This ensures that the liquid sodium admitted to the systems will remain molten and circulate freely to all pipes, tanks, and other related equipment. In addition, some equipment is continuously or intermittently heated during operation.

Resistance and transformer heating is used for all piping and components except the steam generators, which will be heated by steam, and the sodium tank car, which will utilize steam-heated oil. The steam will be supplied from an oil-fired steam generator.

Wherever practical, sodium piping is heated by passing an alternating current through the piping itself. A step-down transformer provides a high current at low voltage to the midpoints of the piping section to be heated. Current heats the pipe as it flows toward each end where the pipe is connected to the return circuit of the step-down transformer. All pipes heated in this manner are electrically insulated.

In areas where transformer heating is not practical, resistance heating units are employed. These heater units incorporate a U-bend tubular heater, reflector, thermal insulation, and outer steel jacket within a single section. Each heater is supported away from the pipe approximately in the center of a 1-in. annular space between the reflector and pipe. Normally for 2- and 3-in. pipe sizes a single heater is employed in one 180 degree annular section, with the other half-section identical except with no heater. In inaccessible areas both half-sections contain heaters, with the second heater installed and wired as a spare.

For 18-in. pipes, a three-section assembly is employed, with each section containing a heater. Similar prefabricated heater sections cover the piping elbows and tees. For valves and pumps fieldfabricated heater assemblies are used which are similar in construction to the resistance heaters installed on the pipes.

- Tubular heaters are employed for heating tanks and vessels. The heaters are attached to the tanks by means of clips on welded studs and are covered by a reflector, a layer of thermal insulation, and finally an outer steel jacket.

The reactor is heated by resistance-type heaters as shown on Figure 25. Straight tubular heaters are installed vertically and spaced equally around the outer surface of the containment vessel. Each heater is fastened to the surface of the containment vessel by means of clips on welded studs.

Tubular heaters are also installed on the structural steel beams comprising the reactor support structure. Two heaters are used on each support beam, one for normal service and the other as a spare. A reflector, fabricated from 16-gage sheet metal, is placed over each heater, and tack-welded to the beam flange and web prior to the placement of the concrete fill. Components within the reactor vessel are preheated by introducing controlled quantities of sodium into the bottom of the reactor vessel. Heat is conducted by the sodium from the vessel walls and bottom to the internal structure. After the primary system is filled with sodium, additional heat is supplied by operating the linear induction pumps.

Cold traps and the sodium heaters in the steam generator are heated with field-installed tubular heaters, similar in construction to the tank heaters. Freeze traps have factory-installed tubular heaters for use when it is necessary to melt the trapped sodium for normal service. Other components are provided with resistance heaters as required for their proper functional operation. The electrical heating system is automatically controlled by means of scanning-typerecorder controllers located in the control room. Each controller will incorporate an overtemperature alarm connected to an annunciator.

Three scanner-controller units (one 12-point and two 150-point units) are provided. Thermocouples are installed on all tanks, vessels, pumps, valves, and other components, and at frequent intervals on the pipes, with their leads extending into a central panel located in the control room and connected to the thermocouple scanners. These controllers contain pilot contacts which close when the sensed temperature is below the set point and open when the temperature is above the set point, and which automatically turn the heater on and off as necessary to maintain temperature.

Heater junction centers are located in the secondary loop area, in the fill tank area, and in the reactor area. All junction centers are accessible during normal operations.

A $480 / 277-v, 4-w i r e$, grounded-neutral system is employed throughout, with all heaters rated for $480-\mathrm{v}$ operation. Normally heaters are operated at a reduced voltage of 277 , resulting in a two-thirds reduction in wattage for added heat reliability.

\section{REACTOR AUXILIARY SYSTEMS}

\section{A. WATER COOLING SYSTEM}

Treated cooling water at $85^{\circ} \mathrm{F}$ and $125 \mathrm{psig}$ is pumped in a closed system by three half-capacity cooling-water pumps, with one reduced capacity cooling water-pump provided for emergency service (Figure 26). Station cooling-water exchangers which remove heat from the cooling-water system are supplied with river water by three half-capacity auxiliary 
pumps, with one reduced-capacity pump provided for emergency service. Reactor equipment and structure exposed to nuclear radiations is cooled by a separate circuit in which disposable ion exchangers are provided to remove activated impurities in the water.

Cooling water is provided for the following:

Service-air-compressor jacket and aftercooler Instrument air compressor jackets, aftercooler, and dryer

Hydrogen-seal-oil cooler

Hydrogen cooler

Turbine-lube-oil cooler

Feedwater-pump-oil cooler

Condenser vacuum pump

Miscellaneous sample coolers

Reactor concrete shields

Primary service cells and pipe tunnels

Wash cell and vent condenser
Fuel storage area

Primary and secondary cold traps

Secondary system throttling valves

Plugging-meter coolers

Miscellaneous freeze and vapor traps.

The water circuit used for cooling items which are exposed to nuclear radiation consists of two mixedbed, disposable-type ion exchangers, two centrifugal pumps, a chemical treatment tank, two water-towater shell-and-tube heat exchangers, piping, and instrumentation. All piping, pumps, tanks, and heat exchangers are made of carbon steel, and a corrosion inhibitor is used to protect the carbon steel piping system. To reduce activity in this cooling system, approximately $10 \%$ of the flow is bypassed through a disposable ion exchanger to remove impurities exposed to nuclear radiations.

Heat loads for the reactor portion of the station are given in Table III.

TABLE III

WATER-SYSTEM COOLING LOADS FOR REACTOR COMPONENTS

\begin{tabular}{|c|c|c|}
\hline & \multicolumn{2}{|c|}{$\begin{array}{l}\text { Cooling Load } \\
\text { (Btu/hr) }\end{array}$} \\
\hline \multicolumn{3}{|l|}{ Spent Fuel Storage } \\
\hline Normal & & $6,400,000$ \\
\hline Maximum & & $(7,800,000)$ \\
\hline \multicolumn{3}{|l|}{ Reactor Top Shield } \\
\hline Loading face shield & & 120,000 \\
\hline \multicolumn{3}{|l|}{ Heat exchanger shield plugs } \\
\hline Each plug & 30,900 & \\
\hline Total for 3 required & & 92,700 \\
\hline \multicolumn{3}{|l|}{ Primary pump shield plugs } \\
\hline Each plug & 6,400 & \\
\hline Total for 9 required & & 57,600 \\
\hline Reactor Side Shield & & $1,750,000$ \\
\hline Small-Component Wash Cell & & 235,000 \\
\hline Wash-Cell-Vent Condenser & & 20,000 \\
\hline Initial System Cleanup (each cold trap) & 360,000 & \\
\hline 2 Primary and 1 Secondary Operating (total) & & $(1,080,000)$ \\
\hline
\end{tabular}




\section{TABLE III (Continued)}

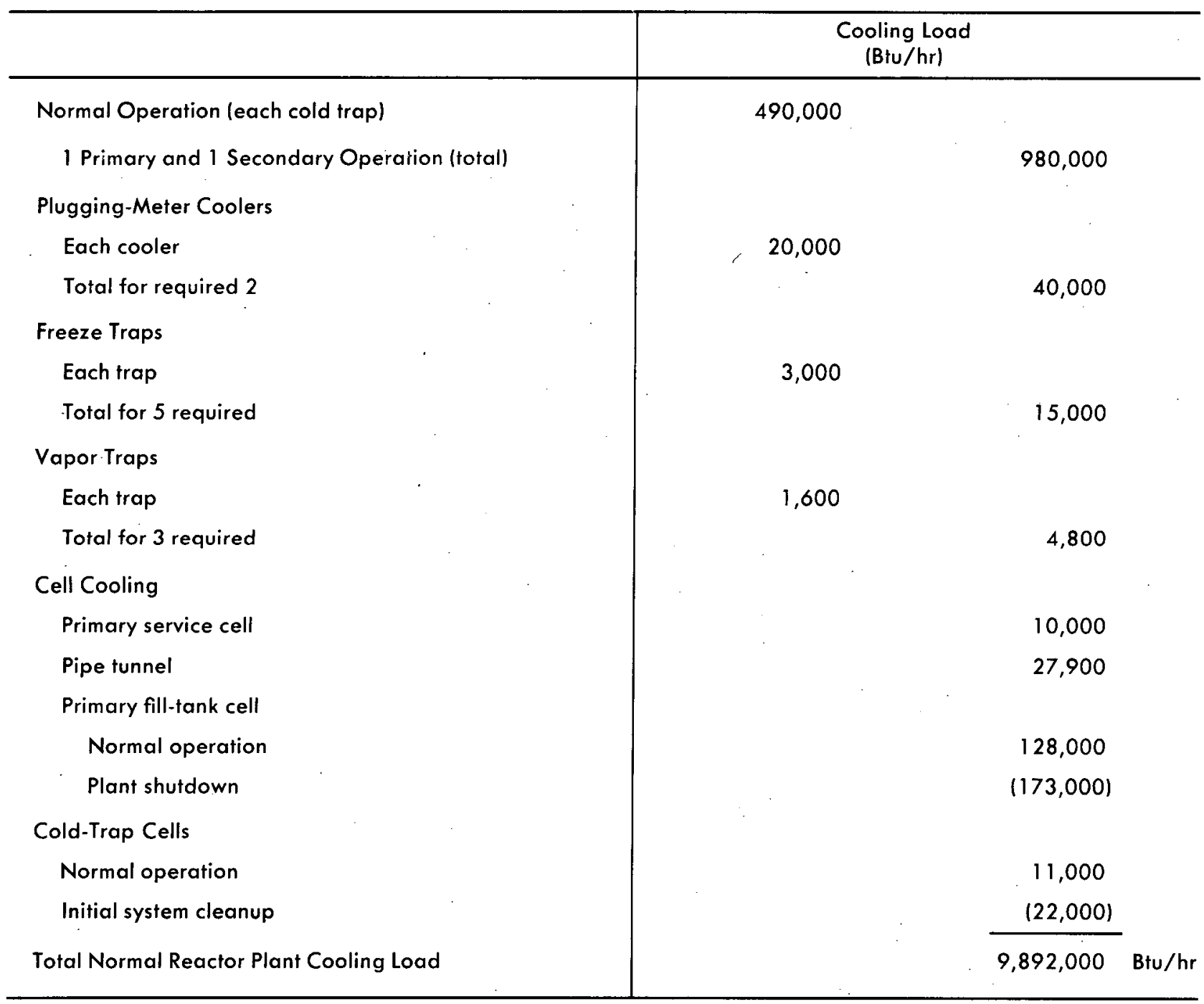

\section{B. INERT-GAS SYSTEM}

\section{NITROGEN SYSTEM}

Figure 27 illustrates the inert-gas system. A nitrogen system provides inert gas within the reactor container and at all points where a free surface of sodium exists. Current development programs are investigating the possibility of nitriding occurring at the sodium-nitrogen interface. ${ }^{10}$ Nitrogen also blankets the shielded cells which contain the primary sodium service systems. Helium is used in the control-safety rod thimbles and calandria vessel because of its superior heat-transfer characteristics.

The nitrogen system consists of two nitrogensupply trailer connections, a control unit, a desiccant absorber, a low-pressure storage tank, and a continuous oxygen analyzer. Each piping or equipment cell containing a nitrogen atmosphere has a pressure con- troller which operates both the inlet and outlet regulating valves. Dust filters are installed between the radioactive primary systems and the radioactive vent system.

Two nitrogen trailers are connected to the system control unit where the gas from one trailer is passed through one of two parallel pressure regulators, which reduces the pressure from 2400 to 55 psig. Whenever supply pressure drops below $55 \mathrm{psig}$, the operating regulator closes, and the reserve regulator opens to the standby trailer supply. A low-pressure alarm indicates when this action takes place. This arrangement permits replenishment without interrupting system operation.

Pressure controllers maintain constant pressures on the components which they supply. In general, the space above the top sodium pool is maintained at a 
pressure of 1 to 6 in. of water to ensure an inert atmosphere. The secondary system is maintained at 20 psig so that any sodium leakage is into the primary system to prevent contamination of the secondary system. Freeze seals on sodium valve stems are maintained at above atmospheric pressure to ensure an inert atmosphere between the freeze seal and the conventional packing. Nitrogen pressure in the reactor small-component wash cell and fuel packaging cell are the same as that in the reactor. The fuel cask carries its own nitrogen supply in bottles, with provisions for purging the gas interlock between the fuel cask and top shield, wash cell or packaging cell.

Primary fill-tank, service, and cold-trap cells are maintained at a pressure of 1 to 6 in. of water. To prevent overstressing of the cell liner, each cell containing primary sodium equipment is equipped with a relief valve which will open at 2 psig. An oxygen analyzer continuously records the oxygen content of the gas from each individual cell. All outlet nitrogen gas from the cells flows to the radioactive vent system.

During draining of the sodium heat-transfer loop, nitrogen is introduced at the high points in the system. The nitrogen flowrate into the system is determined by the sodium draining rate, which in turn is controlled by the sodium service pumps. Nitrogen is also connected to the cold-trap high points, to allow these components to be drained prior to removal.

Nitrogen service connections are supplied to the fuel-cask service area for use as required for special maintenance, etc.

\section{HELIUM SYSTEM}

The helium system consists of connections for helium supply bottles, a supply manifold, a control unit; a desiccant absorber, a low-pressure surge tank, and pressure regulators for the control-safety rod thimbles and calandria tank. Helium is supplied by a duplex manifold containing five 225-scf bottles per side, with one side on the line and the other on standby. The control unit reduces the pressure of the helium leaving the bottles and sends the gas to the storage tank. Two pressure controllers are connected in parallel with one controller used at a time to reduce the helium pressure to $50 \mathrm{psig}$. When the pressure supply drops to below 50 psig, the operating controller shuts off and the other controller opens to the unused bottles. A differential pressure regulator, controlled by the reactor vessel pressure regulator, equates the calandria vessel helium pressure to the pressure of nitrogen plus the pressure due to the hydrostatic head of sodium in the reactor. This pressure balance minimizes stresses across the calandria bellows. The control-safety rod thimbles are maintained at 15 psig so that, in the event of minor leaks, sodium does not enter the thimbles.
All inert-gas lines which are connected to radioactive systems or components, such as the reactor or the fuel handling system, are equipped with check valves to prevent radioactive gas from escaping to the atmosphere in the event of a rupture in an inertgas supply header. Throttle valves in the bypass lines around the regulators are used to control flow and pressure during purging. Rotameter-type flowmeters indicate flow. Relief valves to prevent overpressurization are connected to the radioactive vent system or to the atmosphere, depending on whether or not they release radioactive gases. Block valves are installed on all lines between the relief valves and the equipment to facilitate setting or removing relief valves.

\section{RADIOACTIVE VENT SYSTEM}

The radioactive vent system is designed to collect and monitor all radioactive gases for release through the plant effluent stack to the atmosphere, if the activity is below the maximum permissible concentration, or for storage in decay tanks and subsequent controlled release.

Figure 28 illustrates the radioactive vent system. It consists of four radiation monitors, a vent suction tank, two compressors, two decay tanks, and two absolute filters. Each of the four radiation monitors has a radiation indicator-controller which operates through a valve arrangement to divert the gas to either the effluent stack or to the decay tanks. One monitor controls the vents from the calandria pumpout tank, cold traps, liquid-waste storage tanks, cleaning cell, control rods, and portable waste containers. Another monitor controls the primary fill tank, neutron-shield wall, and reactor cavity vents. A third controls the vents from the sodium equipment cells, the inert gas relief system, the fuel packaging cell, and the intermediate-heat-exchanger storage cell. The fourth monitor controls the flow of gas from the vent decay tanks.

The vent suction tank, with a $200-\mathrm{ft}^{3}$ capacity, is constructed of carbon steel. It serves as a surge tank to reduce cycling of the compressors. Pressure controllers operate between -0.5 and 0.25 psig to actuate the vent compressors. High- and low-pressure alarms are provided.

Two nonlubricated, leak-tight, 25 scfm, 150-psig compressors are supplied, each equipped with an intercooler, a motor control timer, a sequence controller, and pressure switches. The two carbon steel decay tanks, which are connected in parallel, have a capacity of $1000 \mathrm{ft}^{3}$ at 150 psig. Two 50 -scfm filters are provided to remove particulate matter greater than 3 microns in size. If the pressure of the various contributing systems and components connected to the radioactive vent system increases beyond the control valve or relief settings, they open past one of the radiation monitors. 
When the activity level of the gas is below the maximum permissible concentration, the radiation monitor will cause the valve to open on the line that discharges to the effluent stack. Should the activity in the gas be greater than the maximum permissible concentration, a decay period and/or a controlled release to the atmosphere is required, and the valve directing the gas to the vent suction tank is opened. When the pressure builds up to 0.25 psig, a pressure controller on the tank starts the vent compressor which discharges the gas to one of the decay tanks. Reduction of the pressure in the vent suction tank to -0.5 psig in less than a preset time interval automatically opens a bypass valve and places the compressor on a time cycle, governed by the motor control timer. A high- or low-pressure alarm located on the vent suction tank gives warning of compressor failure to start or stop. If the gas gets too hot, a temperature-controlled valve on the water cooling system opens and water flows into the intercooler, reducing the gas temperature. A check valve on the discharge line prevents gas from reversing flow to the decay tank.

When the pressure in the decay tank approaches the compressor design discharge pressure of $150 \mathrm{psig}$, a high-pressure alarm is actuated. The tank is subsequently isolated and another placed in service. Samples of the gas are taken to establish a decay pattern and help identify the radioactivity. After a suitable decay period, the gas is released through the absolute filters to the stack at a rate compatible with the ventilation exhaust air such that the activity of the combined gases is below the maximum permissible concentration. A high-radiation-activity alarm located on the stack indicates approach to the maximum permissible concentration.

\section{RADIOACTIVE-LIQUID-WASTE SYSTEM}

A radioactive-liquid-waste system is provided to remove, store, and dispose of radioactive wastes originating in the equipment cleaning facilities and personnel decontamination room (Figure 29). Reactor components occasionally cleaned include the sodium- level thimbles, sodium temperature probes, and control-safety rod thimbles. Fuel is not normally cleaned, but occasionally a used fuel element may become contaminated with sodium oxide and would require cleaning before it is returned to the reactor. Saturated steam, supplied from the plant steam system, is admitted to the reactor small-component cleaning cell, producing a slow reaction with any residual sodium clinging to the component. To increase the rate of reaction, the moisture content of the steam is increased by mixing a controlled quantity of demineralized water with the steam. A 1-gpm volume control pump takes suction from a 50-gal demineralized water tank and discharges to a mixing nozzle located in the steam supply line. This pump is equipped with a variable-speed driver which is controlled by a steam flow controller. Steam quality is automatically maintained after manually adjusting the flow controller to the desired mixture setting.

Liquids in the cell drain directly to the transfer tank, while water vapors and gases evolved as a result of the water-sodium reaction, vent through a condenser to the radioactive vent system. In the vent condenser, water vapor is condensed and drained to the transfer tank. Any moisture that remains is removed from the wash cell by evacuating the cell using the vacuum pump in the radioactive vent system.

Sources of liquid wastes from the decontamination room and wash cell, and condensate drains from the radioactive vent system are collected in the transfer tank, where each batch of liquid waste is sampled and the type of disposal determined.

Once the activity of the waste is determined, the liquid is pumped from the transfer tank by means of a transfer jet which uses steam as motivating fluid. If activity is below the maximum permissible level, the liquid waste is pumped to the sanitary sewage leaching field. Waste of high activity is pumped directly to portable containers for off-site disposal or to storage tanks for holdup until the activity decays and permits ground or off-site disposal.

\section{FUEL HANDLING SYSTEM}

\section{A. GENERAL}

The fuel handling system provides for receipt, handling, storage, and shipment of new and irradiated fuel elements. Objectives of the fuel handling system are the following:

(1) To replace fuel elements semiannually during reactor shutdown. (The number of elements to be replaced will be determined by maximum permissible burnup of the fuel and the plant factor. Under the conditions for which the fuelcycle cost estimates of section $\mathrm{X}$ were made, namely 17,100-Mwd/MTU average burnup and an $80 \%$ plant factor, the average number of elements replaced semiannually is 49 .)

(2) To replace fuel elements without releasing radioactive contaminants into the reactor building and to limit radiation levels to personnel and the public to the maximum permissible levels as established by the National Bureau of Standards.

(3) To provide storage for fuel elements replaced during semiannual refueling, and, in addition, to provide storage for a complete reactor core loading. 


\section{B. SYSTEM AND COMPONENT DESCRIPTION}

The equipment provided for handling of fuel elements consists of the new-fuel shipping containers, new-fuel storage racks, preheat cells, fuel storage thimbles, fuel transfer cask (including supporting trolley and gantry crane), and fuel shipping cask.

\section{NEW-FUEL SHIPPING CONTAINERS}

Approximately 170 shipping containers are provided for shipment of new fuel elements in frozen sodium. These shipping containers consist of steel pipe permanently sealed at one end and a removable lid with a gas seal provided at the other end.

\section{NEW-FUEL STORAGE RACKS}

Seventeen racks, each designed to accommodate 10 fuel-element shipping containers, are provided along the walls of the reactor building.

\section{PREHEAT CELLS}

Three preheat cells are provided to facilitate removal of new fuel elements from shipping containers and prepare spent fuel for shipment. Each cell consists of a recess in the reactor floor with electrical heaters provided to melt the sodium inside the shipping containers. A mechanism is provided for remotely removing the shipping container lid and connecting the fuel-element cluster to the reactor shield plug.

\section{FUEL STORAGE THIMBLES}

Storage thimbles (260) are provided for irradiated fuel elements. Each thimble consists of steel tubing covered with a corrosion-resistant coating designed to prevent contamination of the fuel elements. The top of the tubing is encased in a concrete shield with provision for insertion of fuel element and storage shield plug. A nitrogen atmosphere is maintained inside the thimble. The bottom of the thimbles are immersed in a water pool. The water in the pool is circulated through a heat exchanger for removal of decay heat from the fuel.

\section{FUEL TRANSFER CASK}

The fuel transfer cask shown in Figure 30 is used for inserting and removing fuel from the reactor core and for transporting irradiated fuel elements inside the reactor building whenever shielding is required or it is desired to maintain a nitrogen atmosphere. The major components of the cask are a lead cylinder and adjustable lead skirt, a rotatable multichamber pickup assembly, a gas cooling system, and a gas interlock. A trolley mounted on a gantry crane supports and transports the cask.

Cask shielding is provided by a lead cylinder $20 \mathrm{ft}$ high, with 18-in. ID and 36-in. OD. The shield between the cask and the floor consists of a movable lead skirt which is lowered by three screw jacks.
The pickup assembly is used to remove each fuel element by sections. An electric motor with gear drive rotates the pickup assembly, and an index mechanism accurately aligns each chamber over the openings in the loading-face shield. Each chamber contains a grapple driven by a pneumatic cylinder. Five separate chambers accommodate the shield plug, hanger rod, irradiated fuel cluster, new fuel cluster, and seal plug. Latches support the lower sections when separating or connecting the fuel element. A periscope viewer allows the operator to inspect the disconnect mechanism at all times. A forced-circulation nitrogen cooling system provides cooling to the chamber containing the spent fuel element; a nitrogen atmosphere is maintained at all times in the chamber by the gas interlock.

All operations on the cask and its components are electrically or pneumatically controlled from the operator's platform. Mounted on the platform are lights, meters, and counters which indicate to the operator the status of the equipment.

Cask design is such that the internal pickup assembly may be removed remotely in the shielded service pit if necessary. Electrical and mechanical interlocks are provided to ensure a fail-safe unit.

\section{FUEL SHIPPING CASK}

A shipping cask is provided for shipment of irradiated fuel elements to a reprocessing facility. The shipping cask can accommodate eight fuel elements. Ten inches of lead shielding are provided to permit shipment of fuel elements after a 60- to 90-day decay period.

\section{FUEL HANDLING PROCEDURE}

New fuel is received in steel shipping containers and is packed in frozen sodium. Provisions are made for storage of new fuel in racks along the building wall. During refueling operations, the shipping container is loaded into a preheat cell by means of an overhead crane. The cell is purged with nitrogen, and the frozen sodium is melted using electric heaters. A mechanism within the cell removes the shippingcontainer lid and connects the fuel cluster to the seal plug at the top of the cell. The fuel transfer cask transfers the fuel cluster and seal plug from the preheat cell to the fuel storage area. Before the fuel cluster is inserted into the reactor core, the seal plug is exchanged for a reactor plug and intermediate hanger rod.

Irradiated fuel elements are transferred from the reactor to the fuel storage thimbles with the fuel transfer cask. After a 60- to 90-day decay period, the fuel elements are transferred to the fuel shipping cask which has been positioned in the preheat cells. The irradiated fuel elements are shipped eight at a time to the fuel reprocessing facility. 


\section{INSTRUMENTATION AND CONTROL}

\section{A. REACTOR INSTRUMENTATION}

Reactor instrumentation is provided for the measurement of neutron flux, temperatures, flow rates, sodium level, and control rod positions. The nuclear instrumentation block diagram is shown in Figure 31.

\section{FLUX INSTRUMENTATION}

The flux instrumentation is divided into seven channels: two source-range, two intermediate-range, and three power-range channels. These instruments provide adequate flux measurements over the power range from source level to $150 \%$ of design rated power. In addition to providing reactor control signals, the flux instrumentation is used to actuate the plant protective system. The seven neutron detectors are located in a circular pattern at the bottom of the loading-face shield. A neutron beam tube extends vertically from the top head of the calandria vessel to a position below each detector. All detectors are accessible through individual openings in the loadingface shield.

Two count-rate channels, which measure neutron fluxes between source level and $0.00025 \%$ of design rated power are used during reactor startup. Each channel consists of a $\mathrm{BF}_{3}$ chamber, which transmits flux information through a pulse amplifier to a countrate indicator and recorder, and to a period indicator and recorder. Two compensated ion chambers, which transmit to logarithmic amplifiers and to neutron flux recorders, are used for reactor startup over the range from $0.00001 \%$ to $10 \%$ of design rated power. Period signals are tied into the plant protective system so that if the period exceeds preset limits, an alarm sounds and a shutdown is actuated.

The three power-level channels, which employ uncompensated ionization chambers, cover the range of normal power operation. These channels transmit signals to the plant protective system (Figure 32). Coincident circuitry in the plant protective system is such that at least two of the three channels must register abnormally to initiate a setback or scram. If only one channel reads abnormally, an alarm is sounded. Signals from the power-level channels are directed through amplifiers and a selector switch to the neutron flux controller, which positions the control-safety rods in response to plant load demands.

Separate period recorders are provided for sourcerange channels, intermediate-range channels, and power-range channels, so that period recordings are available for all levels of operation.

\section{TEMPERATURE INSTRUMENTATION}

Fuel-channel-sodium exit temperatures are measured by thermocouples installed at the bottom of each orifice tube. Temperature signals from three selected fuel channels are used for normal reactor control as well as for activating the plant protective system through coincident circuitry. An alarm, setback, or scram may be initiated in the event of excessive fuel-channel-sodium exit temperatures. All other fuel channels are continuously monitored. A multichannel temperature recorder and a precision temperature indicator, common to all fuel-channel temperature elements, is provided. Additional thermocouples are located throughout the reactor vessel and in the biological shielding. Temperatures in these locations may be monitored by means of a single selector-indicator and a multichannel recorder for recording off-normal temperatures.

\section{SODIUM AND REACTOR AUXILIARY SYSTEMS}

Sodium systems are provided with instrumentation to measure sodium pressures, temperatures, leaks, flow rates, and levels. Instruments for making these measurements are identified on Figure 20. Pressuresensing elements utilize a $\mathrm{NaK}$-filled capsule welded in the line which communicates through a capillary tube to a transmitter. Sodium-temperature-sensing elements are removable. All sodium flow rates are measured by magnetic flowmeters or by differential-head meters. Alarm coils and incremental or continuousinduction-type transducers, or NaK-filled level-sensing elements are used for measuring sodium levels. Sodium level is measured over the total operating range, and high and low level alarms are provided.

Sodium-leak detectors are located on primary sodium equipment, which is inaccessible during operation. Each detector consists of a mesh-type electrode which becomes shorted when contacted by sodium.

\section{B. PLANT CONTROL SYSTEM}

The plant control system shown in Figure 33 provides for automatic operation over the range from $20 \%$ to $100 \%$ of design rated load, and for manual operation at any load.

The plant is designed to operate as a load-following system, with reactor power level and sodium flow rates varied according to steam demand. System frequency regulates the throttle valves and voltage controls excitation. Feedwater flow is controlled by a three-element controller. Steam flow and pressure vary excitation to the field windings of the EM pumps, thus controlling the flow of nonradioactive sodium to the steam generator. Total secondary flow information is transmitted to the linear induction pumps, and primary flow is adjusted to match secondary flow. The outlet sodium temperature from three representative fuel channels is used to control reactor power by initiating changes in control-rod position by cascading temperature control through the neutron flux controller. 
The following list indicates the major elements that are controlled as the plant load is changed during normal operation:

(1) Fuel-channel-sodium outlet temperature remains constant.

(2) Steam-generator outlet sodium temperature is held constant.

(3) Steam-throttle pressure is held constant.

(4) Primary and secondary sodium flow are varied according to load.

(5) Feedwater flow is varied according to load.

(6) Reactor power (neutron flux) is equated to load demand.

In the event of a sudden load decrease, e.g., throttle trip, the bypass control system directs $20 \%$ of the steam through a desuperheater to the condenser, and the remaining steam is released to the atmosphere. The relief valves and steam bypass system continue to operate until the load-following control instrumentation reduces sodium flows to maintain the $20 \%$ bypass-steam load conditions.

During shutdown periods, reactor decay-heat cooling is provided by dumping steam to the bypass system.

The plant control room is a separate room on the third floor overlooking the turbine-generator and reactor. A walkin-type console contains the reactor control instrumentation. The console includes a graphic panel with controls for the sodium heattransfer systems, the control instrumentation for the steam and condensate systems, and the power generation and distribution controls.

\section{TURBINE-GENERATOR PLANT}

\section{A. STEAM SYSTEM}

\section{GENERAL.}

The plant is designed on a unit basis with the reactor steam system supplying a single turbine set. Seven extraction points are used on the turbine to heat feedwater in six closed heaters and one directcontact heater. Deaeration of feedwater is accomplished in the condenser and the direct-contact heater. Makeup water as well as the distilled-water requirement for certain reactor plant processes is provided by an evaporator furnished with a preheater.

The plant is of the semi-outdoor design with the necessary weatherproofing and freeze protection provided where required for the equipment exposed to the weather. The reactor portion of the plant is completely enclosed with the turbine-generator set and certain auxiliary equipment outdoors.

An oil-fired, pressurized hot-water generator of the packaged type is used to supply hot water for preheating the sodium steam generator.

\section{STEAM GENERATING EQUIPMENT}

Three steam generating units each connecting to a main heat-transfer loop are designed to produce $1,835,000 \mathrm{lb} / \mathrm{hr}$ of steam at $2400 \mathrm{psig}$ and $1050^{\circ} \mathrm{F}$ at the turbine throttle. This rating is based on a final feedwater temperature of $540^{\circ} \mathrm{F}$ obtainable with seven feedwater heaters and a boiling pressure of 2500 psig in the evaporator section of the steam generator.

Furnished as a part of the steam generating equipment (and located adjacent to the turbine-generator set), three liquid-metal reheaters are in parallel on the sodium side to the steam generators. The function of the units is to resuperheat the steam exhausting from the high-pressure turbine to $1000^{\circ} \mathrm{F}$ at a pressure of 504 psig. The liquid metal leaving the reheater is returned to the steam generators at the junction of the evaporator superheater. The reheater operates uncontrolled without the use of additional pumping equipment to deliver sodium to the reheater. A nozzle placed in the sodium supply line to the steam generator provides the pressure drop to divert sodium to the reheater.

A three-function control system is provided for the once-through steam generator, which senses feedwater flow, steam flow, and sodium outlet temperature. Steam superheat controls are not provided since constant steam outlet temperature is provided regardless of plant loading within a tolerance of $\pm 5^{\circ} \mathrm{F}$. The steam pressure is maintained constant over the plant load range by use of a variable-speed boiler feed pump.

A pressure reducing and desuperheating station with a capacity of about $20,000 \mathrm{lb} / \mathrm{hr}$ receives steam at superheater outlet condition and delivers saturated steam at about 150 psig to various plant services. The cooling water required for this service is taken from the condenser condensate pump discharge.

Steam-generator construction is of the all-welded shell and tube (single-wall) type with steam and water in tubes and sodium in shell. A similar-type steam generator is being fabricated for installation in the Enrico Fermi Fast Breeder Plant.

\section{TURBINE-GENERATOR AND AUXILIARIES}

The turbine is a $250,000-\mathrm{kw}$ unit (nominal rating) of the tandem compound, reheat, condensing type which operates at $2400 \mathrm{psig}$ and $1050^{\circ} \mathrm{F}$ with reheat to $1000^{\circ} \mathrm{F}$. The maximum expected capability of the unit is $270,000 \mathrm{kw}$ based on $1.5 \mathrm{in}$. of $\mathrm{Hg}$ absolute average back pressure. 
Extraction steam for feedwater heating is taken from the various turbine stage bleeds for seven feedwater heaters.

The generator is hydrogen cooled. Hydrogen coolers installed integral with the generator casing utilize circulating water taken from the condenser inlet for rejecting generator heat losses.

A turbine lube-oil system consisting of:

(a) One lube-oil reservoir of about 3000-gal capacity

(b) Centrifugal oil purifier

(c) Electric-motor-driven lube-oil pumps, one ac and one $\mathrm{dc}$; the dc unit is used for backup

(d) One turbine-shaft-mounted, main lube-oil pump

Oil for the turbine-generator bearings and control system is provided by the ac-motor-driven pump when starting and stopping the set. Automatic transfer controls are provided to stop the motor-driven pump when the main unit is at normal operating speed, and all oil requirements are provided by the shaft-driven pump. Upon failure of the main pump and the ac-motor-driven pump, the dc-motor pump will supply the necessary oil. The latter pump is energized by the emergency power supply.

A turbine-generator startup panel is installed in the vicinity of the machine on which are located all necessary control equipment and instrumentation for startup of the set. After startup is completed, control and loading of the generator is accomplished from the central control room.

\section{CONDENSER AND AUXILIARIES}

One single-pass deaerating-type surface condenser with a divided water box is provided. The condenser is sized to maintain a backpressure at the turbine exhaust of 1.5 in. of mercury absolute with $85 \%$ clean tubes when provided with $55^{\circ} \mathrm{F}$ cooling water. The condenser is provided with a hotwell with sufficient storage of condensate for $5 \mathrm{~min}$ of operation at full load.

Three half-capacity hotwell condensate pumps are provided. Normal operation requires the service of two pumps with one in hot standby. The pumps are of the vertical, multistage centrifugal, submerged suction type; each is designed to deliver $720,000 \mathrm{lb} / \mathrm{hr}$ of $92^{\circ} \mathrm{F}$ steam condensate at a total head of $400 \mathrm{ft}$.

One twin-element, two-stage steam-jet air ejector provided with inter- and after-condenser is installed for condenser air evacuation. Cooling water for this unit is taken from the condensate pump discharge and forms a part of feedwater heating cycle. Minimum condensate flow through this unit is maintained by a control valve which will recirculate the condensate back to the condenser at low load. The unit is rated at a condenser backpressure of 1 in. $\mathrm{Hg}$ absolute.
Two motor-driven vacuum pumps are provided to evacuate the condenser steam space and circulating water lines during the startup of the plant.

Two circulating water pumps of the vertical mixed flow, removable internal element type, are installed to deliver cooling water to the main unit condenser. Each pump is half capacity and is driven by a 3 -phase, 2300-v weatherproof motor.

\section{FEEDWATER SYSTEM}

Condensate is heated to its final temperature of $540^{\circ} \mathrm{F}$ before entering the steam generators by passing the water from the hotwell successively through six closed feedwater heaters and a deaerator. The heaters, in order of increasing temperature, are as follows:

(a) Two low-pressure closed heaters

(b) One direct-contact deaerating-type heater

(c) Four high-pressure closed heaters

The four high-pressure heaters are equipped with a desuperheating and drain cooler section. The two low-pressure heaters are equipped with drain cooler sections.

The drains of each of the high-pressure heaters are cascaded to the next lower pressure heater. The last high-pressure heater delivers all the accumulated drains to the deaerating heater.

The drains of each of the low-pressure heaters are cascaded to the next lower pressure heater. The lowest pressure heater delivers its drains to the condenser.

Three half-capacity electric-motor-driven boiler feed pumps, each designed to deliver $1,000,000 \mathrm{lb} / \mathrm{hr}$ of water at a total head of $5900 \mathrm{ft}$, take their supply directly from the deaerating heater.

Feed-pump protection is provided by a minimumflow protection device which will recirculate feedwater to the deaerator to prevent pump overheating. In addition, a minimum-pressure switch is provided in the suction of each pump to shut down the pump in event of loss of feedwater flow.

A three-function feedwater control system, which senses feedwater flow, steam flow and sodium outlet temperature, is installed on each of the three steam generators. The feedwater flow is in turn controlled by means of regulating the boiler feed-pump speed.

The steam exıraction lines from the turbine to the high-pressure feedwater heaters are provided with reverse-current check valves to protect the turbine from backflow from the heaters. These reversecurrent valves will close should the level of drains within the heater become abnormally high. The valves are actuated by high-level switches installed on the heaters. 


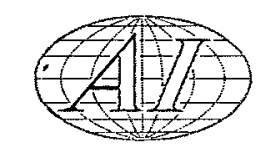

All other heater extraction lines have motoroperated valves installed which will be closed by high-level switches, preventing backflow to the turbine.

All extraction heaters are furnished with liquidlevel controllers, alarms, and drain control valves.

One horizontal evaporator with a deaerating preheater is provided to supply the makeup water required by the steam cycle. The complete unit is designed to produce $6500 \mathrm{lb} / \mathrm{hr}$ of steam vapor when utilizing extraction steam from the no. 4 heater. The vapor is delivered to the deaerator as well as the heating coil drains.

High-level overflow controls are provided on the deaerator to control operation of the evaporator. The evaporator is designed to utilize moisture separation equipment which will produce vapor with a total solids carryover not exceeding $250 \mathrm{ppb}$.

The evaporator is supplied with well water which is passed through a sodium zeolite treatment unit prior to entering the evaporator.

\section{WATER SUPPLY SYSTEM}

The entire water supply system consists of two deep wells delivering water to a 150,000-gal domestic water storage tank. Chlorinators are provided to treat the water prior to its delivery to storage. This water is utilized for general purposes within the plant as well as for steam-cycle makeup. Water for firefighting is provided from the condenser circulating system via an approved engine-driven fire pump.

Water for cycle makeup is supplied on demand by a transfer pump which delivers the water to sodium zeolite softeners and then to the evaporator. A treated-water storage tank is provided to store excess water generated by the evaporator and not used by the cycle. This water is used during plant startup as required for warmup or system filling. Water required for initial plant startup will be purchased and delivered by tank trucks to the site where it can be stored in the treated water tank and used to fill the system.

\section{PIPING}

Main steam piping to the turbine is $113 / 4$ in. OD by $2 \frac{1}{8}$ in. thick wall, leading in parallel lines from the steam generators to the turbine manifold, which is 20 -in. OD by $31 / 2$-in. thick wall. Reheat piping is 24 -in. OD by 2 -in. thick wall for the steam side. All main and reheat steam piping is fabricated of 5 $\mathrm{Cr}-1$ Mo alloy steel.

All main heat transfer sodium piping is fabricated of type 304 stainless steel.

\section{STEAM-GENERATOR WARMUP SYSTEM}

An oil-fired pressurized hot-water system is used to preheat the steam generators to $300^{\circ} \mathrm{F}$, prior to admitting sodium to these units at startup. The pressurized hot-water system bypasses the steam-generator feedwater system and consists of a circulating pump, the hot-water generator, and all piping and controls necessary to maintain steam-generator temperature until normal startup of the plant. The water supply for the warmup system is taken from deaerated storage.

\section{EMERGENCY COOLING}

Emergency and decay-heat cooling water is provided to the steam generators by a turbine-driven pump which takes suction from the deaerating heater. An emergency condensate pump transfers condensate from the condenser hot well directly to the deaerator, and an emergency circulating water pump circulates cooling water to the condenser. Most of the steam produced in the steam generator is returned to the condenser through the main steam bypass with the remainder supplied to the emergency pumps and to the deaerator.

The main steam bypass is sized to handle $20 \%$ of the rated flow and is equipped with an automatically operated desuperheater for reducing steam temperature prior to dumping to the condenser. In the event of a turbine trip, most of the steam is blown to the atmosphere until reactor power is reduced to approximately $20 \%$ of design rated power.

\section{B. ELECTRICAL}

\section{GENERATOR AND CONNECTIONS}

The main generator is a 3600-rpm, outdoor, hydrogen-cooled machine with a maximum rating of $320,000 \mathrm{kva}$ at 0.85 power factor and 45 -psig hydrogen pressure. Energy is generated at $24 \mathrm{kv}$ and stepped up to $138 \mathrm{kv}$ (Figure 34). Connection is made to the switchyard high-voltage bus and from there channeled to the connecting $138-\mathrm{kv}$ system. Connection from the generator terminals to the main transformer is made by a self-cooled isolated-phase bus. An isolated-phase, metal-clad cubicle containing the generator potential transformer required for metering, relaying, and surge protection equipment, is tapped off this bus. The generator neutral connection is grounded through a resistance-loaded distribution transformer.

\section{MAIN POWER TRANSFORMER}

The main power transformer is a two-winding, oilcooled, outdoor, three-phase unit, with a rating of $320,000 \mathrm{kva}$ and a full-load voltage ratio of 24 to $138 \mathrm{kv}$. The transformer is wye connected, grounded neutral on the high side, delta on the low side, and 
provided with two $2 \frac{1 / 2}{2} \%$ no-load taps above and below rated voltage. A set of three $109-\mathrm{kv}$ lightning arrestors are mounted on the transformer tank for surge-voltage protection. A thermal overload relay is provided for disconnecting the transformer if the safe-overload rating is exceeded. In addition an overtemperature indicator with alarm is included.

\section{HIGH-VOLTAGE SWITCHYARD}

The high-voltage switchyard contains two $138-\mathrm{kv}$ main buses supported by an overhead steel structure (Figure 35). A safety grounding mat composed of heavy bonded copper cables connected to driven ground rods are installed under the concrete support pad in accordance with standard practice. Suitably connected to the grounding system are exposed metal parts of switches, structures, transformers and circuit breaker tanks, fences, building steelwork, etc., as required by the substation safety codes. Four outdoor oil circuit breakers and associated disconnect switches are provided. Each circuit breaker is rated at $138 \mathrm{kv}$ and $5000 \mathrm{mva}$ interrapting capacity. A three-phase potential transformer for metering, synchronizing, and relaying is connected to each $138-\mathrm{kv}$ bus.

\section{PROTECTIVE RELAYING}

Conventional modern relaying is provided for the protection of the generator, main transformer, and $138-\mathrm{kv}$ busses. The relaying includes generator, transformer and bus differential schemes, generator overcurrent backup, loss of field, negative sequence, and ground fault relaying. Carrier-current relaying coordinated with remote terminal equipment protects the incoming transmission lines.

\section{STATION AUXILIARY POWER SYSTEM}

The station auxiliary power system reliably supplies the normal station auxiliary loads and provides a high degree of availability of power required during shutdown or post-incident periods (Figure 36).

Two main sources of auxiliary power are provided, one from an auxiliary transformer connected to the generator leads in a unit scheme and the other from an auxiliary transformer tied to the $138-\mathrm{kv}$ system. The latter, in addition to supplying its share of normal auxiliary power, supplies startup power. Each transformer is capable of supplying approximately twothirds of normal full-station-operation requirements. During startup with only one source available, the larger sodium heating load must be reduced before operating all the large auxiliaries at full capacity. Each auxiliary transformer supplies power to its own 4160-v bus through a normally open bus tie breaker connecting the two busses. With each source supplying approximately half of the normal requirements, both sources must be available for full-load operation. With but one source available, reduced load operation is possible until orderly shutdown can be accom- plished. Upon loss of one of the $4160-\mathrm{v}$ sources an automatic partial bus transfer closes the bus tie breaker after tripping from the dead bus all loads except the 480-v load center transformer.

The 4160-v system supplies the motors of the larger auxiliaries, frequency converters for the primary EM pumps, and two $480-v$ load centers. The two 480-v load centers supply directly the mediumsized auxiliaries and the smaller auxiliaries through several 480-v motor control centers located near the center of the load.

\section{AUXILIARY POWER TRANSFORMERS}

The two auxiliary power transformers are threephase, oil-immersed outdoor units with a 10-mva self-cooled rating and 12.5-mva forced-air-cooled rating. The transformer supplied from the generator bus is connected 24-kv delta on the high side and $4160-v$ grounded wye on the low side. The transformer supplied from the high-voltage bus is connected $138-\mathrm{kv}$ grounded wye on the high side, $4160-\mathrm{v}$ grounded wye on the low side, and has a deltaconnected tertiary winding. Transformers have four no-load voltage taps. Transformer differential relaying is provided.

\section{4160-VOLT SWITCHGEAR}

The 4160-v switchgear is located in the switchgear area and is divided into two busses, each connected to one of two auxiliary transformers. The busses are not normally parallel except briefly while making a manual bus transfer as during startup. The switchgear is of the conventional metal-clad-type with drawout air circuit breakers and contains all necessary relays and instrument transformers. The breakers are rated $250 \mathrm{mva}$ interrupting ability, $2000 \mathrm{amp}$ continuous.

\section{480-VOLT LOAD CENTERS}

Two 480-v load centers, one located in the switchgear area and the other located in the reactor area, supply the 480-v station auxiliary power requirements. Each load center is of the double-ended type with a 750-kva transformer feeding each end. One load center supplies primarily reactor and turbine generator auxiliaries, and the other supplies power for preheating the sodium tanks and liner. Electricinduction and resistance heaters heat the sodium pipes and tanks to $350^{\circ} \mathrm{F}$ for filling operations and maintain this temperature during shutdown by on-off cycling. Heating controls are contained in control center units.

Load centers are the indoor-unit substation type in the reactor area and outdoor type in the switchgear area with transformers close-coupled to the switchgear. Metal-clad switchgear containing drawout lowvoltage air circuit breakers is used. 



\section{SITE AND BUILDING}

\section{A. PLANT SITE}

The assumed site is a level area adjacent to a river in a temperate zone with highway, railroad, and river barge services available (Figure 38 ). The reactor, reactor service systems, fuel handling system, control and office areas are enclosed by a single structure and the turbine-generator is located out of doors. The reactor and radioactive portions of the systems are contained in shielded cells. The reactor bay of the building is serviced by a 30 -ton crane, in addition to the gantry crane used for fuel handling and reactor equipment installation and maintenance. A 75-ton bridge crane services the reactor auxiliary bay. The high-voltage switchyard, cooling-water intake and discharge structures, and liquid-waste treatment system are remote from the building.

\section{PLANT OUTLINE SPECIFICATIONS}

(a) The assumed site is $900 \mathrm{ft}$ wide by $1200 \mathrm{ft}$ long, on hard ground, with the long axis running in an east-west direction

(b) Soil conditions at the site are normal

(c) Structural live loads for floors are determined by the Uniform Building Code, Chapter 23, except as noted

(d) Wind load is as specified in the Uniform Building Code

(e) Earthquake loadings are as specified in the Uniform Building Code, Zone 3

\section{SITE AND SITE SERVICES}

The main plant is located $250 \mathrm{ft}$ north of the southern boundary and $490 \mathrm{ft}$ east of the western boundary of the site (Figure 38 ). The condenser cooling water is taken from the river to the north of the main plant. The water treatment area is located to the north of the turbine-generator area, and the electrical switchyard is located to the west of the turbine-generator area. The railroad enters the site from the east and services the reactor bay and the auxiliary bay. Vehicle access is via paved roadway from the south. A plant road system is provided around the main plant with parking at strategic locations. The entire property is fenced with three strands of barbed wire on steel stakes. The main plant is enclosed with chainlink fencing, entrance to which is controlled by a guard station at the main gate. A similar chainlink fencing also encloses the switchyard area.

\section{GRADING AND DRAINAGE}

Grading of the site includes only that necessary for construction of roads, structures, and work areas. Surface drainage is used where practicable except for the immediate area of the main plant, where catch basins and buried pipe are provided. Roof drainage is discharged into the underground pipe system. Culverts are provided where surface drainage crosses roads and railroad tracks.

\section{UTILITIES}

Water supply is from a local water main capable of delivering $3000 \mathrm{gpm}$. A water treatment plant capable of providing $90 \mathrm{gpm}$ or $130,000 \mathrm{gal} / \mathrm{day}$ of softened potable water for plant makeup and domestic supply is provided.

Fire protection is provided by means of an 8-in.diam pipe loop, complete with hydrants, isolating valves, and connections to lines for hose reels within the building. This loop encircles the main plant area with hydrants spaced at $200-\mathrm{ft}$ intervals. Two hose carts with accessories are provided. Normal fire-line pressure is maintained by means of an automaticstartup, 75-hp, motor-driven fire pump, rated at $1000 \mathrm{gpm}$.

General area, yard, and plant-fence lighting is provided by means of incandescent floodlights mounted on the buildings or steel poles strategically located throughout the plant. Illumination level is not less than $0.2 \mathrm{ft}-\mathrm{c}$ along the plant fencing. Temporary power at $380 \mathrm{~V}$ is provided at the site during the construction phase.

Sanitary wastes are disposed of by the use of a single-unit sewage plant based on the principle of aerobic decomposition. Radioactive liquid waste is contained in holdup tanks until decay permits controlled release to the cooling-water discharge.

\section{B. BUILDING AND BUILDING SERVICES (Figures 39 through 49) \\ 1. REACTOR AREA}

A high-bay portion of the building, which is $180 \mathrm{ft}$ long by $66 \mathrm{ft}$ wide and $74 \mathrm{ft}$ high, houses the reactor and fuel handling system. A 30-ton-capacity bridge crane covers the entire area. This crane handles equipment during construction and during operation and is used for maintenance handling of the spent fuel shipping casks. A fuel handling cask mounted on a gantry transfers fuel to and from the reactor. To permit delivery of heavy components, a railroad spur track extends into the main building under the crane. Concrete or masonry walls completely separate this area from the rest of the plant; openings and means of access are reduced to a minimum.

\section{a. Construction}

Shielded vaults are located above and below ground level with the reactor vault below grade. The reactor vault is surrounded by $3 \mathrm{ft}$ of concrete, and the 
shiclded vaults are surrounded by $7 \mathrm{ft}$ of concrete with sealed access hatches in the roof of vaults for equipment removal and installation. The building structure above the floor and vault roof is a steel frame structure with insulated metal siding (3 in. thick) to roof.

\section{REACTOR AUXILIARY BAY AREA}

Another high-bay section, which is $90 \mathrm{ft}$ wide, $205 \mathrm{ft}$ long, and $79 \mathrm{ft}$ high, houses the reactor auxiliary bay area.

\section{ADMINISTRATION AND SERVICE AREA}

Electrical gear for the building is located in the basement. The offices, electrical and maintenance shop, hot and cold change rooms, toilets, health physics, first aid, reception, lunch, and conference rooms are located on the first floor.

Located on the second floor are the cable spreading room and heating and ventilating equipment rooms. Third floor facilities include the control room, toilet, instrument repair, and heating and ventilating equipment room.

\section{a. Construction}

Conventional concrete flooring with metal-stud metal-lath and plaster partitions are provided.

The one-story portion consists of porcelain enamel curtain walls and porcelain enamel panels for exterior walls. The three-story portion has insulated metal siding on exterior walls. Both sections are of steelframe construction.

\section{DECONTAMINATION AREA}

This area includes the equipment decontamination room and a small hot change room with toilet. Conventional concrete floors, concrete walls, and roof with plaster walls and partitions are provided. Partitions are of masonry plastered both sides.

\section{FIRE PROTECTION SYSTEM}

The systems and equipment conform to the applicable portions of the AEC Manual, Volume 6000; the requirements of the National Board of Fire Underwriters (specifically NBFU Pamphlets No. 10, $12,13,14,30,69,71$, and/or 72).

Fire-protection systems and equipment consist principally of automatic sprinklers, automatic carbon dioxide extinguishing systems, automatic and manual fire-alarm systems, and hand extinguishers (Figures 50 through 52).

\section{HEATING, VENTILATING, AND AIR CONDITIONING (Figures 53 through 56)}

The reactor building ventilation system is designed to the following conditions:
(1) To provide general heating and ventilating requirements for personnel comfort

(2) To control the direction of all air movement within the building so that any airborne contaminants will pass from areas of lesser to areas of greater contamination potential

(3) To exhaust only filtered air to the atmosphere from areas where any contamination potential exists

Administration and general service areas are separately ventilated by a dual duct system supplying tempered air to individual room mixing-box units. All administrative offices, clerical, lobby, receptionroom, first-aid-room, and lunch-room areas are supplied with $5900 \mathrm{cfm}$ of filtered, tempered air. All air supplied to the lunch room, first-aid room, and health-physics room $(1100 \mathrm{cfm})$ is exhausted to the filter room through an exhaust fan. The remainder of the air is exhausted to the corridors which serve as a plenum for recirculated air and makeup for toilet and storage areas. When heating is not required, the exhaust fans return air to atmosphere and 100\% outside air is supplied to obtain maximum cooling effect. The amount of recirculated air is controlled by modulating dampers positioned by a thermostat in the outdoor air stream.

Temperatures in the rooms supplied directly from the main air-supply unit are individually controlled by a room thermostat which positions dampers in the dual takeoffs from the central supply system. Hot plenum temperature is controlled by a plenum thermostat which is adjusted for outdoor temperature changes.

The administration area is maintained at approximately atmospheric pressure by means of manual balancing dampers in the supply and return duct systems.

Electrical switchgear, battery room, and dieselgenerator room are heated and ventilated through a separate system supplying $16,000 \mathrm{cfm}$ of outside air to this area. The diesel-generator room receives 1800 $\mathrm{cfm}$ and the battery room $2200 \mathrm{cfm}$. All air to these areas $(4000 \mathrm{cfm})$ is exhausted to atmosphere. Static pressure in these areas is maintained at approximately atmospheric pressure by means of manual balancing dampers.

A duct thermostat controls the heating coil output to maintain $65^{\circ} \mathrm{F}$ minimum inside temperature during winter operation.

The control room, cable spreading room, instrument repair room, and observation room are provided with a separate air-conditioning system to maintain uniform temperature and humidity. Air conditioners supply $9600 \mathrm{cfm}$ of air to this area. Static pressure is set at $1 / 16$ in. of water above normal atmospheric pressure by means of manual air-volume 
dampers in the duct work. Cooling coils are controlled by return air temperature and a room thermostat. Individual controls in each room control the output of reheat coils to maintain constant space temperatures.

The reactor high-bay area is separately ventilated through a filtered, tempered air-supply system providing approximately 2 volume air changes of outside air per hour. A 35,000-cfm volume of air is supplied to the area and is exhausted to the effluent stack through a filtered exhaust system. Static pressure regulators and air volume controls maintain the area at a constant static pressure of $1 / 8$-in. water gage below atmospheric pressure to ensure that any building leakage will be inward and thus carried to the filtered exhaust system. A room thermostat controls the output of a steam heating coil to maintain a minimum winter space temperature of approximately $65^{\circ} \mathrm{F}$.

A separate ventilating system supplies $5700 \mathrm{cfm}$ of filtered, tempered air to the equipment decontamination room, toilet and shower, and the service area above cold-trap vaults and primary pumps. All air from these areas is exhausted to the stack through the central-filtered exhaust system.

A room thermostat in the decontamination room and in service area controls a steam heating coil which maintains a minimum winter temperature in these areas of $65^{\circ} \mathrm{F}$.

A system of static pressure regulators and air volume controls maintain static pressures in the areas listed below:

(1) Maintenance room, $1 / 16$-in. water gage below atmospheric pressure

(2) Hot change room, emergency equipment room and hall $1 / 16$-in. water gage below atmospheric pressure

(3) Laundry, $1 / 32^{-i n}$. water gage below atmospheric pressure

(4) Cold change room and clean issue room, approximately atmospheric pressure

A steam coil in the supply unit is controlled by a room thermostat and/or a discharge-duct thermostat to maintain a minimum winter temperature in the maintenance area of $70^{\circ} \mathrm{F}$. Wall-type steam convector units in the cold change room, hot change room, and laundry will be controlled by room thermostats to maintain these areas at comfortable winter temperatures, approximately $75^{\circ} \mathrm{F}$ in the change rooms and $70^{\circ} \mathrm{F}$ in the laundry.

The reactor auxiliary bay area is provided with thermostatically controlled steam unit heaters for winter heating. Summer ventilation is provided by roof exhaust fans and sidewall adjustable louvers. The louvers are motor operated and interlock to close when exhaust fans are shut down.

All air exhausted from areas of potential contamination passes through the central filter and exhaust system before being discharged to the atmosphere through the stack.

The filter system includes a bank of $85 \%$ efficient prefilters and a bank of $99.97 \%$ absolute or final filters. A $100 \%$ standby capacity is provided, and the filter banks are valved so that each bank can be isolated for changing filters without system shutdown.

In case of fire in any area of potential contamination, the fans supplying ventilation air to the areas are shut down and supply ducts to the areas are shut off by means of valves. Central exhaust fans remain in operation to maintain the areas at the set negative static pressures. Exhaust air flow is then reduced to leakage flow, and this air is directed by means of bypass valves through an orifice-type wet dust collector which acts to clean the air of the heavy particulate resulting from the fire and thus reduce the dust loading on the final filtering system.

In addition to the filters and dust collector, the exhaust system includes a 100-hp exhaust fan with motor connected to the regular power supply and a 100-hp standby exhaust fan with motor connected to the emergency diesel-generator power.

Ventilation to the filter room is supplied by an exhaust air fan. A system of static pressure regulators and air volume controls maintains the filter room at $1 / 8$-in. water gage below atmospheric pressure.

Each exhaust fan is provided with variable inlet vanes positioned by a static pressure regulator to maintain a constant air flow through the exhaust system under normal operation. The effluent release stack is 48 -in. in diam and $125 \mathrm{ft}$ high.

\section{SAFETY CHARACTERISTICS}

\section{A. INTRODUCTION}

The only operating sodium graphite reactor, the Sodium Reactor Experiment (SRE), has been demonstrated to be extremely stable. Operating experience has shown that very little control-rod movement is required to maintain reactor power. In a test covering $144 \mathrm{hr}$ the total operating time of the control rod was measured to be $3.5 \mathrm{~min}$. This unusual stability is due to the small overall temperature coefficient of reactivity, the important part of which is that contributed by the fast-acting Doppler coefficient of the fuel.

The other major contributions to the temperature and power coefficients are those associated with the 
graphite and sodium coolant, both of which are positive and produce an overall isothermal temperature coefficient for the SRE which is slightly positive up to about $1200^{\circ} \mathrm{C}$, at which point it becomes negative. The graphite contribution is important only in very slow transients since the time constant associated with the graphite is approximately $10 \mathrm{~min}$. The fuel and coolant contributions are very closely coupled and, together, yield a negative coefficient with a time constant of about 9 sec. This information on SRE stability was established by a series of pile oscillator experiments. ${ }^{12}$ These experiments covered a range of reactor periods from $50 \mathrm{msec}$ to $2000 \mathrm{sec}$, and have firmly established the stability of the SRE. While no kinetic studies of the 256-Mwe SGR have yet been made, it is expected that its stability will be at least as good or better than that of SRE; this because the reactor is expected to have an overall temperature coefficient which is slightly negative at operating temperatures and because the graphite temperature is even more loosely coupled to those of the fuel and coolant; the graphite coefficient in the large plant will therefore have an even longer time constant than it does in the SRE.

There is an additional feature of the 256-Mwe SGR which should make it even safer than SRE. The primary coolant piping and associated galleries have been eliminated, and all radioactive materials are contained in the reactor vessel. This design eliminates the potential hazard associated with possible failure of components in the primary cooling system.

As with all sodium graphite reactors, the 256-Mwe plant operates at low pressure; high pressures are found only in the steam portion of the plant, which is separated from the reactor and primary coolant system by the nonradioactive secondary coolant loop.

All radioactive components, including the reactor and associated equipment, are located in shielded areas. Shielding reduces radiation levels in all working areas to well below normal standards. Secondary nonradioactive-sodium coolant circuits transfer heat from the radioactive primary sodium coolant to the steam portion of the plant. The steam generators are located in the working area above the reactor floor level.

Containment of radioactive fluids is provided by welded steel containers and piping, steel liners on the concrete shielding, and sealed joints. An inert-gas atmosphere is used in all areas containing primarysystem piping and components. This prevents any possible reaction between radioactive sodium and air.

Within the reactor there is no releasable potential energy from pressurization or chemical reaction because the reactor operates under low pressure and because all materials used in the reactor are chemically compatible. There is no necessity for a gastight pressure shell surrounding the reactor. A typical industrial building structure is used.

\section{REACTOR THERMAL SAFETY}

There are three independent sodium heat-transfer circuits for cooling the reactor. During a plant shutdown one or more of these circuits may be used for forced cooling of the reactor to remove stored and decay heat. An emergency power system, using storage batteries, a diesel-driven generator, and a turbine-driven generator, ensures that shutdown coolant flow is maintained during any electrical power failure.

If loss of all forced sodium flow should be postulated, natural convection flow within the reactor and in the three sodium coolant loops would provide continuous cooling of the reactor after shutdown. Even without flow in the coolant loops, a slow rise in overall reactor temperature after shutdown is ensured by the large heat capacity of the reactor structure. The upper limit of the reactor temperature $\left(1600^{\circ} \mathrm{F}\right)$ would be established in approximately 8 to $10 \mathrm{hr}$, which is ample time to establish emergency cooling.

\section{REACTOR NUCLEAR SAFETY}

An automatic plant control system provides for safe operation of the reactor power plant under normal conditions. A plant protective system provides additional automatic control of the reactor systems for safety against failure or improper operation of any component. The protective system is designed for reliability, with reactor scrams reduced to a minimum and in general replaced by a power reduction.

Combination control and safety rods, which regulate power level during normal operation, have a motion which is limited in speed to ensure that excessive reactivity cannot be inserted by erroneous action. Negative reactivity can be quickly inserted by de-energizing the motor, which allows the poison rod to fall by gravity into the reactor core.

The strong, negative, prompt fuel temperature coefficient of reactivity provides reactivity control over upsurges in fuel temperature. The slightly negative overall steady-state reactor power coefficient at operating temperature further ensures that any increase in power is counteracted by a decrease in reactivity.

\section{B. STRUCTURAL SAFETY OF REACTOR AREA}

\section{REACTOR STRUCTURE AND CONTAINMENT FEATURES}

Primary containment structure for the sodium and inert-gas atmosphere includes the core tank, coretank bellows, loading-face shield, and cavity liner.

The containment vessel serves as secondary containment for any sodium that may leak from the core tank. If leaks should occur in the core tank, the 
sodium is retained by the containment vessel at the level necessary to assure natural circulation to remove decay heat.

The concrete biological shielding adjacent to the reactor, including the loading-face shield, heatexchanger removal plugs, and pump removal plugs, is continuously cooled by the water cooling system to prevent excessive thermal gradients and high temperature.

\section{SUBSTRUCTURE}

Concrete cells which contain the radioactive primary-service-system equipment are lined with sheet steel on the sides and bottom to serve as secondary containment in the event of sodium leakage into the cells.

An inert-gas atmosphere is continuously maintained in the cells. The use of inert gas reduces the oxygen content in the cell asmosphere to a negligible amount and eliminates chemical reactions in the event of a sodium liquid or vapor leak into the cells. The inert-gas pressure is held slightly above atmospheric. This positive pressure minimizes oxygen in-leakage, while the low pressure differential minimizes inert-gas losses.

Access to the cells is through stepped concrete hatches. These hatches are sealed to minimize vapor or gas leakage into or out of the cells. The external surfaces of the cells exposed to subsurface water are completely covered with a waterproof membrane. The steel cell liners serve as an additional barrier to prevent leakage.

\section{REACTOR PLANT PROTECTIVE SYSTEM}

Instrumentation and control is provided for the purpose of detecting rapidly any off-normal condition in the reactor plant, and when necessary, automatically reducing reactor power level and coolant flow. This instrumentation and control system constitutes the reactor plant protective system (Figure 32 ). It is in addition to the plant control system, which serves to regulate power generation during normal operation.

Off-normal conditions could originate from any of several causes, including the following:

(1) Failure of the plant control system

(2) Improper operation of a component while on manual control

(3) Failure of a system component

In the event of an off-normal condition which is of such severity that its continuation could cause damage to any part of the reactor plant, the protective system would take corrective action automatically. Corrective action would be in the form of reducing reactor power or scramming the reactor.

\section{DESIGN EMPHASIS}

Safety and reliability are the two prime considerations in the design of the protective system. Because excessively complex safety systems can reduce the reliability of the plant, a balance is sought which ensures adequate safety while minimizing power outages caused by false (spurious) signals.

\section{a. Safety}

Many safety features are incorporated into the reactor design, as discussed in IX-D. These safety features minimize the severity of any possible accident, ensuring reasonable safety for personnel even without the existence of the plant protective system. The protective system is an additional safety feature to protect the plant investment as well as to arrest any condition which could potentially create hazard to personnel.

Some of the important safety features incorporated into the protective system are the following:

(1) Fail-safe circuits and equipment wherever possible

(2) Duplication of circuitry, so that failure of any one circuit leaves one or more other circuits intact and operable

(3) Backup circuits using entirely different types of sensing elements

\section{b. Reliability}

Reliability of the protective system is maintained in several ways. Highly reliable individual components are used, having coincident circuitry for the source of shutdown signals. Testing and monitoring systems determine proper operation of the protective system circuitry. Several different types of protective-system action are employed. In these ways plant outages are reduced to a minimum, while adequate safety is maintained to protect personnal and prevent damage to the reactor plant caused by offnormal conditions.

\section{c. Coincident Circuitry}

Coincident circuitry is used for the source of all setback and scram signals except the manual and period signals. Generally, three sensing instruments are used for receiving signals relative to any given variable which should require corrective action if abnormal. With this type of coincident circuitry, corrective action is not taken unless at least two of the three sensing instruments give abnormal signals simultaneously.

Though each circuit is fail-safe, the signal given by the failure of a single circuit in a coincident circuit arrangement merely causes an alarm. The malfunction detection circuit then actuates the appropriate 
annunciator. This permits remedial action without loss of plant output when a single circuit failure occurs. A failure or abnormal signal on either of the remaining two circuits would then cause reactor setback or scram.

Manual signals to initiate any power change require no other signal. This permits the operator to reduce power manually. Period signals from the sourcerange channels and intermediate-range channels produce shutdown functions when operating within their respective ranges when preset limits are reached. These shutdown functions are automatically cut out when the power-range channels are in operation, and the period signals from the power range channels produce setback functions when a preset limit is reached.

\section{d. Testing and Monitoring System}

The testing and monitoring system is used to make regular checks on the complete functioning of the circuitry in the protective system. Indicators and error-detecting circuits detect any failures or unsafe conditions. These circuits also detect any drifting or aging of components so that repair or replacement can be made before failure occurs.

\section{e. Protective System Action}

Types of protective system action taken in the event of off-normal conditions include:

(1) Alarm

(2) Rod interlock

(3) Setback

(4) Scram (shutdown)

By the combination of these various types of protective action, reliability is ensured while maintaining the maximum practicable level of safety.

\section{f. Protective System}

A block diagram of the reactor-plant protective system is shown in Figure 32. This system consists of the circuits which cause the various types of corrective actions necessitated by off-normal and emergency condition, plus circuits for functional testing, monitoring, and malfunction detection.

\section{(1) Alarm}

Alarm annunciators which do not initiate automatic corrective action are provided to warn the operator whenever an important reactor variable reaches an off-normal condition. They include warnings from reactor auxiliary systems as well as from the principal reactor systems.

An alarm makes the operator aware of off-normal conditions in any circuit, whether caused by an operating signal through a functioning circuit or a signal caused by failure of a circuit. Each alarm consists of an audible annunciator and a visual indicator, the latter indicating which particular variable is not within its operating range. The operator must acknowledge each alarm signal by pushing an appropriate button. This silences the audible signal, but leaves a visual indication of the off-normal condition until it has been corrected.

All signals which may cause automatic corrective action have alarms associated with them. These include all signals associated with rod interlock, setback, or scram action. In most cases a no-action alarm set point is established, so that this alarm occurs before the automatic set point is reached. The no-action alarm warning generally allows the operator time to make any necessary manual correction, so that automatic action is not required.

Automatic action is provided for those situations in which the operator does not have time to act or fails to act properly in response to the no-action alarms. Automatic action is accompanied by alarms which indicate the type of action and the off-normal variables. The alarm system is further arranged to give the operator a signal as to which off-normal condition first occurred to cause an automatic power reduction, even though several variables may be shown to be out of the normal operating range following the automatic action. When automatic power reduction is initiated, there is an additional audible annunciator which sounds appreciably louder than the other protective system alarm annunciators.

\section{(2) Rod Interlock}

The rod-withdrawal interlock circuit prevents withdrawal of the control rods when conditions exist which would result in an incorrect flux level indication or potentially unsafe reactor startup conditions caused by one of the following:

(a) Low-detector supply voltage

(b) Nuclear instrument power failure

\section{(3) Setback}

Any off-normal condition arising within the reactor as a result of changes in reactor power level, coolant temperature, or coolant flow must be corrected before reactor temperatures or rates of change of temperatures become excessively high. The setback in reactor power level is the first automatic action to correct such conditions within the reactor and is intended to correct any off-normal conditions in the reactor itself without a complete shutdown and without introducing further rapid temperature transients associated with scrams.

A setback causes the regulating rods to be inserted at a controlled rate resulting in a relatively slow power reduction. The variables and necessary conditions for initiating a setback are listed in Table IV. 
TABLE IV

\section{SETBACK}

\begin{tabular}{c|l}
\hline \multicolumn{1}{c|}{ Variable } & \multicolumn{1}{c}{$\begin{array}{c}\text { Condition of } \\
\text { Variable to } \\
\text { Initiate Setback }\end{array}$} \\
\hline $\begin{array}{l}\text { Neutron flux (coincidence) } \\
\begin{array}{c}\text { Sodium temperature at fuel- } \\
\text { channel outlet }\end{array}\end{array}$ & High \\
$\begin{array}{c}\text { Period (power range) for initiating } \\
\text { setback during normal opera- } \\
\text { tion 1\% to 150\% }\end{array}$ & Short \\
$\begin{array}{l}\text { Manual setback } \\
\text { Primary and secondary sodium } \\
\text { flow }\end{array}$ & Button depressed \\
\hline
\end{tabular}

Setbacks are initiated whenever a condition is not corrected after indication by an alarm and increases in severity to the setpoint for a setback. Setback action automatically lowers the control rods at a regulated speed, thereby reducing reactor power. Power reduction is continued until all conditions requiring a setback are corrected.

\section{(4) Sodium Temperature at Fuel-Channel Outlet}

Setback initiated by high sodium outlet temperatures serves to prevent thermal damage. The temperatures are obtained from thermocouples measuring exit sodium temperatures from selected fuel channels.

\section{(5) Period}

A setback may be initiated by period signals from channels V, VI, or VII in the event of an excessively rapid rate of rise of the thermal neutron flux during reactor power operation. High-power-level scram circuits provide additional security against damage from a rapid rate of power rise. An unnecessary potential source of power reductions from false instrumentation signals is eliminated by using a 200 mesec electronic delay timer in the period circuitry during normal operation after startup.

\section{(6) Scram}

An automatic reactor scram is a rapid shutdown action, resulting in insertion of all control-safety rods into the reactor core. It is only initiated if all other automatic measures of the plant protective system should fail to correct a condition which is potentially dangerous to the plant and personnel. The reactor may be scrammed manually if the operator is not satisfied that a serious condition is being adequately corrected.

Variables and conditions necessary for initiating a reactor scram are listed in Table $V$. The power, flow, and temperature circuits have scram set points beyond the alarm and other protective-system set points, to permit operator or automatic action before a scram. In the case of a severe earthquake or loss of electric power to all three of the primary sodium pumps, the reactor is scrammed immediately without a prior alarm or lesser action.

TABLE V

REACTOR SCRAM

\begin{tabular}{l|l}
\hline \multicolumn{1}{c|}{ Variable } & \multicolumn{1}{|c}{$\begin{array}{c}\text { Condition of } \\
\text { Variable to } \\
\text { Initiate Scram }\end{array}$} \\
\hline $\begin{array}{l}\text { Reactor power level } \\
\text { Sodium flow rate } \\
\text { Intermediate range }\end{array}$ & $\begin{array}{l}\text { High } \\
\text { Low } \\
\text { Shource range }\end{array}$ \\
$\begin{array}{l}\text { Sodium temperature at fuel- } \\
\text { channel outlet }\end{array}$ & $\begin{array}{l}\text { Short period } \\
\text { High } \\
\text { Electric power to sodium pumps }\end{array}$ \\
Earthquake & $\begin{array}{l}\text { all pumps } \\
\text { Severe accelera- } \\
\text { tion of structure }\end{array}$ \\
Reactor sodium level & Low \\
Manual scram & Button depressed \\
\hline
\end{tabular}

This protective system is designed to permit all action alternatives which could prevent a scram, when such alternatives are available without endangering the reactor and personnel. A scram causes greater power loss, time delay, and thermal shock, than other operator or protective-system action.

\section{SAFETY FEATURES}

Many safety features are incorporated into the reactor design. These features decrease the probability of an accident, reduce its severity, and shut the reactor down in case of any accident in which conditions are not brought back to normal by the plant-control or protective-system instrumentation or operator action.

\section{CONTROL-SAFETY ROD}

A control-safety rod description is given in section II.

\section{PLANT CONTROL SYSTEM}

The plant control system, described in section VI, is designed to match power generation to power demand, and simultaneously to maintain safe conditions during normal operation. For example, a limited rate of change of sodium flowrate is provided in the sodium-flow control system. This prevents fast temperature transients which could cause excessive thermal stresses or overheating. Relatively rapid transients can occur, however, by a failure of a sodium coolant pump, as discussed in IX-E-3. 


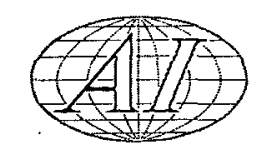

\section{ALTERNATE ELECTRIC POWER SOURCES}

Electric power for normal plant operation is available from both the external power supply and the generators in the reactor plant. An alternate power supply is thus provided whenever either an internal or external power outage occurs. In the event that both these normal sources of power should fail simultaneously, electricity would be supplied by the emergency power system for emergency needs only.

The emergency power system consists of storage batteries, a diesel-driven generator and a turbinedriven generator. The storage batteries supply power for critical loads during the time necessary to bring the generators to their full power. In this way continuous power is ensured for safety during shutdown.

\section{HEAT-REMOVAL CHARACTERISTICS}

\section{a. Independent Heat-Transfer Circuits}

The use of three independent heat-transfer circuits for removing heat generated in the reactor ensures that failure of any circuit will not leave the reactor without external cooling. Though the reactor may sometimes be operated using only two of the three heat-transfer circuits, it would never-be operated with only one such circuit. However, a single circuit may be used to remove decay heat from the reactor after shutdown.

\section{b. Upper Plenum Sodium}

The upper reactor plenum contains a large quantity of liquid sodium which mixes with the sodium flowing past the fuel channels before discharge into the three heat-transfer circuits. In the event of overheating of the sodium in any of the fuel channels, the upper plenum mixing would ensure that the localized or transient high temperatures would be reduced. If any sodium vapor should be formed in a fuel channel (which could possibly happen with the formation of a severe restriction), the vapor would be condensed in the upper plenum, and there would be no significant pressure rise. During full-power operation the upperplenum, sodium temperature is $\sim 400^{\circ} \mathrm{F}$ below the sodium boiling point

\section{c. Sodium Convection Flow}

Natural convection flow in the sodium coolant loops is sufficient to remove afterglow heat from the reactor after shutdown in the event of the simultaneous loss of power to all coolant pumps. Total loss of all pumps is highly unlikely, however, since there are three separate sodium coolant loops and emergency power sources.

\section{d. Core-Structure Heat Capacity}

If the sodium coolant loops should fail in their heat removal function after a shutdown, the large heat capacity of the core structure and coolant would ensure a slow reactor temperature rise. In such an event, sodium convection flow would provide distri- bution of fuel afterglow heat within the reactor, transferring the heat to the graphite, to the reactor structure, and the biological-shield coolant. These heat capacities are sufficient to ensure that boiling of the sodium would not be reached for a period of 8 to $10 \mathrm{hr}$, which is ample time to establish emergency cooling.

\section{REACTIVITY COEFFICIENTS}

\section{a. Prompt-Fuel Temperature Coefficient of Reactivity}

The prompt-fuel temperature coefficient of reactivity results from changes in the resonance absorption cross section of the fuel, particularly the $\mathbf{U}^{238}$ isotope, caused by the Doppler effect of broadening resonances. In the sodium graphite reactor, which has a large proportion of $\mathrm{U}^{238}$ in the fuel, resonance absorption provides an immediate significant reduction in reactivity whenever fuel temperature is raised.

The magnitude of the prompt-fuel temperature coefficient of reactivity for the SRE has been calculated to be $-1.68 \times 10^{-\overline{5}} /{ }^{\circ} \mathrm{F}$. The exact magnitude of the prompt-fuel temperature coefficient is a function of reactor dimensions, but it is strongly negative for any similar sodium graphite reactor whether using UC or metal fuel.

Because most of the heat is generated within the fuel element, its response to a change in reactor power is rapid and quickly tends to reduce the power level in any type of increased reactivity transient. Thus, it acts as a strong retardant to large power excursions.

\section{b. Power Coefficient of Reactivity}

The overall, steady-state reactor power coefficient of reactivity is slightly negative, so that following any increment of power increase, the reactor tends to reduce power because of reduced reactivity. This power coefficient of reactivity is primarily determined by the individual components of the temperature coefficient of reactivity and by the relative changes in temperature of these components as the reactor power is changed. In addition to the prompt-fuel temperature coefficient, there is a delayed component of temperature coefficient associated with changes in graphite temperature. A change in graphite temperature affects both the neutron temperature (hence the microscopic cross sections) and the material density (macroscopic cross sections). The contribution to the overall effect on reactivity caused by graphite temperature change during a transient is much less than caused by the greater magnitude fuel temperature change. The effect of graphite temperature during a transient is unimportant because of its relatively long relaxation time.

The magnitude and sign of the graphite contribution to temperature coefficient is a sensitive function of the exact dimensions of the reactor, particularly the lattice spacing. The delayed graphite temperature coefficient contribution to the overall temperature coefficient of reactivity may be either slightly 
negative or slightly positive, according to the lattice spacing selected in the final reactor design. Whatever the sign of this contribution to the temperature coefficient, the overall steady-state reactor power coefficient of reactivity is negative.

\section{ULTIMATE SHUTDOWN MECHANISM}

.The melting of fuel elements and the subsequent dropping of fuel out of the central core region provides an effective shutdown mechanism during a maximum conceivable accident in which the protective system is assumed not to function to stop a large power increase. Melting of the steel fuel jackets would be necessary in only a small proportion of the total number of fuel elements in order to ensure shutdown. Even under such an extreme condition, no significant pressure rise would occur in the reactor core tank.

\section{E. TRANSIENTS}

\section{CAUSE AND PREVENTION}

In any nuclear power plant there are some possible off-normal conditions which may insert transients into the system. Such transients could be damaging to the system if not controlled, because of excessively high temperatures or thermal shock caused by rapid temperature changes. There are three general accidents by which transient conditions could be initiated:

(a) Failure of the plant automatic control system, such as by a failure of the neutron flux controller, in a manner which would cause continuous withdrawal of the control-safety rod.

(b) Manual misoperation, such as an improper manual reduction in sodium coolant flow rate while on manual flow control.

(c) Equipment failure, such as by a sudden reduction in sodium coolant flow rate caused by failure of a sodium circulation pump.

The reactor plant protective system is designed to protect the reactor from damage which could otherwise occur from such accidents. The relationship between set points, time response, and shutdown rates for the protective system is such that power is reduced before any damage caused by high temperatures or thermal shock occurs. Operator action, generally taken before protective-system action is necessary, further serves to prevent damage.

\section{TRANSIENTS}

\section{a. Rod Withdrawals}

Two general types of rod-withdrawal accidents are possible:

(1) Continuous rod withdrawal from full power at operating temperature conditions.

(2) Continuous rod withdrawal from a shutdown power level (startup accident).

\section{b. Accident from Full Power}

Withdrawal of a control-safety rod while the reactor is at full power would result in a transient. The rate of reactivity insertion associated with this transient is limited by the maximum speed of rod withdrawal. If the safety system fails and no scram occurs, melting of a portion of the fuel elements would shut down the reactor.

\section{c. Startup Accident}

Continuous withdrawal of control-safety rods from a shutdown condition, such as may conceivably occur when the reactor is being brought to a critical condition from source level, is commonly called a startup accident. The protective-system parameters are sized so as to prevent damage to the reactor during this kind of accident. However, if protective-system action should not occur and the rods were continuously withdrawn with no operator action to stop the withdrawal or initiate a scram, the reactor would be on a short period when it reaches the normal operating power range. If no scram occurs, melting of a portion of the fuel elements would occur.

\section{COOLANT FLOW ACCIDENT}

During operation at full power and full temperature, a change in coolant flow rate changes reactor temperatures rapidly. A failure of a coolant pump or a misoperation of the sodium flow controls (from either manual or automatic malfunction) could produce significant changes in fuel-element and sodiumcoolant temperatures in the fuel channels. Such changes may occur rapidly, as in the case of a complete loss of coolant flow, or slowly as from improper operation of a flow controller. The protective system is designed to prevent such occurrences from causing serious damage.

\section{SODIUM-INLET TEMPERATURE TRANSIENTS}

If a failure should occur in the external heat removal system, inlet temperature transients to the reactor could result. The plant protective system would automatically take corrective action in this event. It would remove the affected loops from operation before any serious transients reached the reactor inlet. However, if protective system and operator action failed to prevent a high inlet temperature, the increasing core temperatures would reduce reactor power. There would be no hazardous effects from this type of transient.

\section{F. RADIATION HAZARD CONTROL}

\section{OPERATIONAL EXPOSURE TO IONIZING RADIATION}

All areas which could constitute a radiation hazard to operating personnel are shielded to maintain routine exposures at less than $0.75 \mathrm{mrem} / \mathrm{hr} \quad(1.5$ rem/year). The International Committee on Radiation Protection (ICRP) advises that $5.0 \mathrm{rem} /$ year 
should not be exceeded for long-term exposures, when averaged over a 10 -year period.

\section{CONTROL OF GASEOUS AND PARTICULATE} RADIOACTIVE MATERIAL

All areas containing radioactive gas or contaminants are provided with gas seals to ensure against leakage to the reactor room or other routinely occupied areas. All systems are operated at low pressures, thereby minimizing both the causes and the effects of leakage to adjacent areas.

Gases which are normally radioactive are piped directly to shielded gas holdup tanks. Gases which are normally not radioactive are monitored before release to the atmosphere or to the gas holdup tanks as determined by the radiation level. The radioactive vent system which handles these gases was further described in section IV.

From the gas holdup tanks representative samples are obtained and analyzed for radioactive constituents. Gas is retained in the tanks for sufficient time to permit the maximum practical decay. It is then released to the atmosphere at a controlled rate. Automatic radiation detection equipment measures and records all releases of radioactive material. Design of gas holdup tanks is based on a rate of release which will meet the requirements of ICRP regulations.

In addition to the gas handling systems, the reactor area of the building is equipped with automatic air and gas monitoring devices which actuate an alarm system in the event abnormal radiation levels are detected. The building ventilation system is designed to cope with any eventualities such as a leaky gas line, rupture of a gallery seal, or spillage of small quantities of radioactive sodium. Pressure differentials between areas are designed to minimize the spread of contamination and facilitate the control of any possible leakage of radioactive material to the building atmosphere.

\section{RADIOACTIVE LIQUID WASTE}

Radioactive liquid waste is piped to a series of liquid holdup tanks where representative samples are obtained and analyzed for radioactivity content. The major portion of radioactive liquid waste originates from the reactor small-equipment cleaning cells and contains primarily $\mathrm{Na}^{24}$ which decays with a $15-\mathrm{hr}$ half-life. Liquid waste is stored for a decay period necessary to reduce the activity contributed by shortlived isotopes. It is then released, at a controlled rate, to the condenser circulating-water discharge, utilizing this available large dilution to maintain final concentrations below those advised by the ICRP. Storage space is provided for the limited quantities of liquid waste which may contain long-lived isotopes in quantities greater than that which may be released to the condenser circulating-water discharge. The radioactive-liquid-waste system was further described in section IV.

\section{EMERGENCY PROCEDURES AND RECOMMENDATIONS}

There is no single emergency procedure which is suitable for all conditions, locations, and incidents. Because of the nature of the reactor design, which includes a low-pressure system with radioactivity completely contained and separated from working areas, no emergency is anticipated which would require evacuation of the building or surrounding area. There are, however, some general factors in planning and design which are desirable to follow and apply for protection in the event of unforeseen emergency circumstances. Following is a brief outline of these factors.

\section{a. Building Evacuation Routes}

Emergency doors and road access are to be planned to facilitate evacuation.

\section{b. Alarm System}

An automatic alarm system is to be provided to warn all personnel in the event an incident should occur.

\section{c. Exclusion Area}

A prohibited area is recommended to be cleared of all dwellings for $\sim 200$ yd distance in all directions from the power-plant building.

\section{d. Emergency Plan}

An emergency plan and evacuation procedure should be developed and tested on site. This plan should include the following:

(1) Determination of an evacuation area, if necessary, according to the nature of the particular incident

(2) Traffic plan

(3) Methods of decontaminating exposed personnel

(4) Use of protective clothing

(5) Environmental monitoring

\section{ECONOMICS}

\section{A. POWER GENERATING COSTS}

The power generating costs for the 256-Mwe ASGR are estimated to be 6.70 mills $/ \mathrm{kwh}$ (Table VI). This estimate is based upon a plant factor of $80 \%$, annual fixed charges of $14 \%$, and a net plant thermal efficiency of $42.3 \%$. This estimate is in accordance with AEC specified methods of cost computation $^{13}$ for the DRD 10-year Reactor Program Study. 
TABLE VI

256-MWE ADVANCED SODIUM GRAPHITE REACTOR ESTIMATED POWER GENERATING COSTS

\begin{tabular}{l|r|l}
\hline & \multicolumn{1}{|c|}{$\begin{array}{r}\text { Mills/ } \\
\text { kwh }\end{array}$} \\
\hline Fixed charges & $\$ 8,320,000$ & 4.64 \\
Fuel-cycle cost & $2,984,000$ & 1.67 \\
Operation and maintenance & 702,000 & 0.39 \\
\cline { 2 - 3 } & $\$ 12,006,000$ & 6.70 \\
\hline
\end{tabular}

\section{B. CAPITAL INVESTMENT}

The total direct construction costs for the 256-Mwe ASGR is estimated to be $\$ 38,375,000$. With indirect construction costs, contingency, and interest during construction added, the total capital cost, without escalation, is estimated to be $\$ 59,426,000$ or $\$ 232$ per net electrical kilowatt of capacity. The fuel handling equipment and the high voltage transformer are included in the estimate. Estimated costs of major items of equipment are based upon quotations or estimates from responsible manufacturers or accumulated data from previous projects. A summary of estimated costs is shown in Table VII.

TABLE VII

256-MWE ADVANCED SODIUM GRAPHITE REACTOR CAPITAL-COST ESTIMATE

1. Land and Land Rights

$\$ 360,000$

II. Structures and Improvements

A. Site Preparation and Improvements

B. Structures, Shielding and Services

1. Excavation

2. Substructure

3. Biological shielding (included in B-2)

4. Superstructure

5. Services

C. Waste Area and Guard Building

Total, Structures and Improvements

III. Reactor Plant Equipment

A. Reactor

1. Reactor structure and containment

2. Reactivity control (control-safety rods and drives)

Subtotal III-A, Reactor

B. Auxiliary Heating

C. Moderator

D. Fuel Handling and Storage

E. Radioactive Waste Treatment and Disposal

F. Instrumentation and Control

1. Reactor-safety and nuclear-instrument system

2. Waste System

3. Radiation monitoring system

Subtotal III-F Instrument and Control

Total, Reactor Plant Equipment
$\$ 527,000$

66,000

710,000

$2,665,000$

$1,044,000$

$\$ 4,485,000$

44,000

$\$ 5,056,000$
$3,601,000$

600,000

$4,201,000$

135,000

457,000

801,000

103,000

148,000

63,000

89,000

300,000 


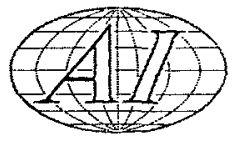

\section{TABLE VII (Continued)}

IV. Heat-Transfer System

A. Reactor Coolant System:

1. Main pumps (primary and secondary)

$\$ 2,156,000$

354,000

2. Piping

140,000

3. Valves

$1,525,000$

4. Intermediate heat exchangers

325,000

5. Initial load of sodium

358,000

6. Pipe heating system

Subtotal IV-A, Reactor Coolant System

$\$ 4,858,000$

B. Coolant Supply and Treatment

1. Sodium service system (charge and discharge purification, sampling)

510,000

54,000

2. Inert-gas system

240,000

3. Cooling system

Subtotal IV-B, Coolant Supply and Treatment

$\$ 804,000$

$5,680,000$

C. Steam Generating System

$1,900,000$

E. Instrumentation

1. Primary plant control

578,000

2. Heat-transfer system

24,000

3. Steam generator system

Subtotal IV-E, Instrumentation

28,000

$\$ 630,000$

Total, Heat Transfer System

$\$ 13,872,000$

V. Turbine-Generator System

A. Turbine-Generator and Auxiliaries

$8,500,000$

B. Condenser and Water System

$1,919,000$

C. Instrumentation and Control

30,000

Total, Turbine-Generator System

VI. Accessory Electrical Equipment

VII. Miscellaneous Power Plant Equipment

Total, Direct Construction Cost

VIII. Indirect Construction Cost

A. General and Administration

$\$ 4,797,000$

$6,303,000$

B. Engineering, Design, and Inspection

500,000

C. Startup Costs

$11,600,000$
$\$ 49,975,000$
$4,998,000$
-
$4,453,000$
$\$ 59,426,000^{\circ}$

Total Capital Cost

Total, Installed Cost Per kw: $\$ 232 /$ kw. 


\section{FUEL CYCLE COSTS}

The costs involved in the sequence of steps beginning with the acquisition of the $\mathrm{UF}_{6}$ from the AEC and ending (after processing of the spent fuel) with the return to the AEC of the remaining uranium and plutonium for credit have been estimated to be $\$ 288.40 / \mathrm{kg}-\mathrm{U}$ or $1.67 \mathrm{mills} / \mathrm{kwh}$. This cost determination is summarized in Table VIII and is based upon the following criteria:
(1) Average fuel exposure of 17,100 $\mathrm{Mwd} / \mathrm{MTU}$

(2) Net plant efficiency of $42.3 \%$.

(3) AEC price schedule for enriched uranium.

(4) Annual uranium lease charge of $4 \%$.

(5) Plutonium credit of $\$ 12 / \mathrm{gm}$.

(6) Reprocessing and fuel recovery charges as estimated for the "AEC Reference Fuel Processing Plant."

TABLE VIII

256-MW ADVANCED SODIUM GRAPHITE REACTOR FUEL-CYCLE COSTS

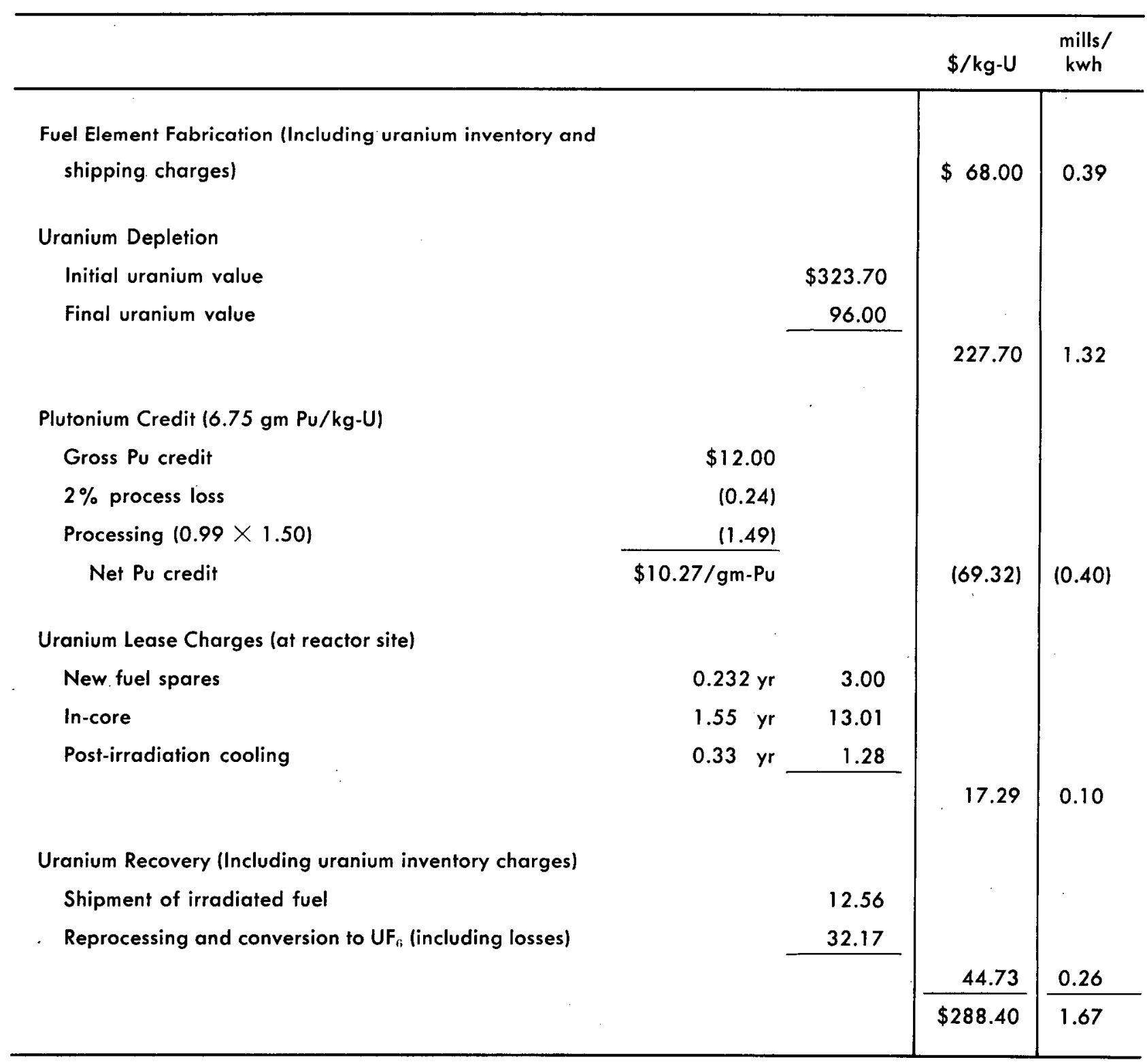



TABLE IX (Continued)

\begin{tabular}{|c|c|c|}
\hline No. Req'd. & Item & Rating \\
\hline 1 & Gland-seal condenser & furnished with turbine-generator \\
\hline 2 & Turbine lube-oil coolers & furnished with turbine-generator \\
\hline 3 & Feedwater-pump-oil coolers & furnished with boiler feed pump \\
\hline 2 & Instrument-air after coolers & furnished with compressors \\
\hline \multirow[t]{2}{*}{2} & Service-air after coolers & furnished with compressors \\
\hline & Pumps and Compressors & \\
\hline 9 & Primary sodium pumps (EM) & $3400 \mathrm{gpm}, 110-\mathrm{ft}$ head \\
\hline 3 & Secondary sodium pumps (EM) & $10,200 \mathrm{gpm}, 110-\mathrm{ft}$ head \\
\hline 1 & Primary service pump (EM) & $100 \mathrm{gpm}, 100-\mathrm{ft}$ head \\
\hline 1 & Secondary service pump (EM) & $100 \mathrm{gpm}, 100-\mathrm{ft}$ head \\
\hline 2 & Reactor drain pumps (EM) & $50 \mathrm{gpm}, 100-\mathrm{ft}$ head \\
\hline 1 & Sodium transfer (EM) & $100 \mathrm{gpm}, 100-\mathrm{ft}$ head \\
\hline 1 & Liquid-waste transfer pump & $5 \mathrm{gpm}, 70-\mathrm{ft}$ head \\
\hline 1 & Vacuum pump & $\begin{array}{l}10 \mathrm{ft}^{3} \text { in } 10 \mathrm{~min} \\
0.1 \mathrm{~mm} \mathrm{Hg}\end{array}$ \\
\hline 1 & Control volume pump & $1 \mathrm{gpm}, 40-\mathrm{ft}$ head \\
\hline 1 & Oil pump & $200 \mathrm{gpm}, 75-\mathrm{ft}$ head \\
\hline 2 & Reactor-plant cooling-water pumps & $600 \mathrm{gpm}, 150-\mathrm{ft}$ head \\
\hline 3 & Boiler feed pumps & $\begin{array}{l}1,000,000 \mathrm{lb} / \mathrm{hr} \\
5900 \mathrm{ft} \mathrm{T.} \mathrm{H.}\end{array}$ \\
\hline 1 & Emergency boiler feed pump & $250 \mathrm{gpm}, 2800$ psig \\
\hline 3 & Condensate pumps & $1500 \mathrm{gpm}, 400-\mathrm{ft}$ head \\
\hline 1 & Emergency condensate pump & $200 \mathrm{gpm}$ \\
\hline 2 & Circulating water pumps & $117,000 \mathrm{gpm}, 20-\mathrm{ft}$ head \\
\hline 1 & Emergency circulating water pump & $3500 \mathrm{gpm}, 20-\mathrm{ft}$ head \\
\hline 1 & Boiler hydroset pump & 5 gpm, 3600 psig \\
\hline 2 & Bearing lube water pumps & $40 \mathrm{gpm}, 300-\mathrm{ft}$ head \\
\hline 3 & Service water pumps & $3500 \mathrm{gpm}, 75-\mathrm{ft}$ head \\
\hline 1 & Emergency service water pump & $350 \mathrm{gpm}, 75-\mathrm{ft}$ head \\
\hline 2 & Station cooling water pumps & $250 \mathrm{gpm}, 100-\mathrm{ft}$ head \\
\hline 1 & Diesel fire pump & 1000 gpm, 240 psig \\
\hline 1 & Jockey fire pump & $50 \mathrm{gpm}, 230$ psig \\
\hline 1 & Screen refuse pump & 2000 gpm, 30 psig \\
\hline 2 & Domestic water supply pumps & $30 \mathrm{gpm}, 115$ pgis \\
\hline 1 & ac lube-oil pump & furnished with turbine-generator \\
\hline 1 & dc lube-oil pump & furnished with turbine-generator \\
\hline 1 & Turning-gear lube-oil pump & furnished with turbine-generator \\
\hline 1 & ac seal oil pump & furnished with turbine-generator \\
\hline 1 & dc seal oil pump & furnished with turbine-generator \\
\hline 1 & Lube-oil filter pump & furnished with turbine-generator \\
\hline 1 & Lube-oil transfer pump & furnished with turbine-generator \\
\hline 1 & Service air compressor & $200 \mathrm{cfm}, 150$ psig \\
\hline 2 & Instrument air compressors & $240 \mathrm{cfm}, 100 \mathrm{psig}$ \\
\hline 2 & Radioactive vent system compressors & $25 \mathrm{cfm}, 150$ psig \\
\hline 4 & Primary fill tanks & $5000 \mathrm{ft}^{3}$ \\
\hline 2 & Secondary fill tanks & $5000 \mathrm{ft}^{3}$ \\
\hline 3 & Secondary expansion tanks & $350 \mathrm{ft}^{3}$ \\
\hline
\end{tabular}


TABLE IX (Continued)

\begin{tabular}{|c|c|c|}
\hline No. Req'd. & Item & Rating \\
\hline 1 & Primary-service-system drain tank & $10 \mathrm{ft}^{3}$ \\
\hline 1 & Secondary-service-system drain tank & $10 \mathrm{ft}^{3}$ \\
\hline 1 & Sodium transfer tank & $20 \mathrm{ft}^{3}$ \\
\hline 1 & Sodium-melt-station oil supply tank & $750 \mathrm{gal}$ \\
\hline$i$ & Helium low-pressure storage tank & $4 \mathrm{ft}^{3}$ \\
\hline 1 & Nitrogen low-pressure storage tank & $100 \mathrm{ft}^{3}$ \\
\hline 1 & Vent-system-compressor suction tank & $200 \mathrm{ft}^{3}$ \\
\hline 2 & Vent system decay tanks & $320 \mathrm{ft}^{3}$ \\
\hline 1 & Calandria pump-out tank & $500 \mathrm{gal}$ \\
\hline 1 & Radioactive waste transfer tank & $50 \mathrm{gal}$ \\
\hline 1 & Chemical storage tank & $65 \mathrm{gal}$ \\
\hline 2 & Radioactive waste storage tanks & $2500 \mathrm{gal}$ \\
\hline 1 & Wash-cell evaporated-water storage tank & $50 \mathrm{gal}$ \\
\hline 2 & Condensate storage tanks & $50,000 \mathrm{gal}$ \\
\hline 1 & Domestic water accumulator & $2000 \mathrm{gal}$ \\
\hline 1 & Fire-system accumulator & $700 \mathrm{gal}$ \\
\hline 1 & Jockey pump supply tank & $300 \mathrm{gal}$ \\
\hline 1 & Stạtion cooling-water return tank & $3500 \mathrm{gal}$ \\
\hline 1 & Wall water storage tank & $150,000 \mathrm{gal}$ \\
\hline 1 & Diesel-oil storage tank & $10,000 \mathrm{gal}$ \\
\hline 1 & Warmup expansion tank & $25 \mathrm{ft}^{3}$ \\
\hline 2 & Instrument air receivers & $100 \mathrm{ft}^{3}$ \\
\hline 1 & Service air receivers & $100 \mathrm{ft}^{3}$ \\
\hline 1 & Fire system air receivers & $700 \mathrm{gal}$ \\
\hline 1 & Lube-oil reservoir & $10,000 \mathrm{gal}$ \\
\hline 1 & Lube-oil filter tank & $650 \mathrm{gal}$ \\
\hline 1 & Clean lube-oil storage tank & $12,000 \mathrm{gal}$ \\
\hline \multirow[t]{2}{*}{1} & Dirty lube-oil storage tank & $12,000 \mathrm{gal}$ \\
\hline & Fuel Handling & \\
\hline 1 & Fuel handling cask and gantry crane & \\
\hline 260 & Spent-fuel storage cell and plugs & \\
\hline 1 & Washing cell and plug & \\
\hline 3 & Fuel preheat cells and plugs & \\
\hline 17 & Spent-fuel shipping casks & \\
\hline 170 & New-fuel shipping containers & \\
\hline \multirow[t]{2}{*}{17} & New-fuel storage racks & \\
\hline & Miscellaneous Equipment & \\
\hline 1 & Intermediate-heat-exchanger storage cell & \\
\hline 12 & $\begin{array}{l}\text { Miscellaneous-components storage cell (orifice tubes, } \\
\text { fuel element shield plug, and hanger rod) }\end{array}$ & \\
\hline 18 & Control-safety rod storage cell & \\
\hline 1 & Fuel-handling-cask service pit & \\
\hline 1 & Reactor-area bridge crane & $\begin{array}{l}\text { overhead traveling bridge, } 30 \text {-ton } \\
\text { capacity, } 66 \text {-ft span }\end{array}$ \\
\hline 1 & Reactor-auxiliary-bay bridge crane & $\begin{array}{l}\text { overhead traveling bridge, } 75 \text {-ton } \\
\text { capacity, } 90 \text {-ft span }\end{array}$ \\
\hline
\end{tabular}


TABLE IX (Continued)

\begin{tabular}{|c|c|c|c|}
\hline No. Req'd. & Item & & Rating \\
\hline 1 & Makeup-water evaporator system & - & \\
\hline 1 & Primary-sodium-loop cold-trap assembly & & \\
\hline 1 & Secondary-sodium-loop cold-trap assembly & & \\
\hline 2 & Plugging meter assemblies & & \\
\hline 1 & Air ejector & & furnished with condenser \\
\hline 1 & Auxiliary boiler & & $15 \times 10^{6}$ BTU per hour \\
\hline 1 & Instrument air dryer & & \\
\hline 4 & Traveling water screens & & $46,000 \mathrm{gpm}$ \\
\hline 2 & Sodium drum heaters & & $3 \mathrm{kw}$ \\
\hline 2 & Sodium filters & & \\
\hline 8 & Vapor traps & & \\
\hline 7 & Freeze traps & & \\
\hline 8 & Radioactive dust filters & & \\
\hline 1 & Radioactive-waste transfer set & & $10 \mathrm{gpm}$ \\
\hline 1 & Helium manifold & & 2400 psig/50 psig \\
\hline 1 & Calandria drain eductor & & $10 \mathrm{gpm}$ \\
\hline 1 & Nitrogen moisture absorber & & \\
\hline 1 & Helium moisture absorber & & \\
\hline 1 & Sodium-service-area monorail crane & & 7-ton capacity \\
\hline 1 & Hogging ejector & & furnished with condenser \\
\hline 4 & Intake structure trash rakes & & \\
\hline 1 & Intake structure trash rake rack & & \\
\hline 1 & River water chlorinator & & $\begin{array}{l}\text { including evaporator, heaters, chlori- } \\
\text { nator, valves, control panel, chlorine } \\
\text { pumps }\end{array}$ \\
\hline 1 & Service water basket strainer & & $6500 \mathrm{gpm}$ \\
\hline El & $\begin{array}{l}\text { Domestic water chlorinator } \\
\text { ectrical Equipment }\end{array}$ & & $30 \mathrm{gpm}$ \\
\hline 1 & Main power transformer & & $\begin{array}{l}\text { 320-mva, 3-phase, } 60 \text {-cycle 138-kv, } \\
\text { gnd } Y-24 \mathrm{kv} \Delta, \text { FOA, } 550 \mathrm{kv} \text { BIL }\end{array}$ \\
\hline 1 & Reserve power transformer & & $\begin{array}{l}\text { 12.5-mva, 3-phase, 60-cycle, 138-kv- } \\
4160 Y / 2400-4160 Y / 2400-v, \text { FOA, } \\
550-\mathrm{kv} \text { BIL }\end{array}$ \\
\hline 1 & Main generator & & see Major Equipment List \\
\hline 1 set & Isolated phase bus & & 24-kv, 8000-amp, aluminum \\
\hline 1 & Auxiliary power transformer & & $\begin{array}{l}\text { 12.5-mva, 3-phase, 60-cycle; 24-kv- } \\
4160 \mathrm{Y} / 2400-4160 \mathrm{Y} / 2400-\mathrm{v} ; \text { FOA; } \\
110-\mathrm{kv} \text { BIL }\end{array}$ \\
\hline 1 set & Isolated phase bus & & 24-kv, 600-amp bus \\
\hline 1 assembly & Outdoor switchgear & & $\begin{array}{l}5 \text {-kv, 2000-amp bus; } 250 \text {-mva I. C. } \\
\text { breakers }\end{array}$ \\
\hline 2 sets & Indoor, double-ended, $480-v$ unit load centers & & $\begin{array}{l}1500-\text { kva }(750 \text { each end) } 1200 \text {-amp } \\
\text { bus; } 50,000 \text {-amp I. C. breakers }\end{array}$ \\
\hline 6 assemblies & $480-v$ control centers & & $\begin{array}{l}\text { plugin, drawout-type combination- } \\
\text { circuit-breaker-type starters; } 15,000 \text { - } \\
\text { amp I. C. breakers; NEMA type B } \\
\text { construction }\end{array}$ \\
\hline
\end{tabular}




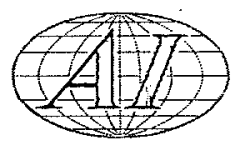

TABLE IX (Continued)

\begin{tabular}{|c|c|c|}
\hline No. Req'd. & Item & Rating \\
\hline 1 set & Excitation switchgear & furnished with generator \\
\hline 1 set & $\begin{array}{l}\text { Generator surge protection and instrument transformer } \\
\text { cubicles }\end{array}$ & $\begin{array}{l}25-\mathrm{kv} \text { arrestors, } 0.13 \mathrm{mfd}, 25-\mathrm{kv} \\
\text { capacitors; } 24,000-120-\mathrm{v}(200: 1) \\
\text { instrument potential transformers }\end{array}$ \\
\hline 1 & $\begin{array}{l}\text { Generator neutral transformer cubicle } \\
.\end{array}$ & $\begin{array}{l}75-k v a \text {, single-phase, } 13,800-480 / \\
240-v \text {, distribution-type transformer } \\
\text { and secondary resistor }\end{array}$ \\
\hline 1 & Main exciter & $\begin{array}{l}\text { shaft connected to generator; } 1150 \text { - } \\
k w, 500-v, d c, 718-\mathrm{rpm}\end{array}$ \\
\hline 1 & Spare exciter & $\begin{array}{l}\text { furnished with generator; } 1150-\mathrm{kw} \\
500-\mathrm{v}, \mathrm{dc} ; 718-\mathrm{rps}, 2000-\mathrm{hp}, 4160-\mathrm{v} \\
\text { drive motor }\end{array}$ \\
\hline 1 & Emergency generator, diesel-driven. & $\begin{array}{l}\text { 2-cycle diesel engine; } 500-\mathrm{kva} \text {, } \\
3-\text { phase, } 60-\text { cycle; } 480 / 277-v, 1800 \\
\text { rpm; automatic starting and synchro- } \\
\text { nizing }\end{array}$ \\
\hline 1 & Emergency generator furbine driven & $\begin{array}{l}\text { low-pressure impulse turbine; noncon- } \\
\text { densing-type; generator same as } \\
\text { diesel-driven unit; automatic starting } \\
\text { and synchronizing }\end{array}$ \\
\hline 9 & Linear induction $E M$ primary sodium pumps & $\begin{array}{l}3400-\mathrm{gpm}, 220-\text {, 3-phase, 15-cycle, } \\
1600-\text { amp, } 600^{\circ} \mathrm{F} \text {, drawout-type } \\
\text { construction }\end{array}$ \\
\hline 9 & Primary E M pump frequency converters. & $\begin{array}{l}4160-v, 3 \text {-phase, } 60 \text {-cycle drive; } \\
220-v, 3-\text { phase, } 15 \text {-cycle, } 250-\mathrm{kw} \text {, } \\
30 \% \text { power factor }\end{array}$ \\
\hline 9 & Frequency converter control panels & $\begin{array}{l}800 \text {-amp air circuit breakers; auto- } \\
\text { matic } 15 \text {-cycle voltage control for } \\
\text { converters }\end{array}$ \\
\hline 2 & Instrument and standby $M-G$ sets & $\begin{array}{l}\text { 30-kva, 3-phase, } 60 \text {-cycle, } 0.8 \text { power } \\
\text { factor, } 120 / 208-v \text { pure sine wave } \\
\text { output; } 40 \mathrm{hp}, 250-v \text { dc drive motor }\end{array}$ \\
\hline 1 assembly & 250-v de switchgear & $\begin{array}{l}\text { motor-control-center type; two-bus } \\
\text { arrangement }\end{array}$ \\
\hline 1 & 120 -cell reactor battery & $320 \mathrm{amp}-\mathrm{hr}$, lead-acid type \\
\hline 1 & 120-cell station battery & 460 amp-hr, lead-acid type \\
\hline 3 & Battery charging rectifiers (1 spare) & $\begin{array}{l}\text { Static, dry-type, silicon, } 480-v, 3-p h a s e \\
\text { input; } 30-k w, 260-v \text { de output; auto- } \\
\text { matic voltage control }\end{array}$ \\
\hline 4 & Reactor rod drive power supplies (1 spare) & $\begin{array}{l}\text { commutator-type, } 250-v \text { de input; } \\
10-k w, 3-p h a s e, 0 \text { to } 5 \text { cycles, } 230-v \\
\text { output }\end{array}$ \\
\hline 4 & 138-kv airblast circuit breakers & oil insulated, 5000-mva I. C. \\
\hline 2 & Metering and relaying potential transformer & $138,000 / 120 \times(1150: 1)$ \\
\hline 1 & Automatic PBX telephone switchboard & 50-line capacity \\
\hline I assembly & Carrier-current communication and relaying cubicle & $\begin{array}{l}\text { two-frequency duplex telephone com- } \\
\text { munication; single-frequency, two-way } \\
\text { relaying channel }\end{array}$ \\
\hline 1 & Fire alarm system & $\begin{array}{l}\text { single-supervised, selective-coded, } \\
\text { electrically noninterfering type }\end{array}$ \\
\hline
\end{tabular}




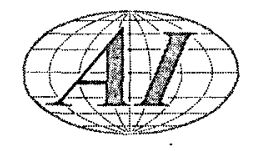

\section{REFERENCES}

1. J. B. Williams, "Design of a Calandria Core for the Sodium Reactor Experiment," NAASR-3936 (December 29, 1959)

2. J. E. Mahlmeister, "Preliminary Design of a Calandria Core for the Sodium Reactor Experiment," NAA-SR-2151 (November 15, 1957)

3. D. H. Turner and E. G. Kendall, "Fabrication of Uranium Monocarbide by Melting and Casting Methods," ANS Paper (Winter Meeting, November 4-6, 1959)

4. C. A. Smith and F. Rough, "Properties of Uranium Monocarbide," NAA-SR-3625 (June 1959)

5. R. G. Hoff, "Development of SGR Safety and Control Components," NAA-SR-4391, (to be published)

6. H. Bohl, Jr., et al., "MUFT-IV Fast Neutron Spectrum Code for the IBM-704," WAPDTM-72 (July 1957)

7. O. J. Marlowe, et al., "WANDA-A One Dimensional Few Group Diffusion Equation Code for the IBM-704," WAPD-TM-28 (November 1956)

8. O. J. Marlowe, et al., "CANDLE-A One Dimensional Few Group Depletion Code for the IBM-704," WAPD-TM-53. (May 1957)

9. R. S. Baker, "Linear Induction Pumps for the SRE Overflow Mockup," NAA-SR-4388 (January 1960)

10. J. J. Gill and J. C. Bokros, "Carburization and Nitriding of Type 304 Stainless Steel in Sodium Systems," NAA-SR-4887 (to be published)

11. Enrico Fermi Atomic Power Plant, APDA-124 (January 1959)

12. J. G. Lundholm, Jr. and C. W. Griffin, "Determination of Nuclear Parameters of the SRE by Frequency Response Measurements Utilizing Pile Oscillator Techniques," NAA-SR3763 (to be published)

13. Power Cost Normalization Studies, Civilian Power Reactor Program-1959, Report SL1674 (September 1959) 


\section{APPENDIX: FIGURES}

Figure 1. General Arrangement (section elevation) . . . . . . . . A-1

Figure 2. General Arrangement (section plan) . . . . . . . . . A-2

Figure 3. Calandria and Process-Channel Details . . . . . . . . A-3

Figure 4. Calandria Details . . . . . . . . . . . . . . . . . A-4

Figure 5. Fuel Element and Shield Plug . . . . . . . . . . . . A-5

Figure 6. Orifice Tube . . . . . . . . . . . . . . . . . . A-6

Figure 7. Ball-Latch Diagram . . . . . . . . . . . . . . . A-7

Figure 8. Reactor Cavity Arrangement (section elevation) . . . . . . A-8

Figure 9. Reactor Cavity Arrangement (section plan) . . . . . . . A-9

Figure 10. Neutron Shield Wall . . . . . . . . . . . . . . A-10

Figure 11. Reactor Vessel . . . . . . . . . . . . . . . . A-11

Figure 12. Electromagnetic Pump (lamination structure) . . . . . . . A-12

Figure 13. Electromagnetic Pump (coil support structure) . . . . . . A-13

Figure 14. Electromagnetic Pump Connections . . . . . . . . . . . . A-14

Figure 15. Intermediate Heat Exchanger . . . . . . . . . . . A-15

Figure 16. Pump and Heat-Exchanger Removal Plugs . . . . . . . A-16

Figure 17. Containment Vessel . . . . . . . . . . . . . . A-17

Figure 18. Loading-Face Shield . . . . . . . . . . . . . . A-18

Figure 19. Cooling Coils (loading-face shield) . . . . . . . . . A-19

Figure 20. Reactor (piping and instrumentation diagram) . . . . . . A-20

Figure 21. Heat-Balance Diagram . . . . . . . . . . . . . A-21

Figure 22. Heat-Transfer-System Piping (plan) . . . . . . . . . A-22

Figure 23. Heat-Transfer-System Piping (sections) . . . . . . . . A-23

Figure 24. Sodium Service System (piping and instrumentation diagram) . A-24

Figure 25. Heating Details (reactor structure) . . . . . . . . . A-25

Figure 26. Water Cooling System (piping and instrumentation diagram) . A-26

Figure 27. Inert-Gas System . . . . . . . . . . . . . . . . A-27

Figure 28. Radioactive Vent System (piping and instrumentation diagram) . A-28

Figure 29. Radioactive-Waste System (piping and instrumentation diagram) A-29

Figure 30. Fuel Handling Cask . . . . . . . . . . . . . . A-30

Figure 31. Nuclear Instrumentation . . . . . . . . . . . . . A-31

Figure 32. Plant Protective System . . . . . . . . . . . . . A-32

Figure 33. Primary Control Diagram . . . . . . . . . . . . A-33

Figure 34. Primary Power System . . . . . . . . . . . . . A-34

Figure 35. Electrical-Equipment Arrangement . . . . . . . . . A-35

Figure 36. Auxiliary Power System . . . . . . . . . . . . . A-36

Figure 37. Emergency Power System . . . . . . . . . . . . A-37

Figure 38. Plot Plan . . . . . . . . . . . . . . . . . A-38

Figure 39. Basement Floor Plan . . . . . . . . . . . . . . . . . . A-39

Figure 40. First-Floor Plan . . . . . . . . . . . . . . . A-40

Figure 41. Reactor-Component Storage . . . . . . . . . . . . A-41

Figure 42. Second-Floor Plan . . . . . . . . . . . . . . . A-42

Figure 43. Third-Floor Plan . . . . . . . . . . . . . . . A-43

Figure 44. Reactor Building (west and east elevations) . . . . . . . A-44

Figure 45. Reactor Building (south elevation) . . . . . . . . . . A-45

Figure 46. Roof Plan and North Elevation . . . . . . . . . . . A-46

Figure 47. Reactor Building (sections A-A and B-B) . . . . . . . A-47

Figure 48. Reactor Building (section C-C) . . . . . . . . . . A-48

Figure 49. Reactor Building (sections D-D, E-E, and F-F) . . . . . A-49

Figure 50. Plumbing and Fire-Protection Systems (basement, first-floor plans) A-50

Figure 51. Plumbing and Fire-Protection Systems (second-floor plan) . . A-51

Figure 52. Plumbing and Fire-Protection Systems (third-floor plan) . . . A-52

Figure 53. Heating and Ventilating Flow Diagram . . . . . . . . A-53

Figure 54. Heating and Ventilating Layout (basement and first-floor plan) . A-54

Figure 55. Heating and Ventilating Layout (second-floor plan) . . . . A-55

Figure 56. Heating and Ventilating Layout (third-floor plan) . . . . . A-56 


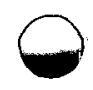

\section{.}
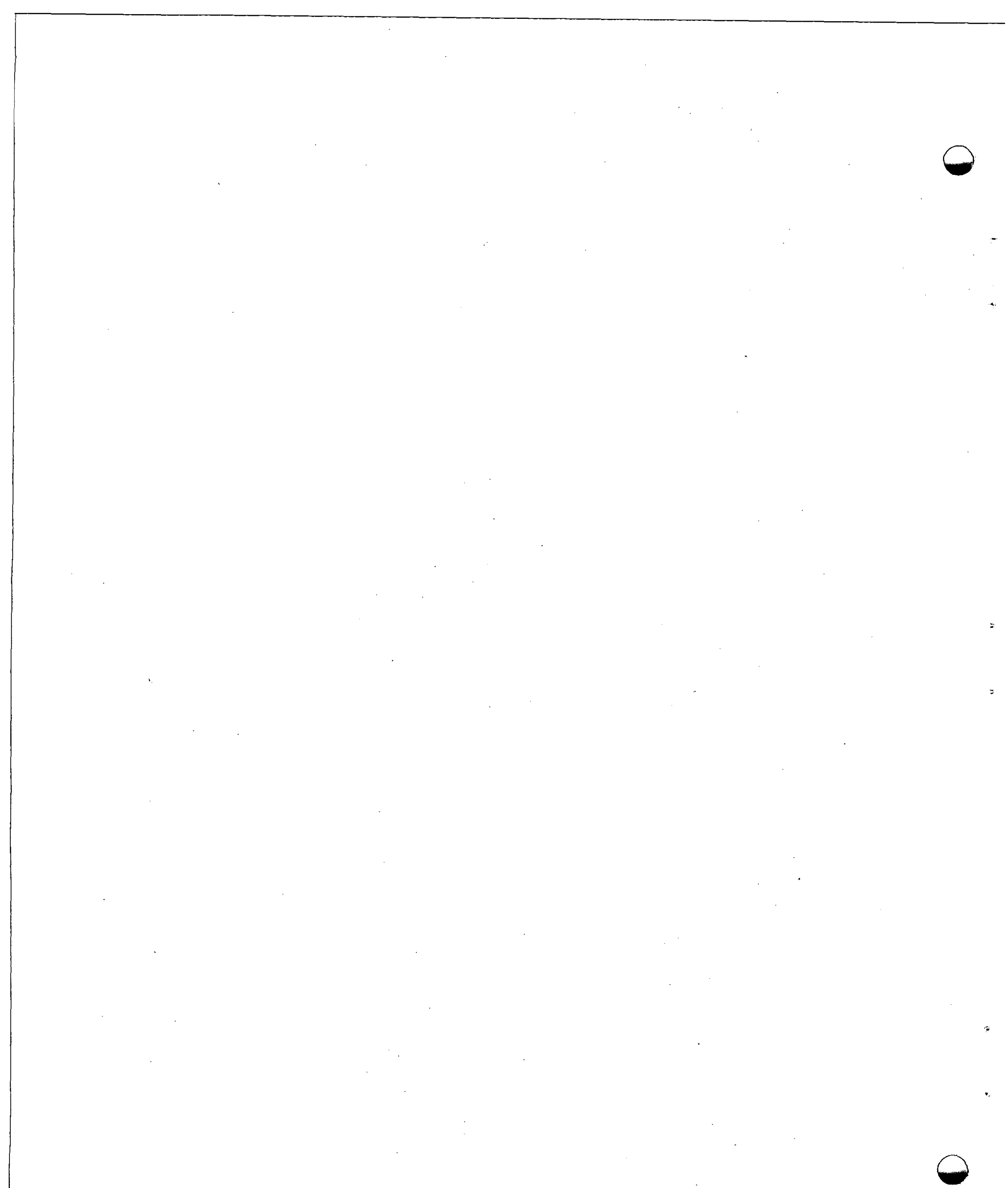

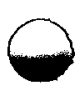



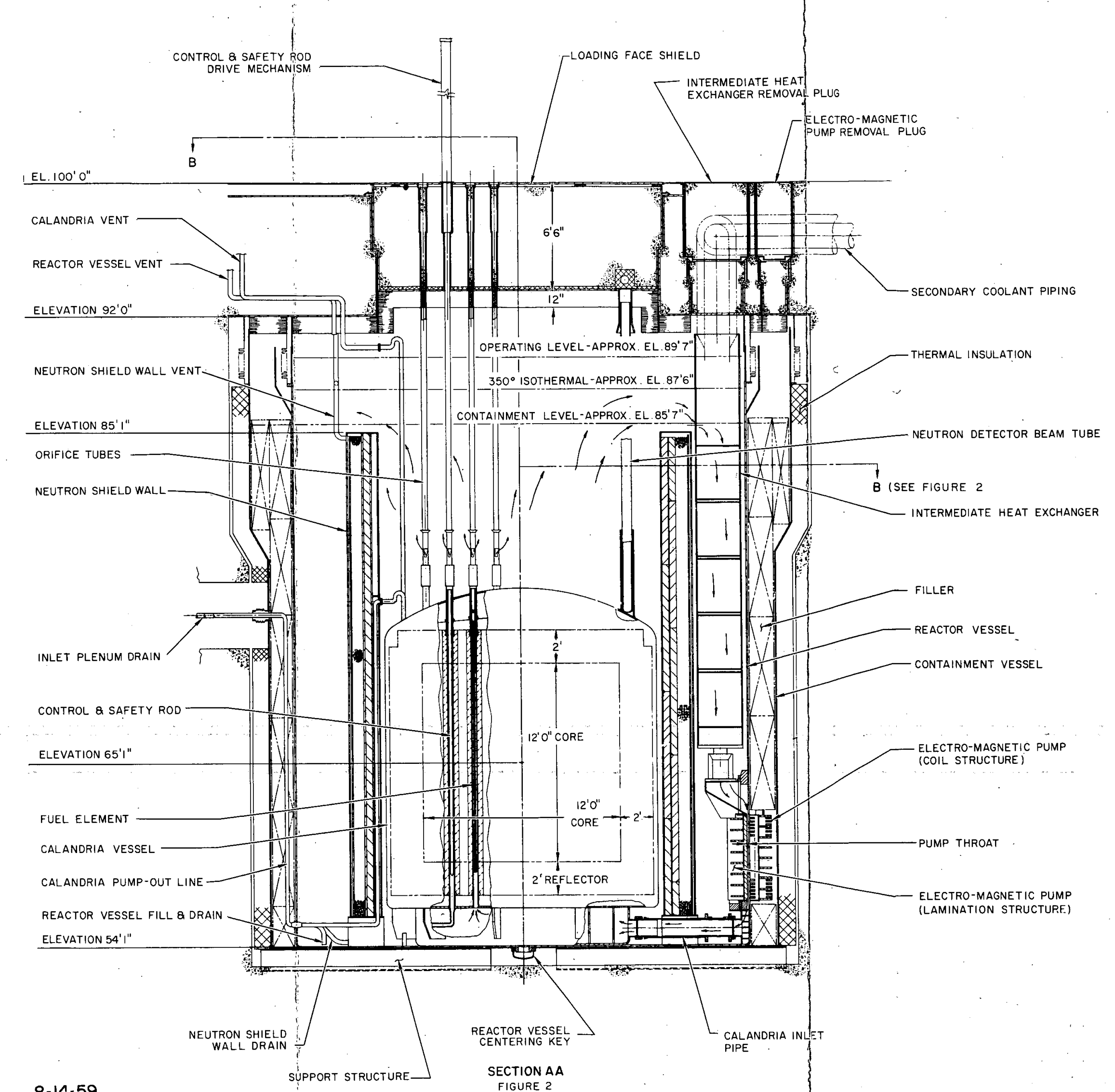

8-14-59

SUPPORT STRUCTURE_ SECTION AA
FIGURE 2 


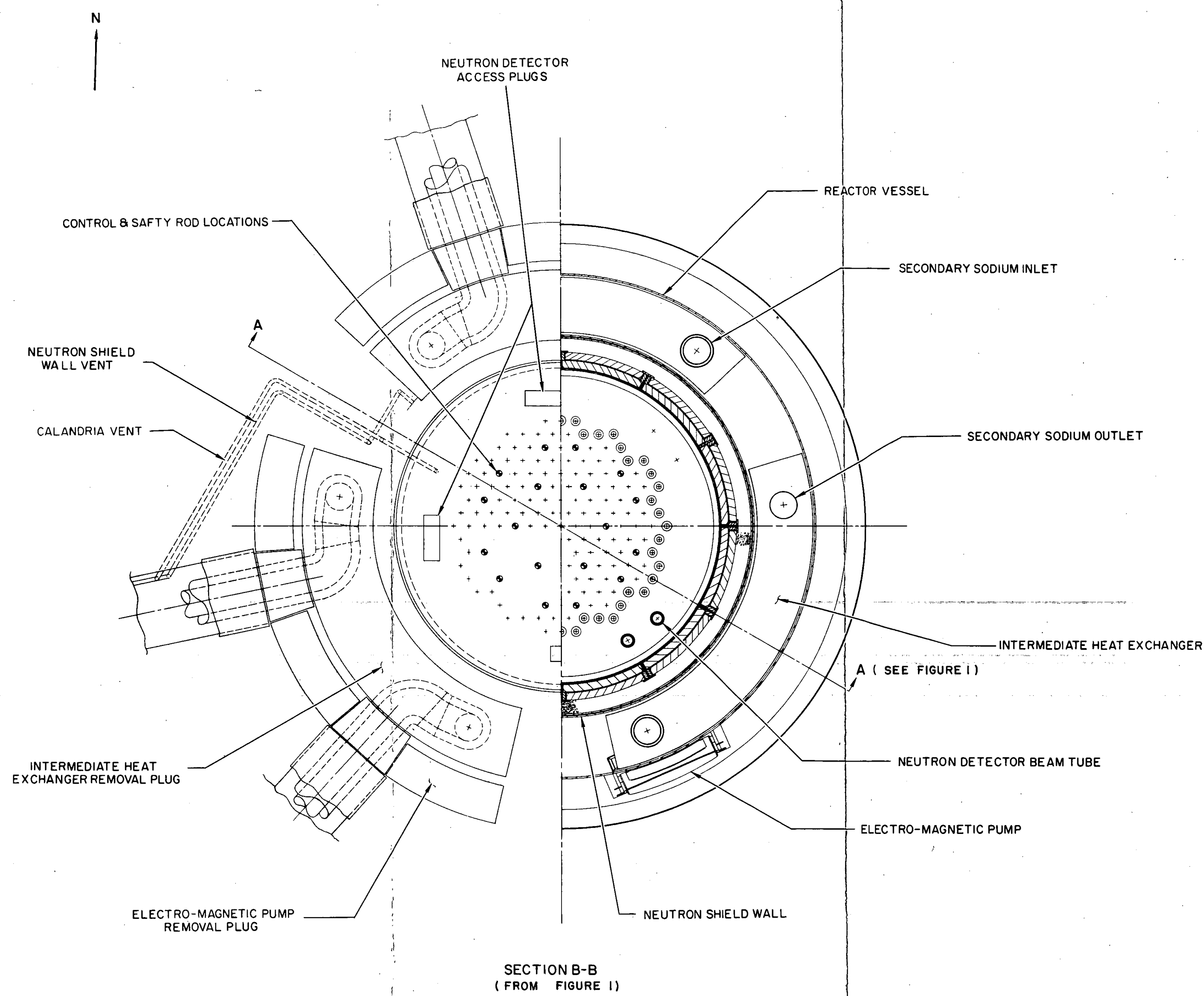

(FROM FIGURE I) 


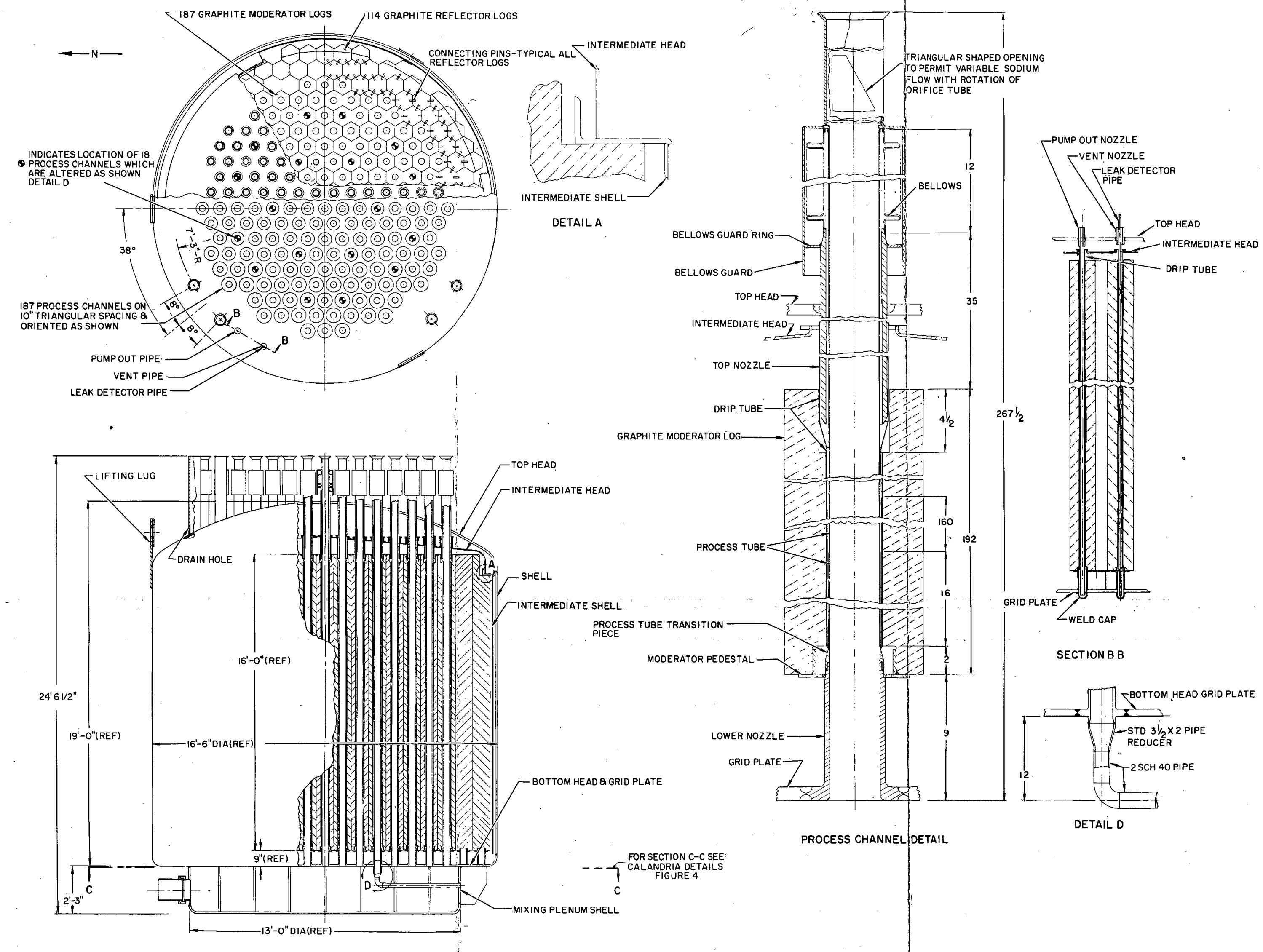




\section{O}

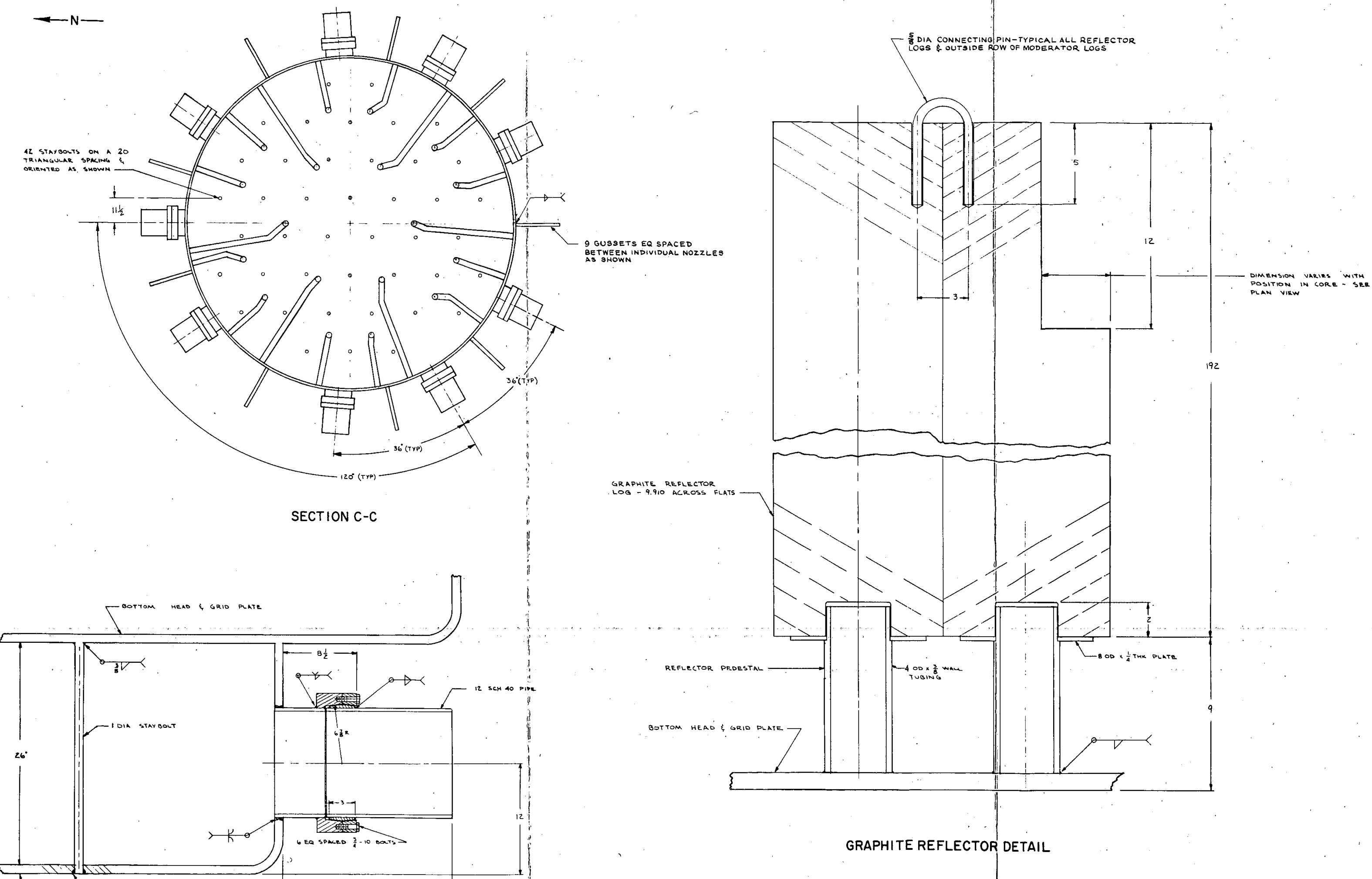




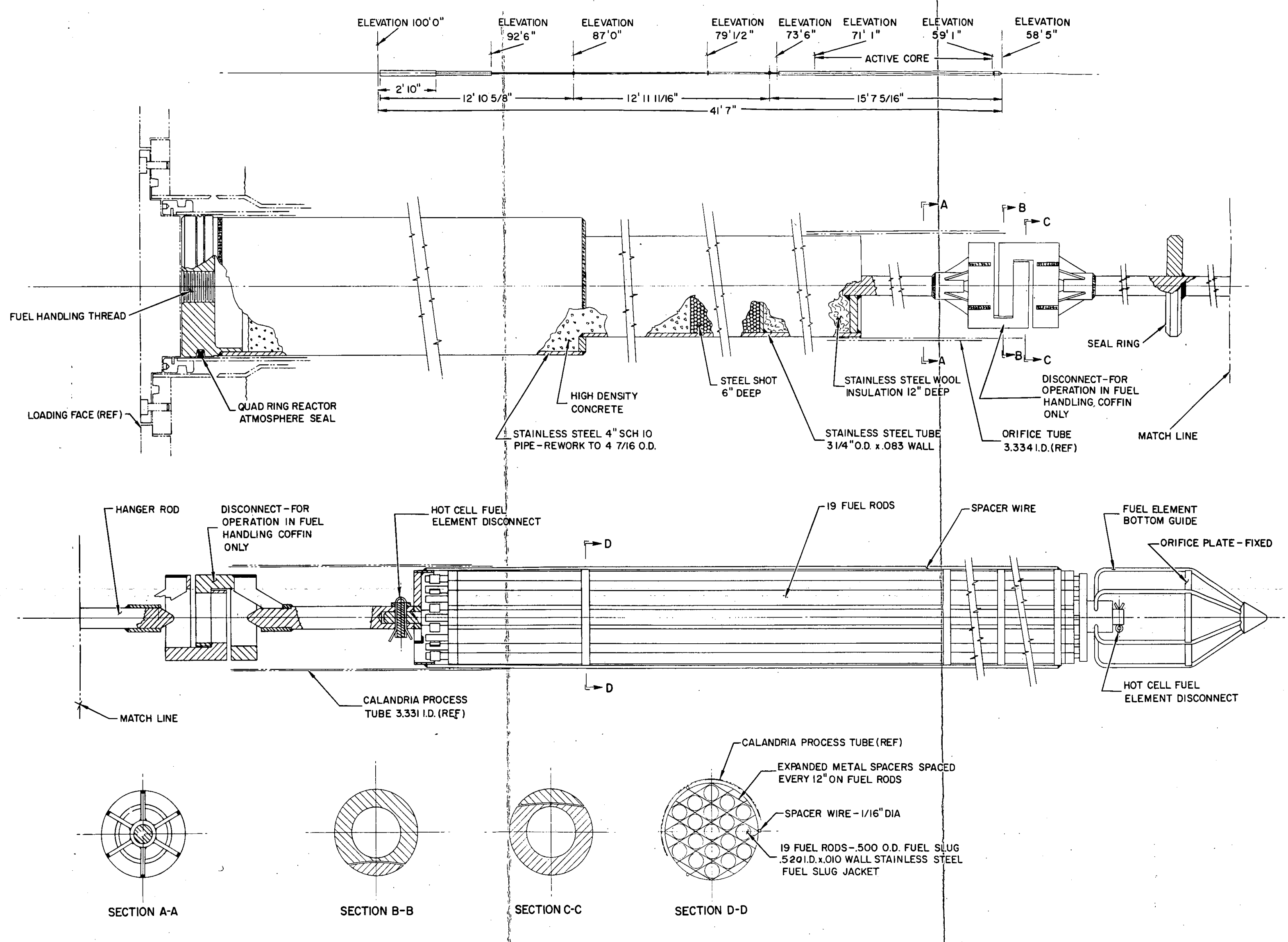

Figure 5. Fuel Element and Shield Plug 


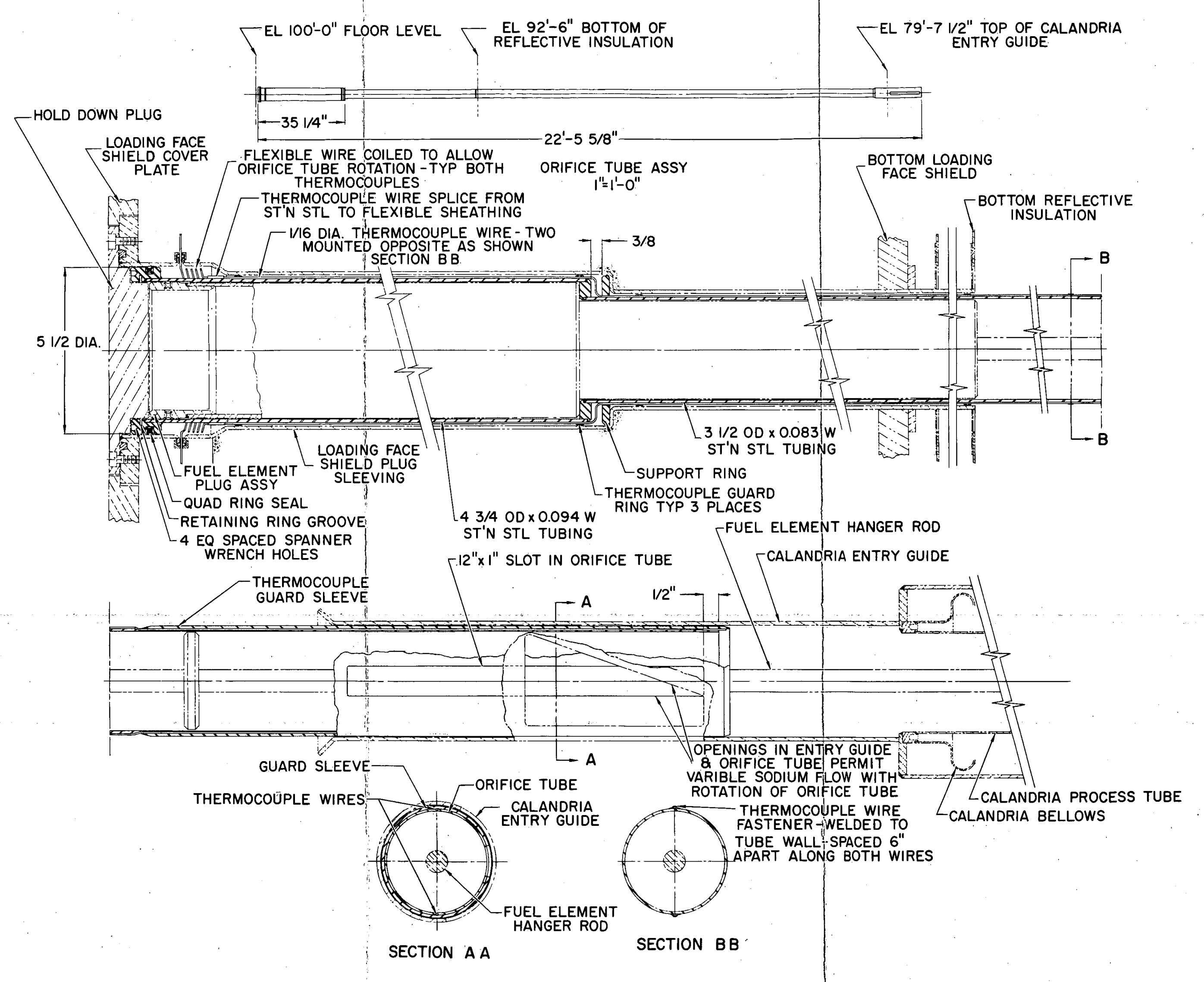

Figure 6. Orifice Tube 

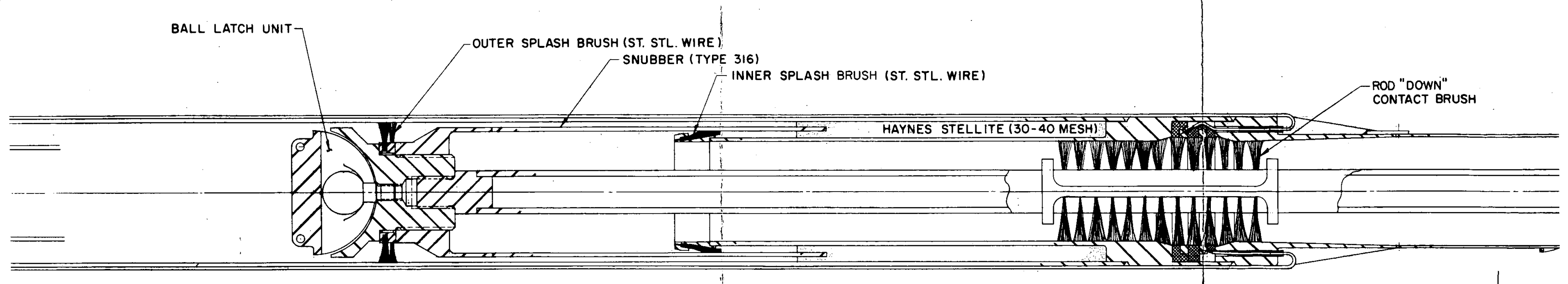

1

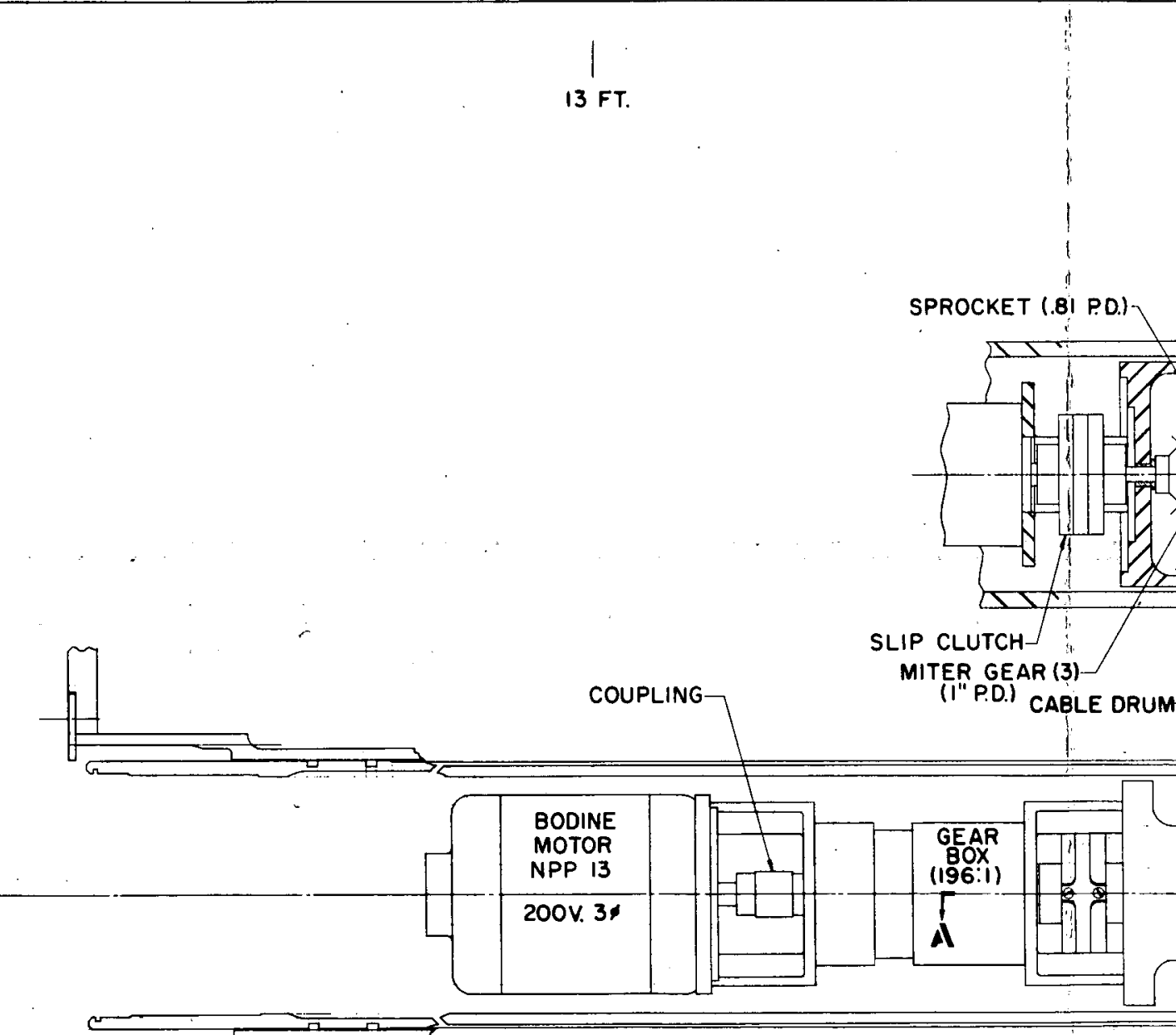

$\left.\right|_{14 \mathrm{FT}}$

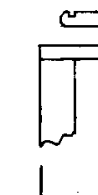




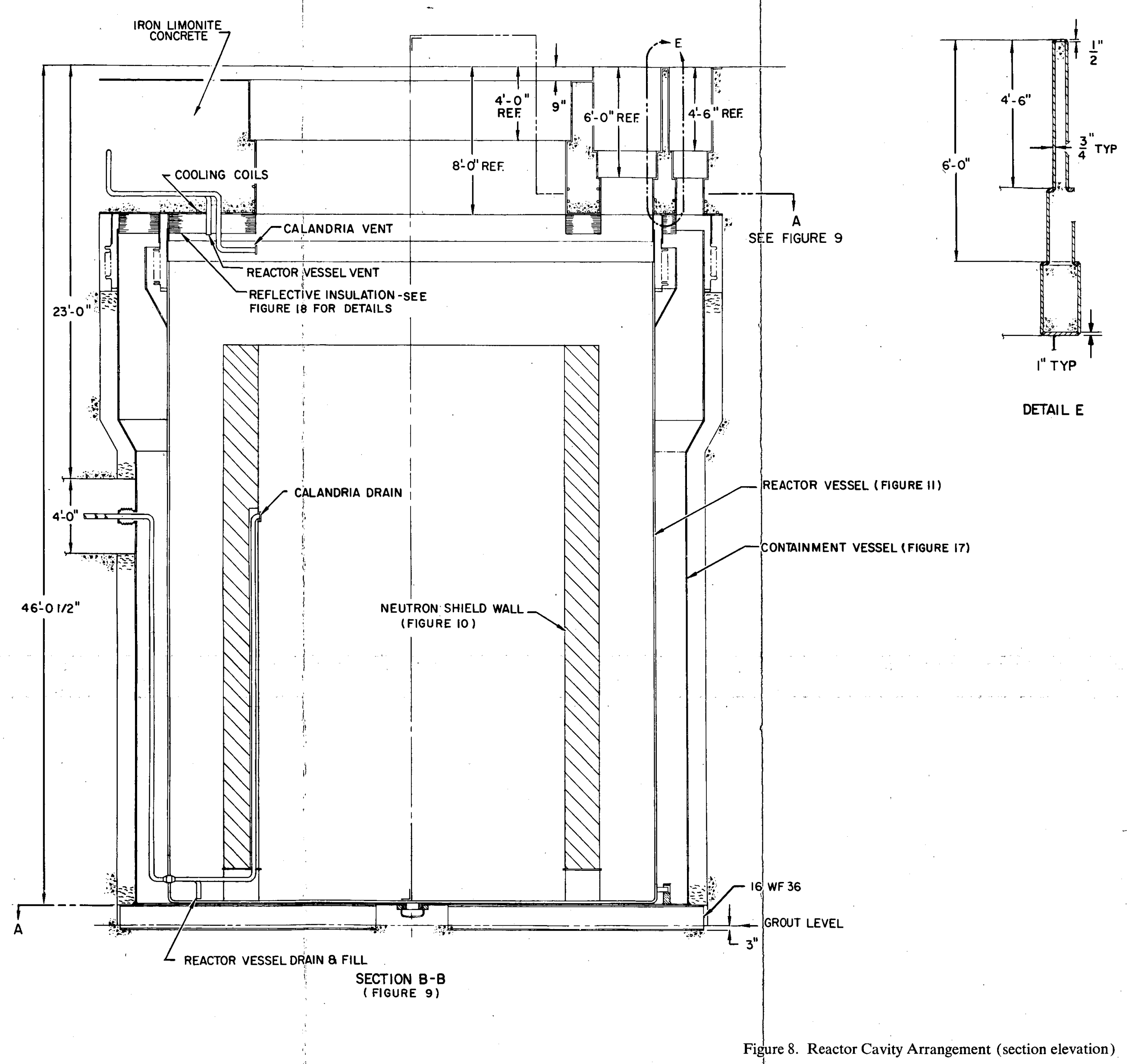




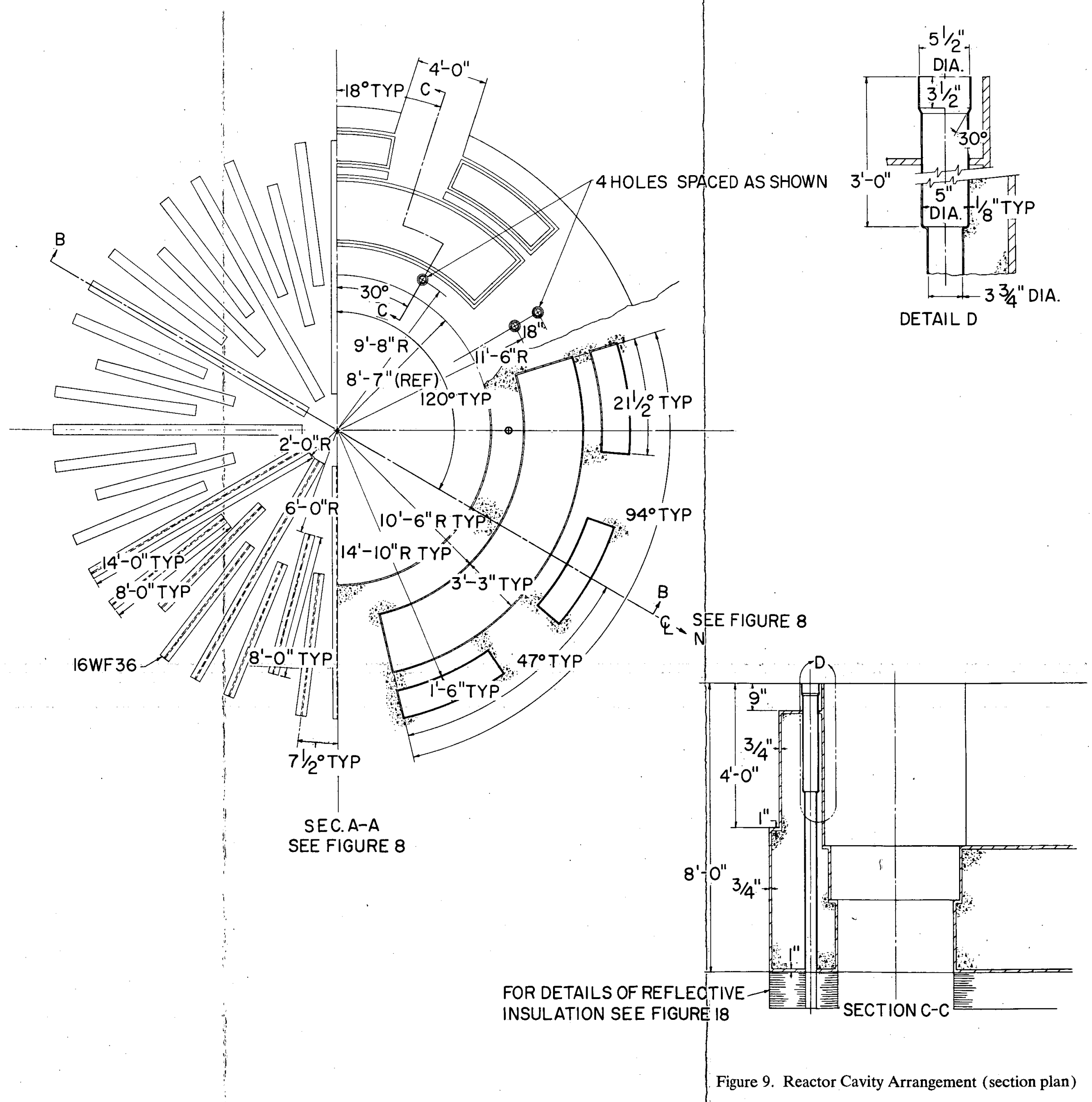




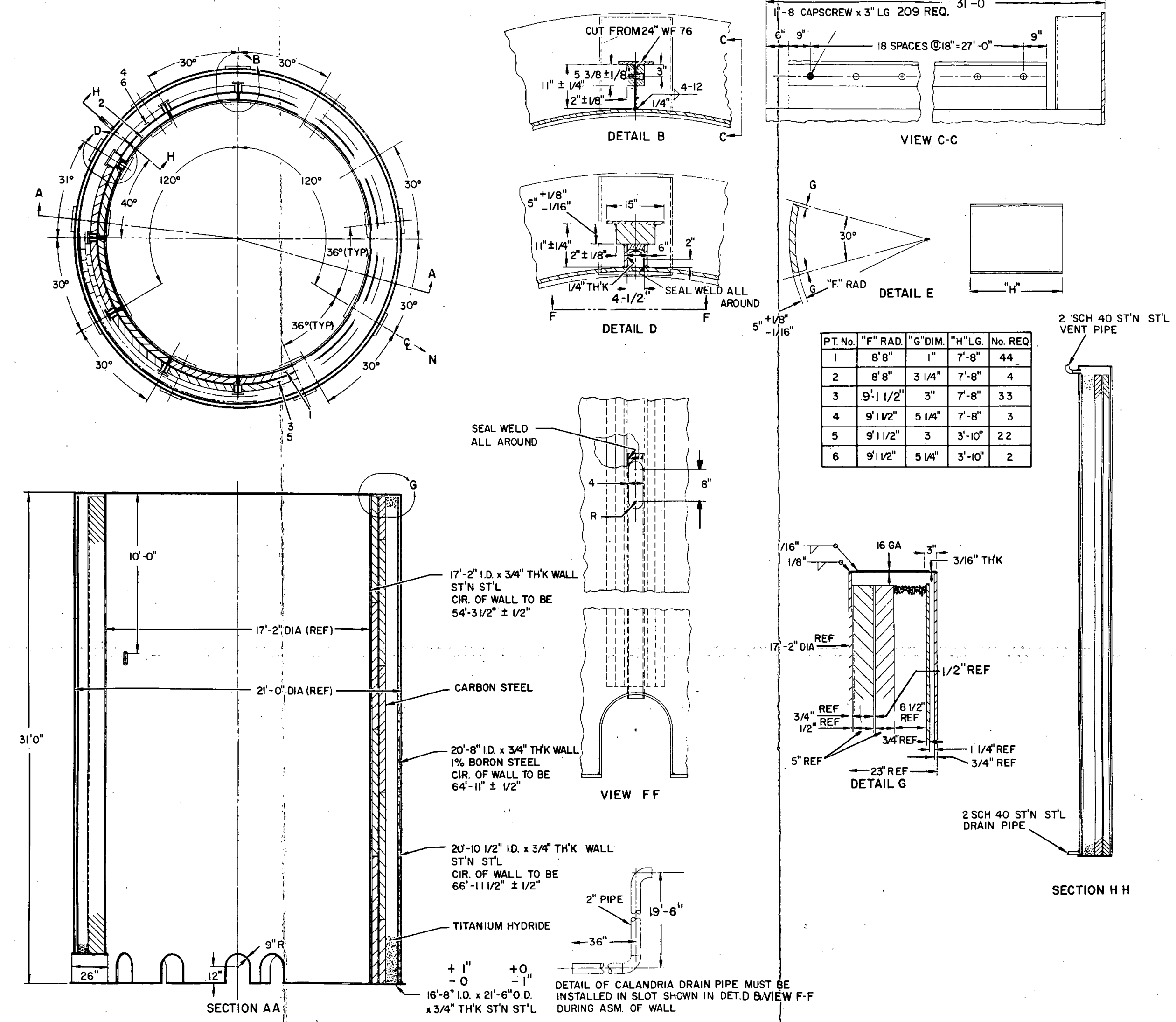

Figure 10. Neutron Shield Wall 


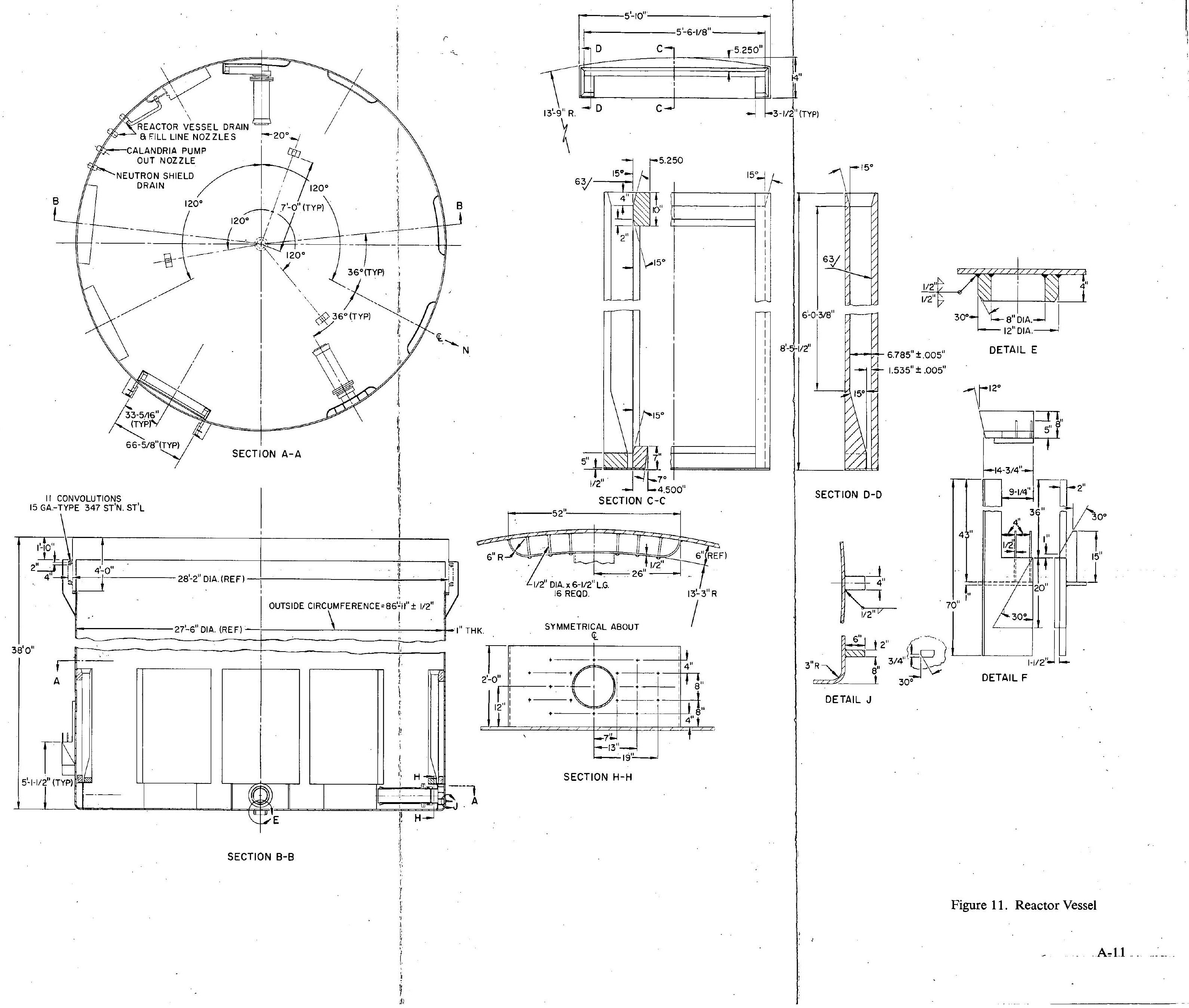




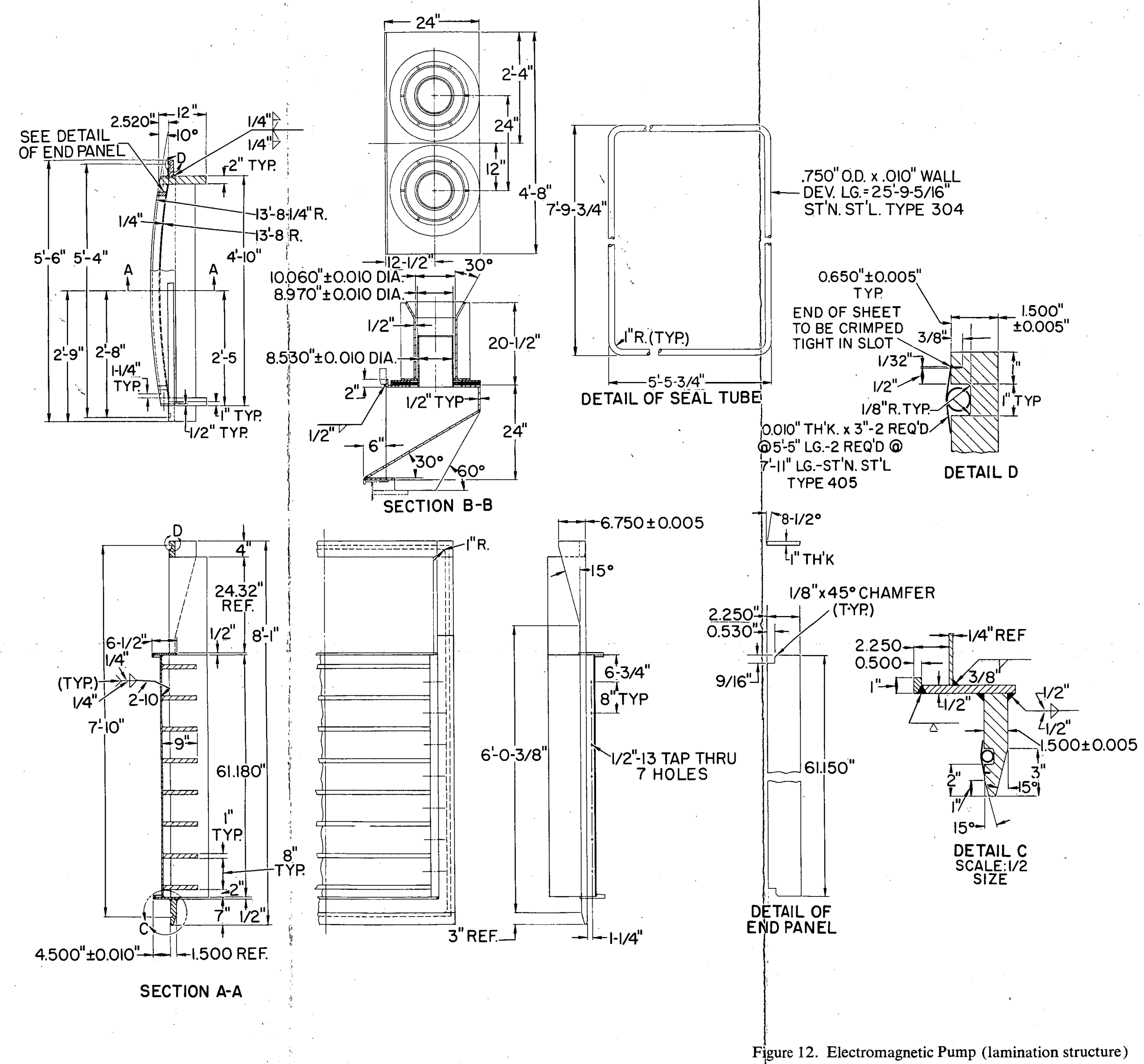




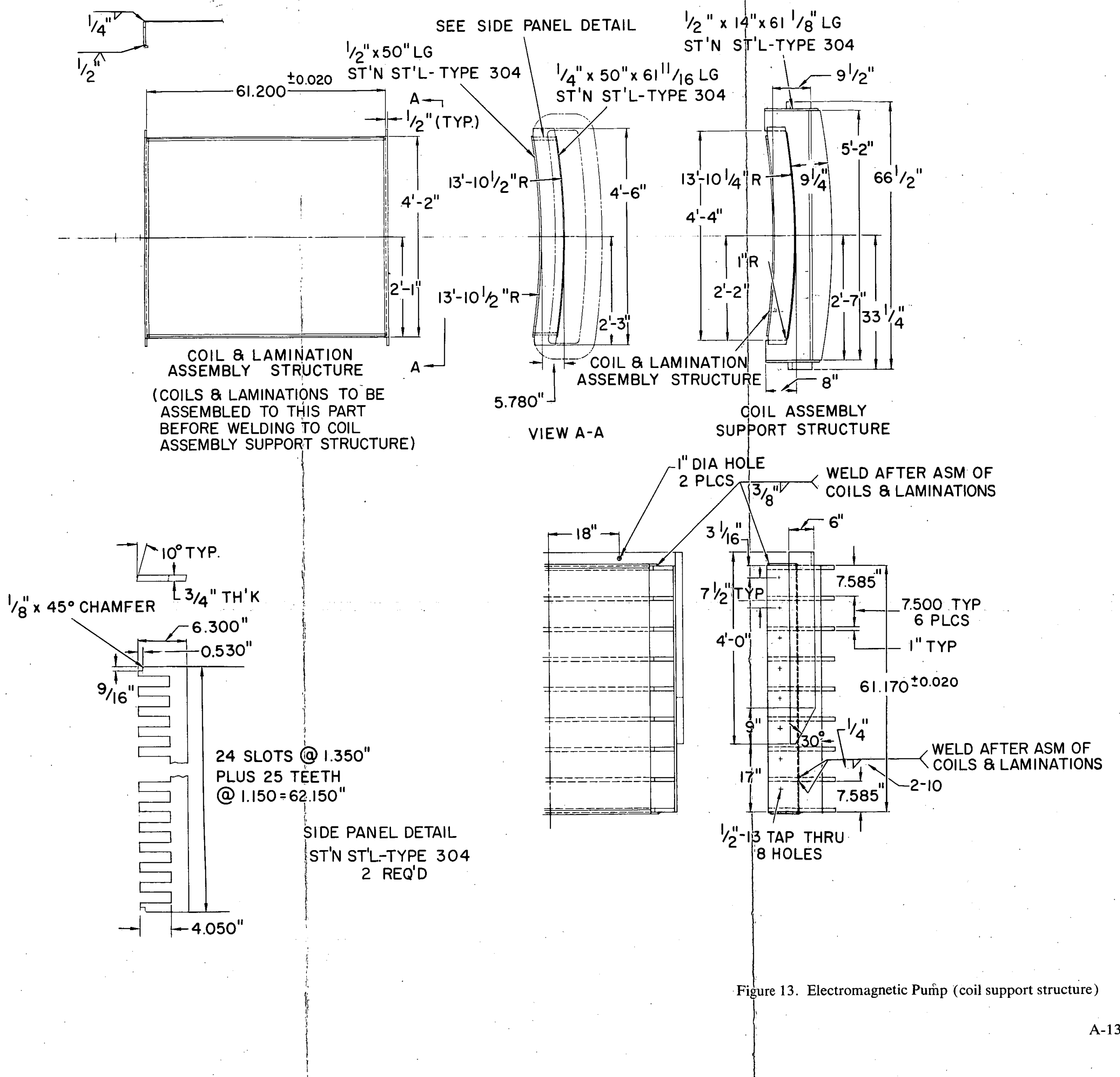




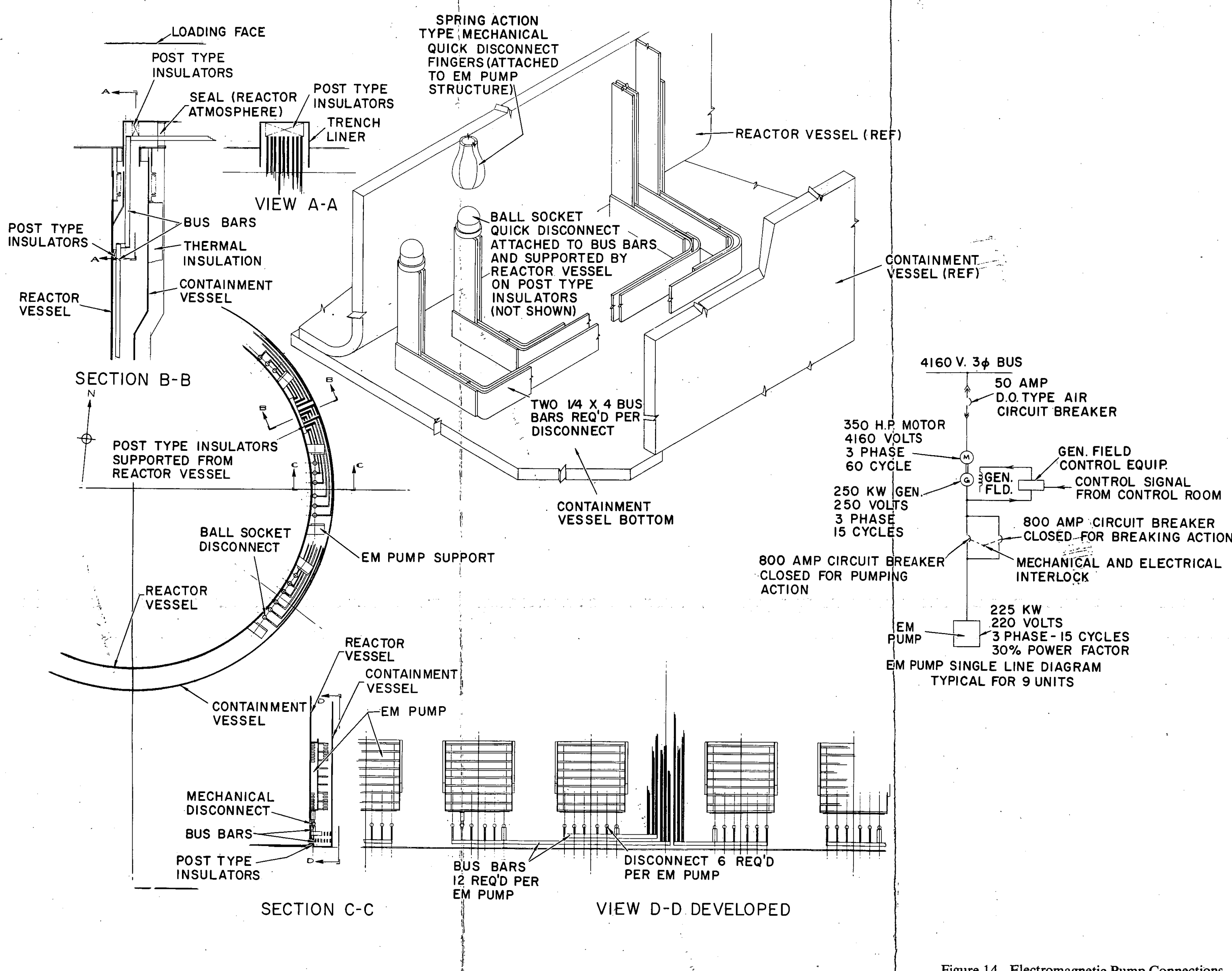




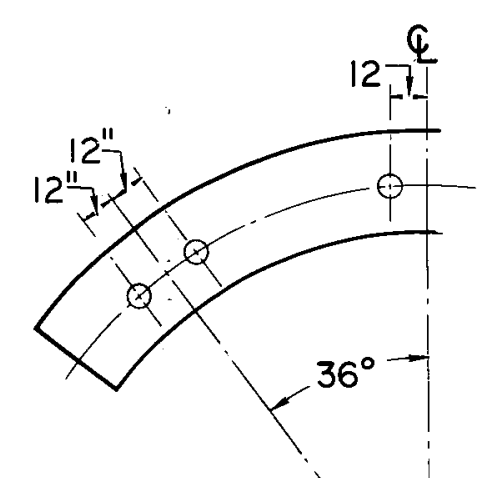

SECTION C-C
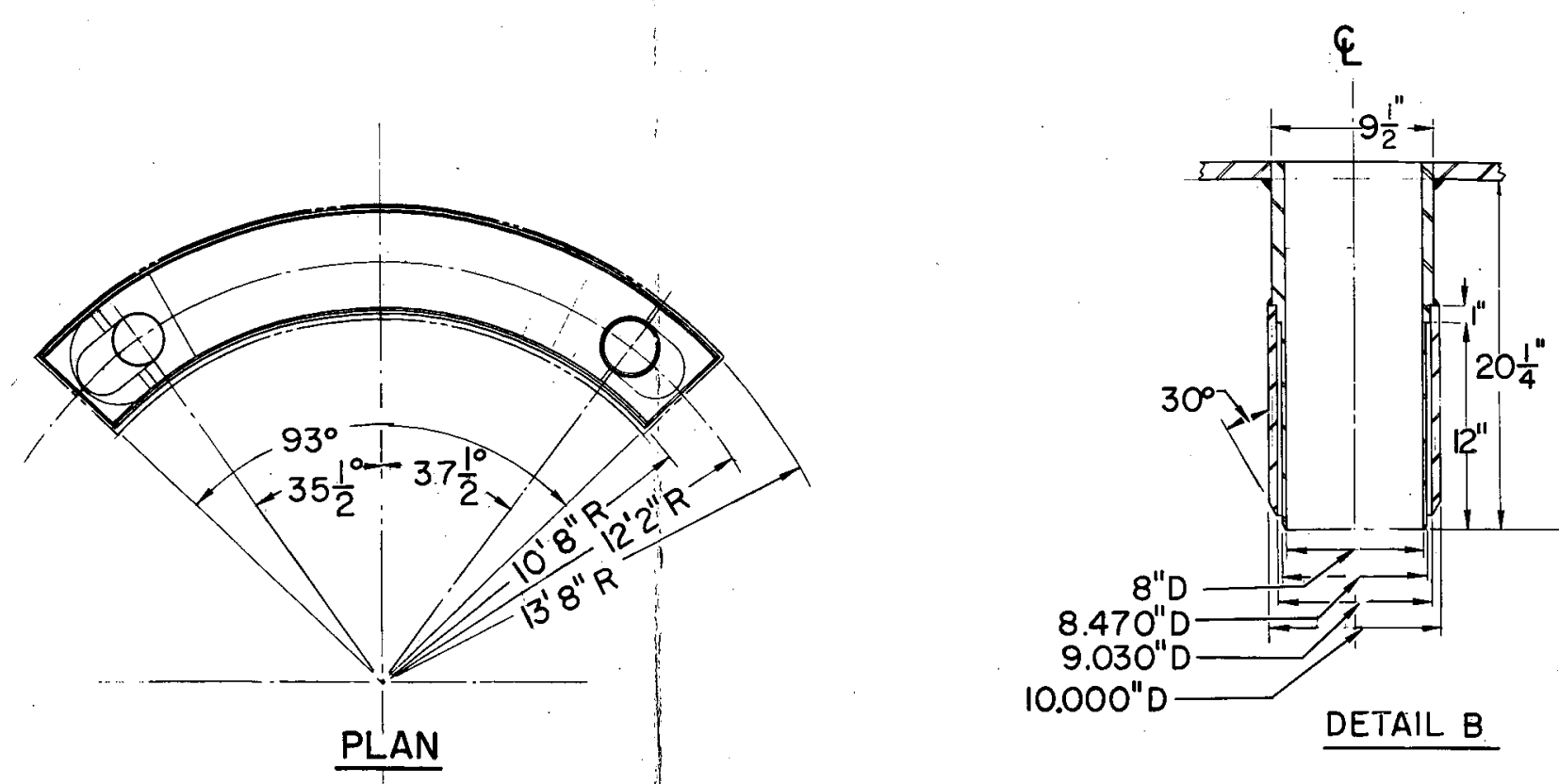

DESIGN DATA

FLOW RATE

Ib /HR (SHELL) (TUBES)

$\begin{array}{lll} & \\ & & \end{array}$

OUTLET TEMPERATURE OF $1200 \quad 600$

OPERATING PRESSURE PSIG

OF $1275-1275$

DESIGN PRESSURE

PSIG $\quad 7 \quad 100$

MAX PRESSURE DROP PSI 5

PRIMARY SODIUM INLETS

PRIMARY SODIUM INLETS

ENTIAL PRESSURE AT DESIGN

FLOW \& TEMPERATURE)

\begin{tabular}{|l} 
SECONDARY A- \\
SECONDARY \\
SODIUM INLET
\end{tabular} PLAN

$10.000^{\prime \prime} \mathrm{D}$

DETAIL B

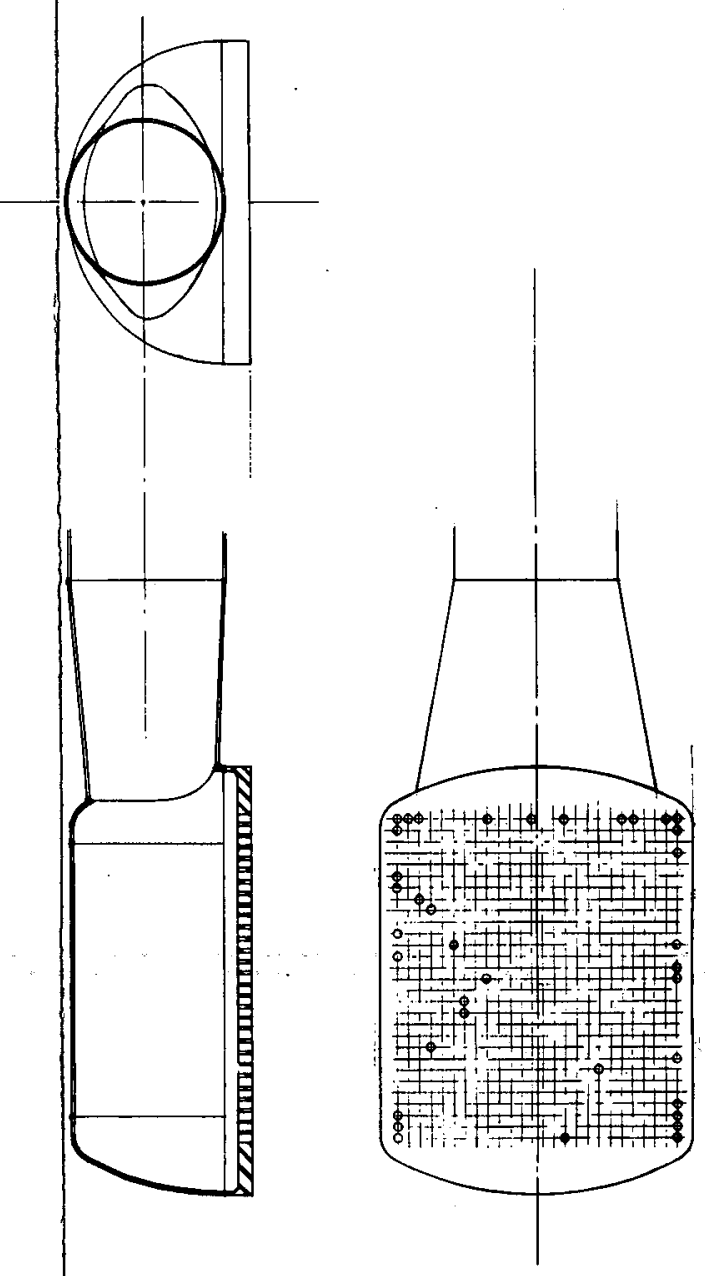

HEADER DETAIL

Figure 15. Intermediate Heat Exchanger 


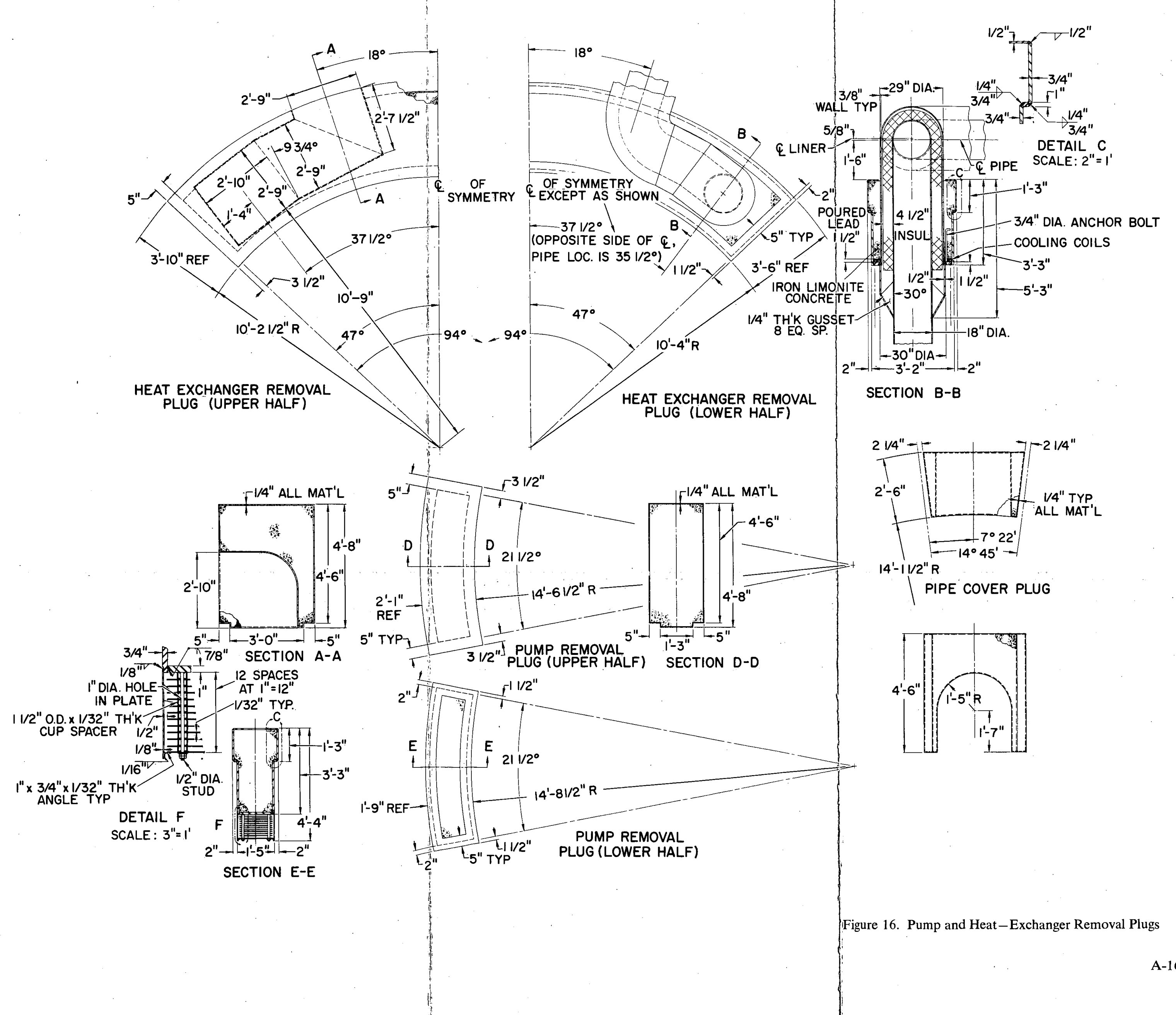




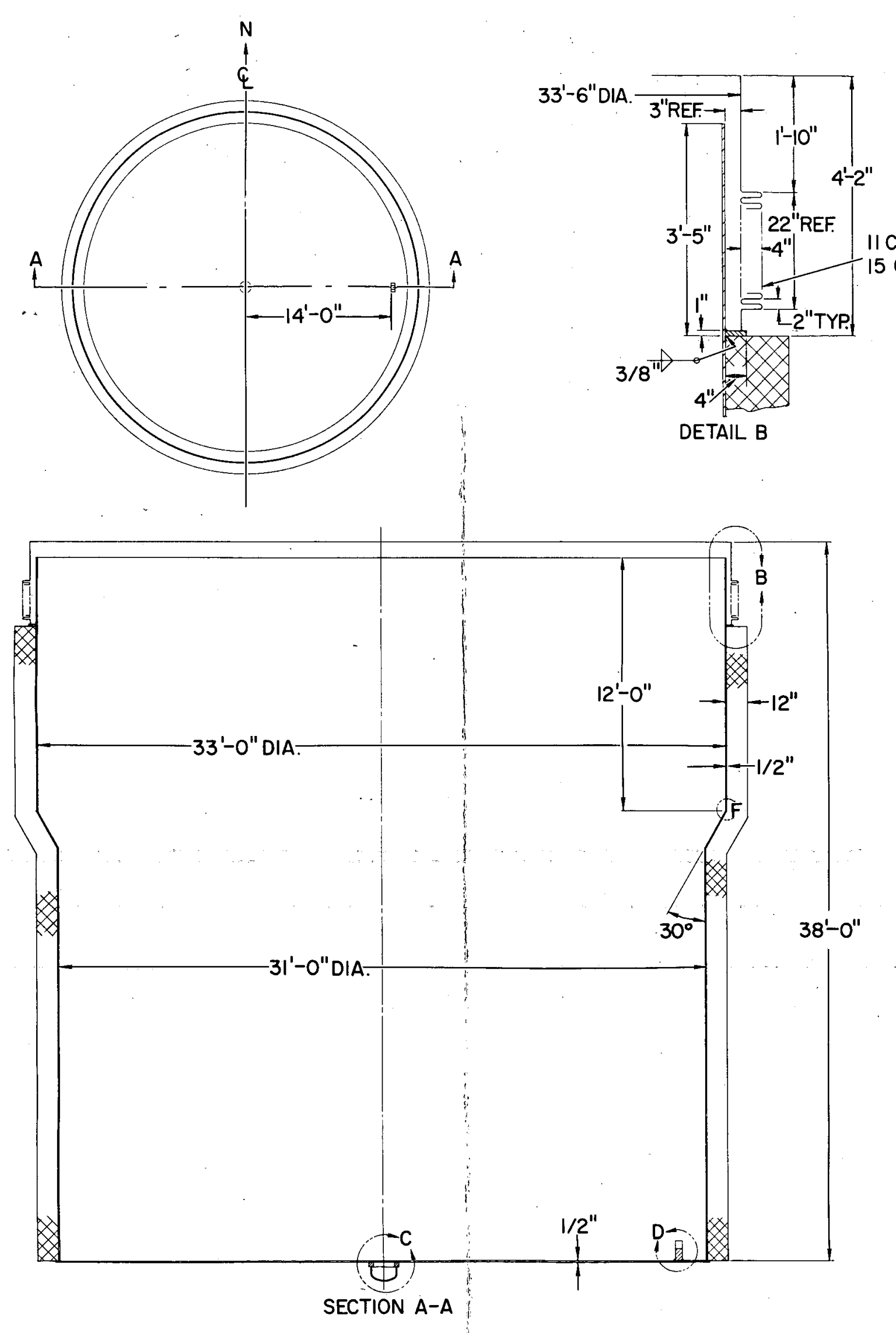

II CONVOLUTIONS
G GA.-TYPE 347 ST'N ST'L.
DETAIL F
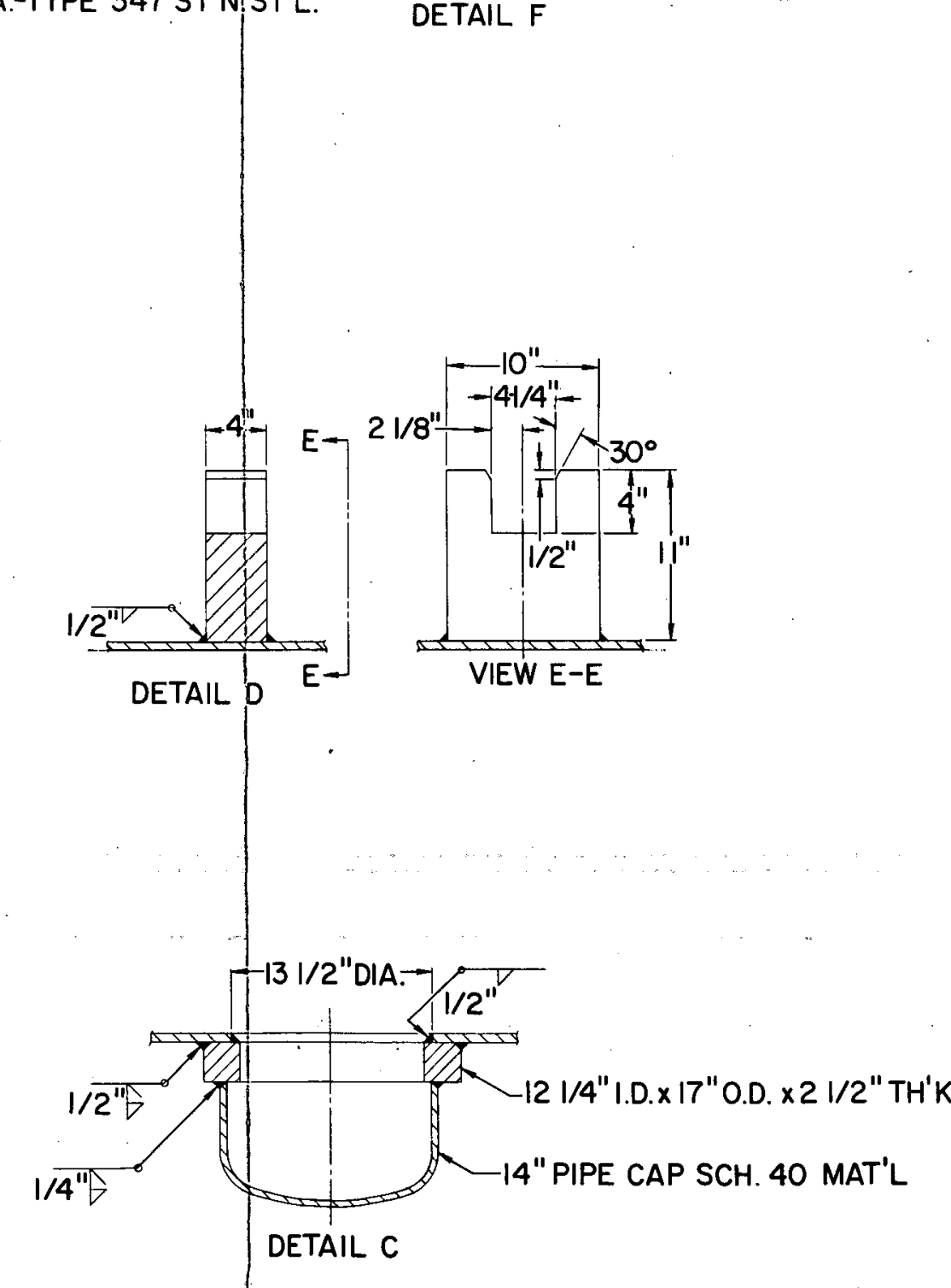

Figure 17. Containment Vessel 

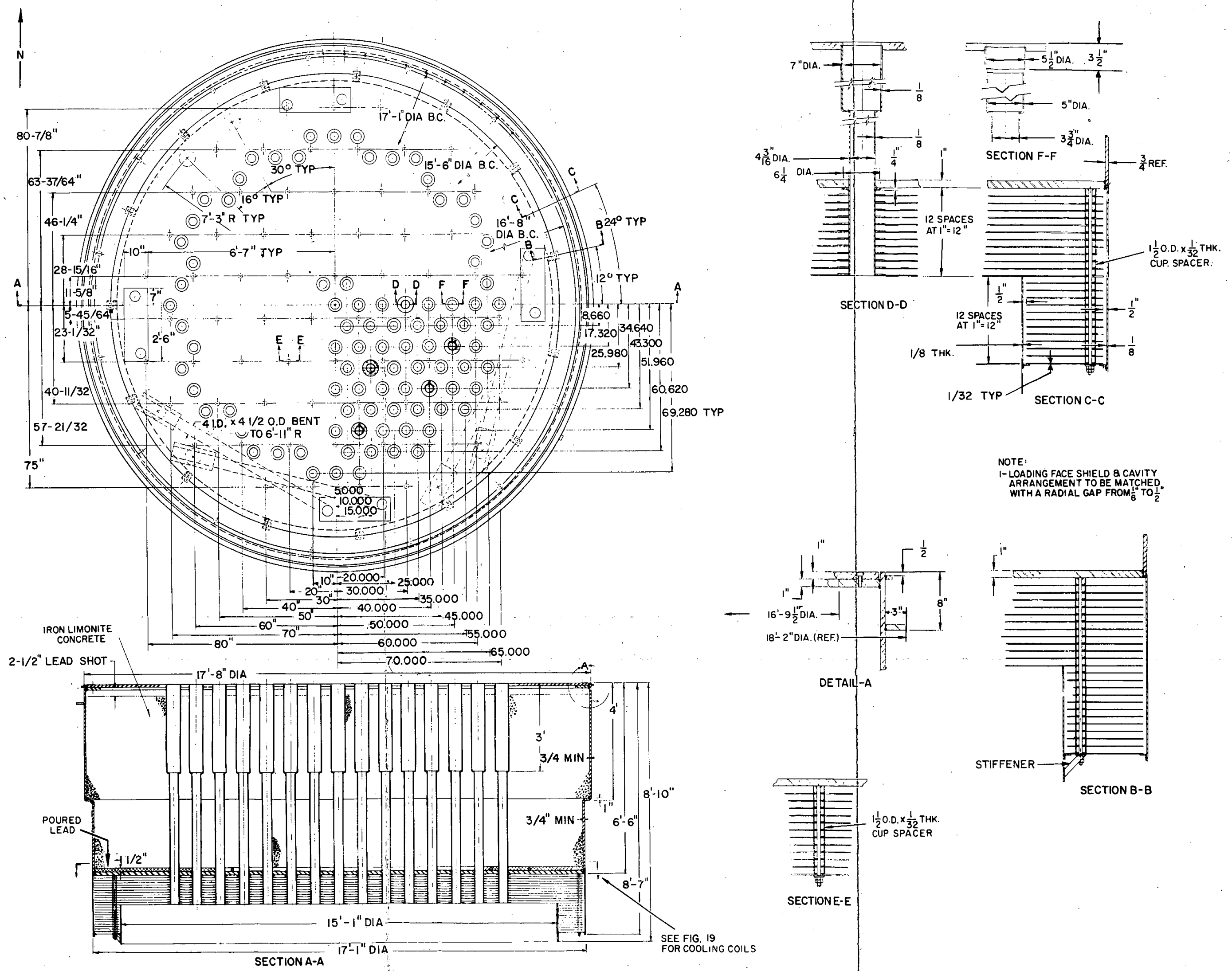

more:

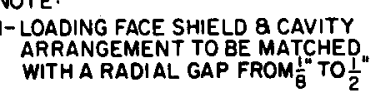
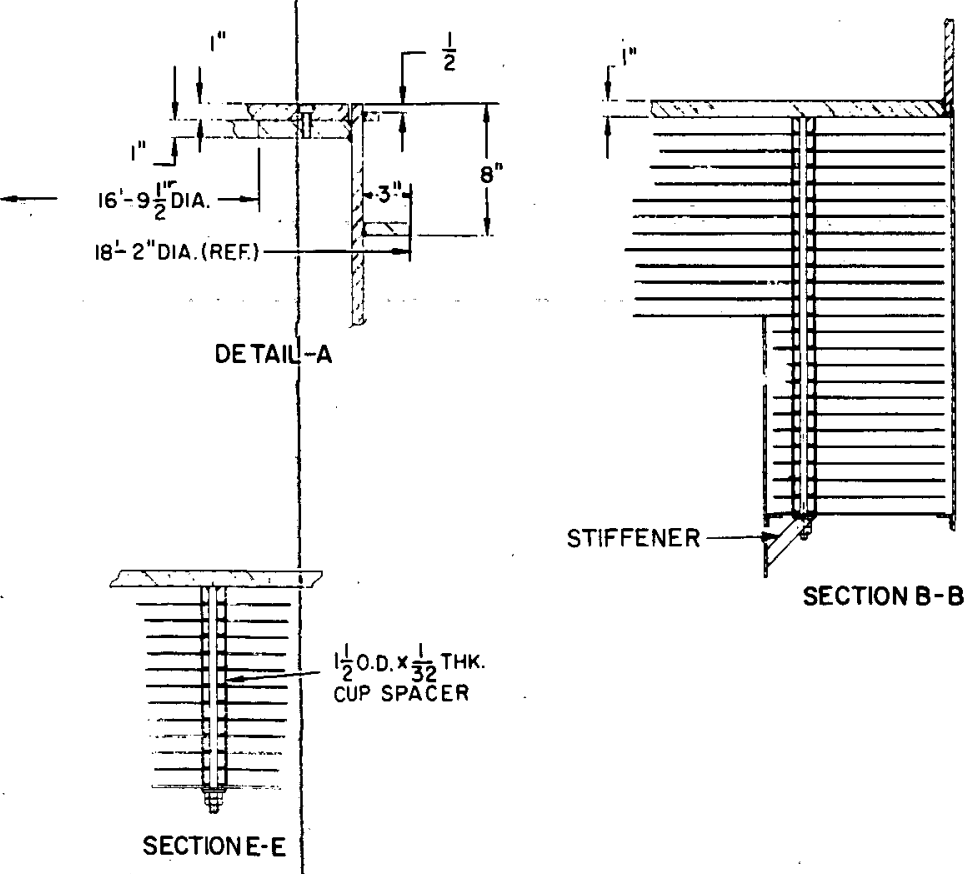

SECTION B-B

Figure 18. Loading-Face Shield 


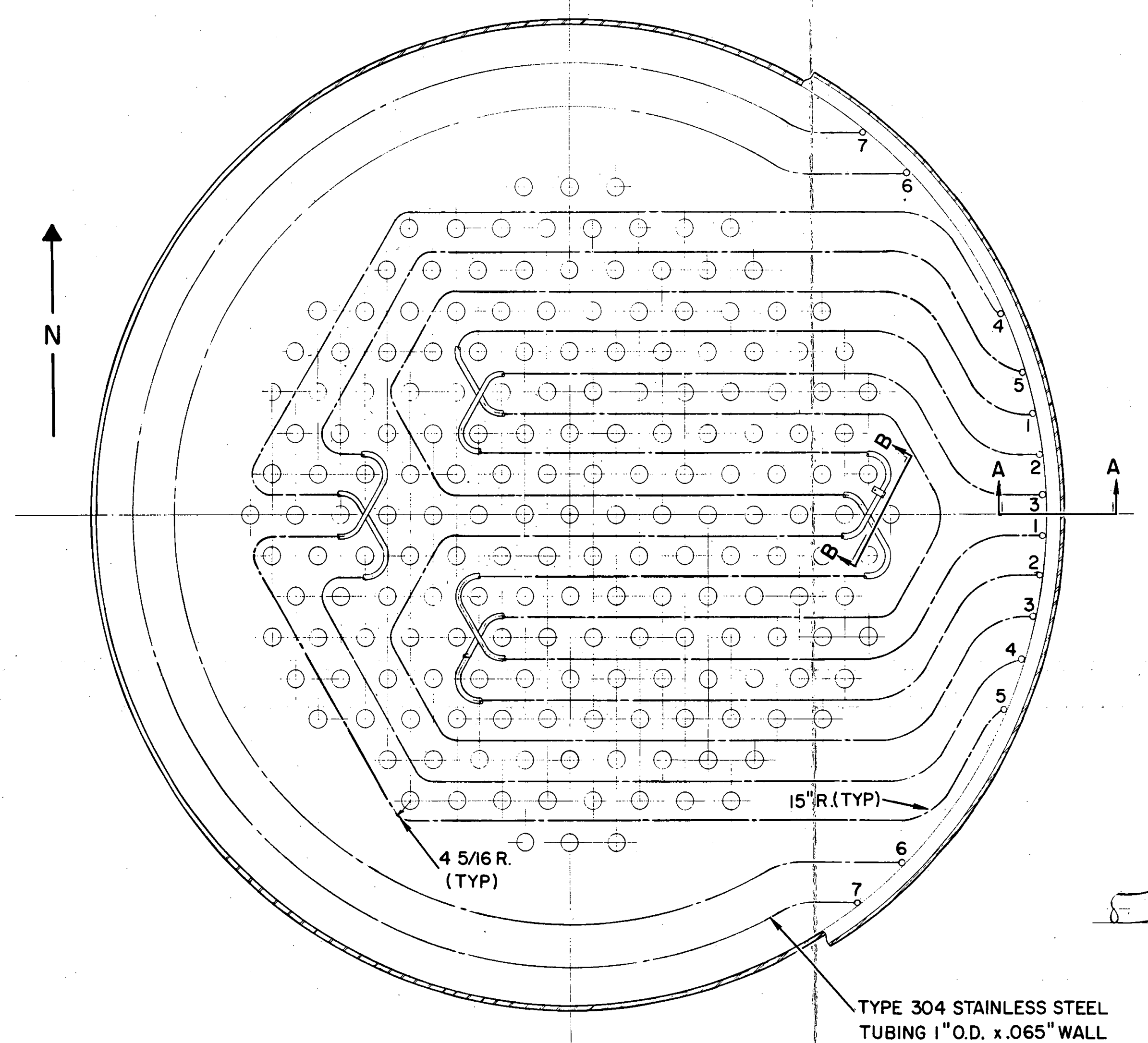

BULKHEAD UNION

(FLARED TUBE FITTING)

TUBING I" O.D. X.065" WALL

Figure 19. Cooling Coils (loading-face shield) 


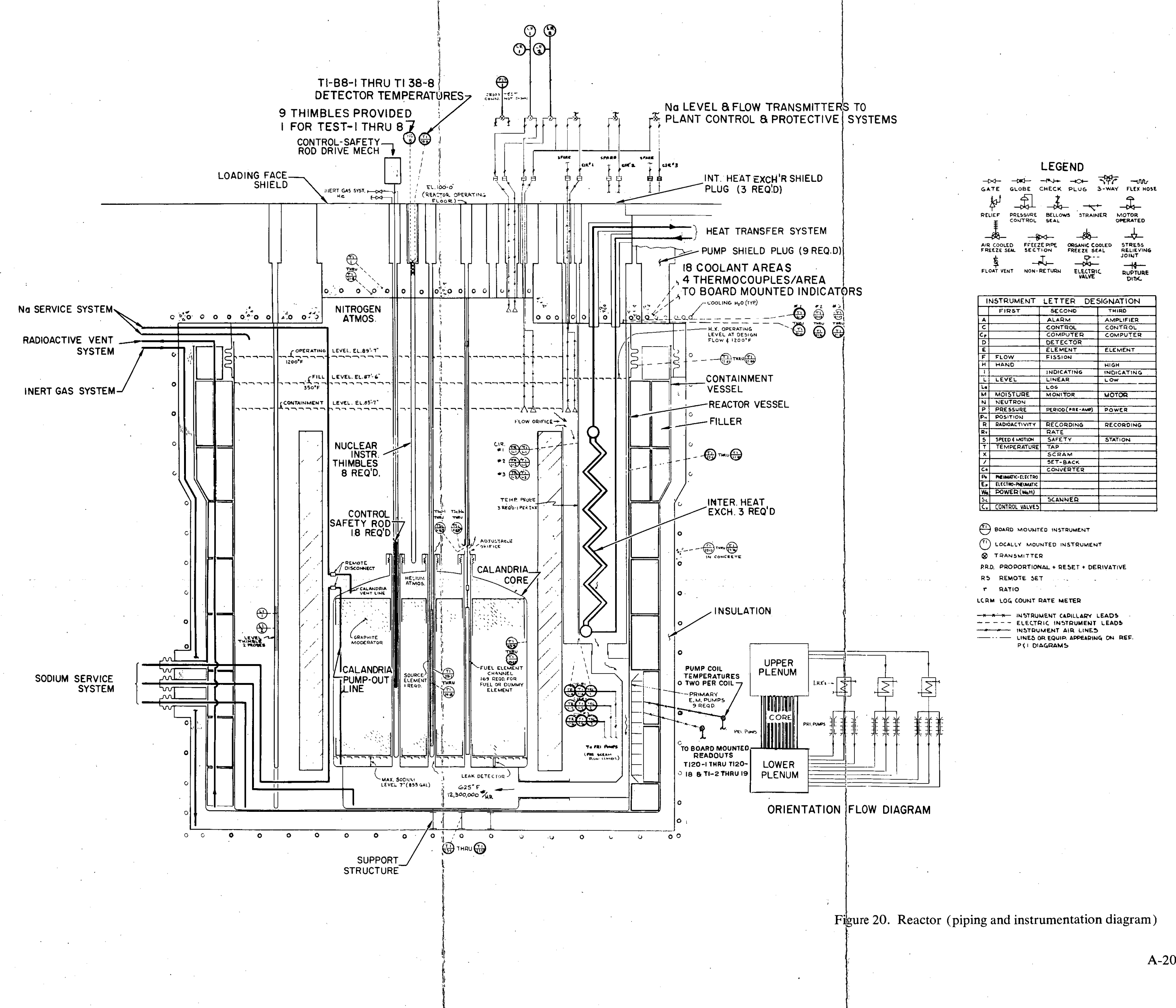




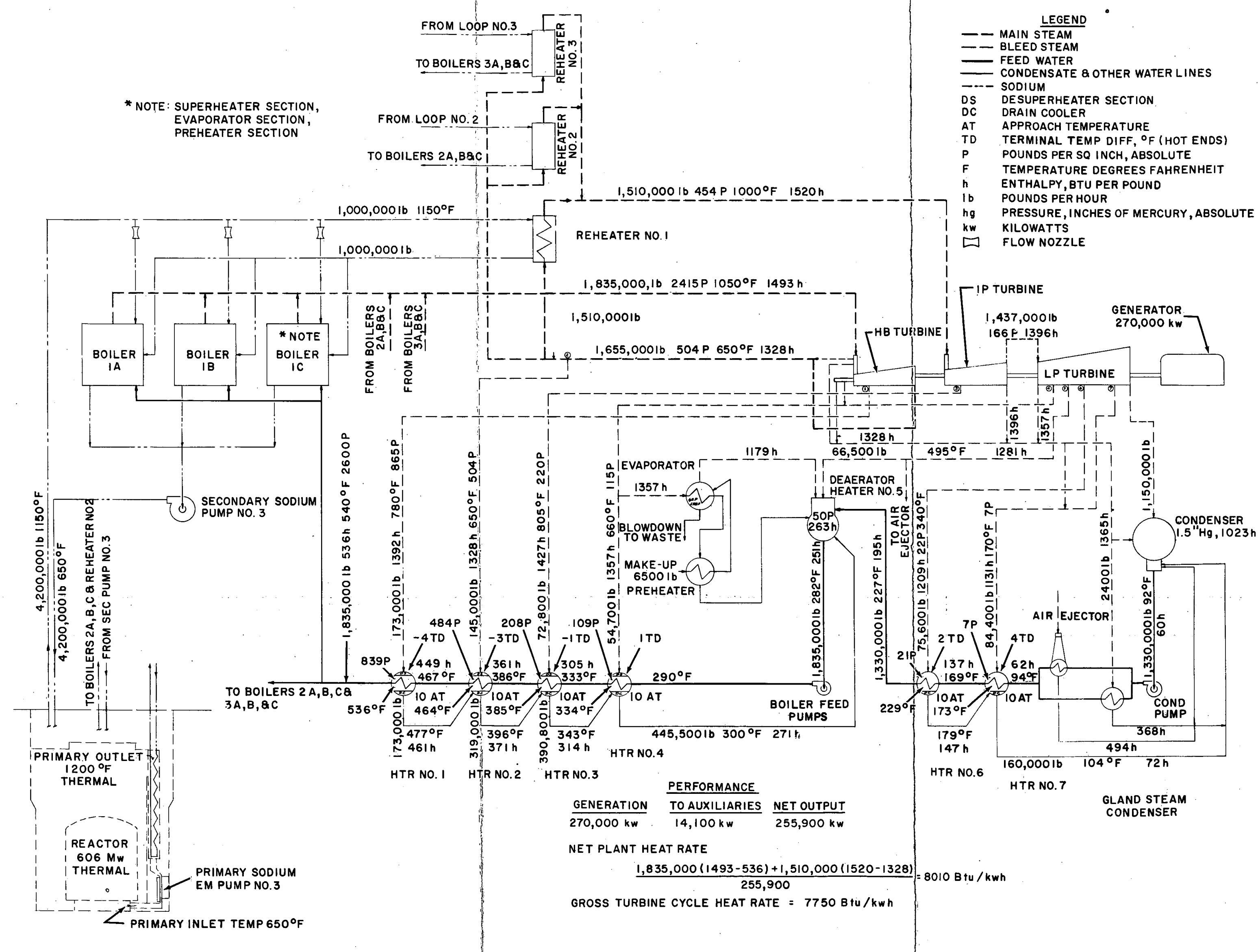




\section{a}

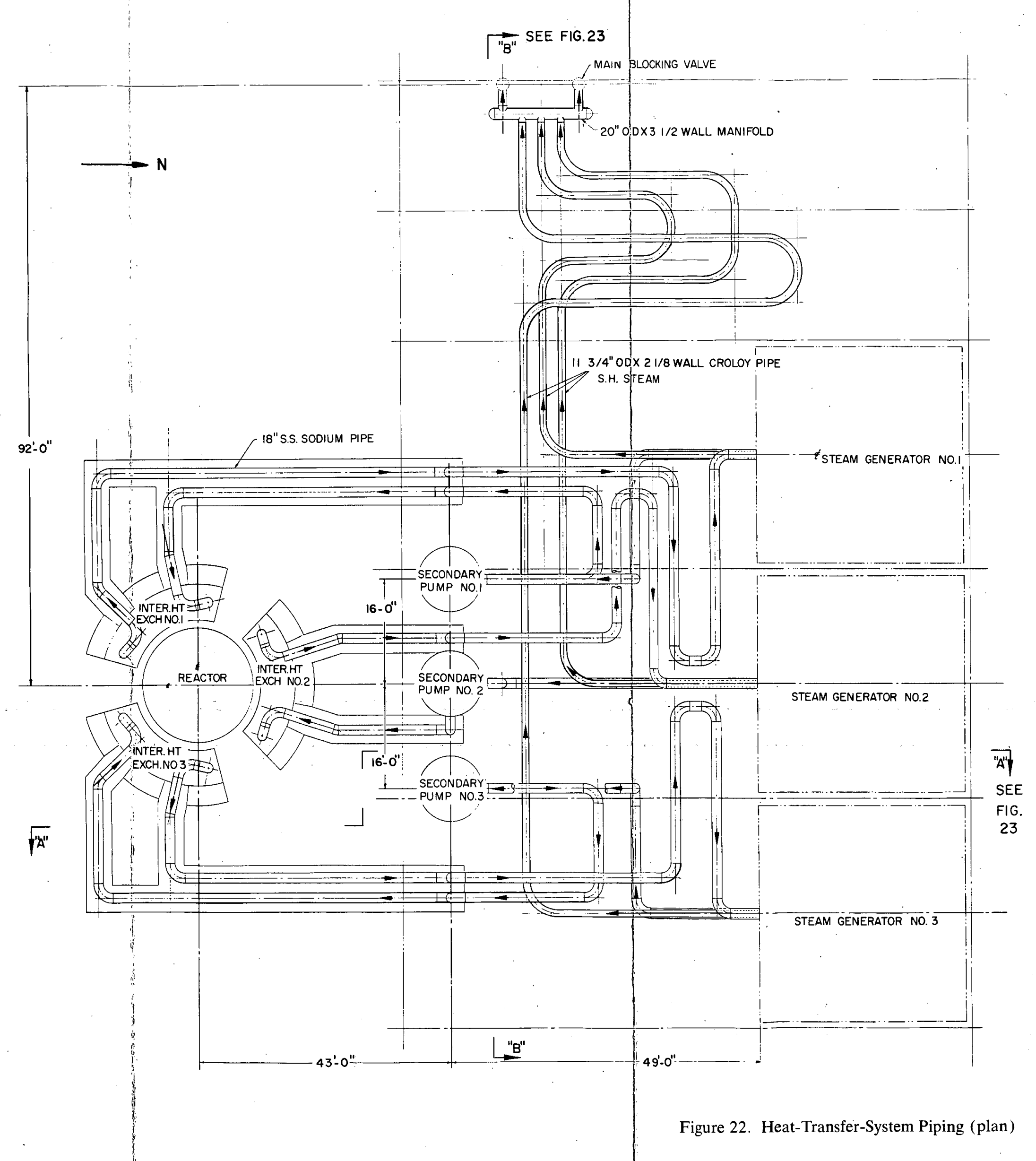




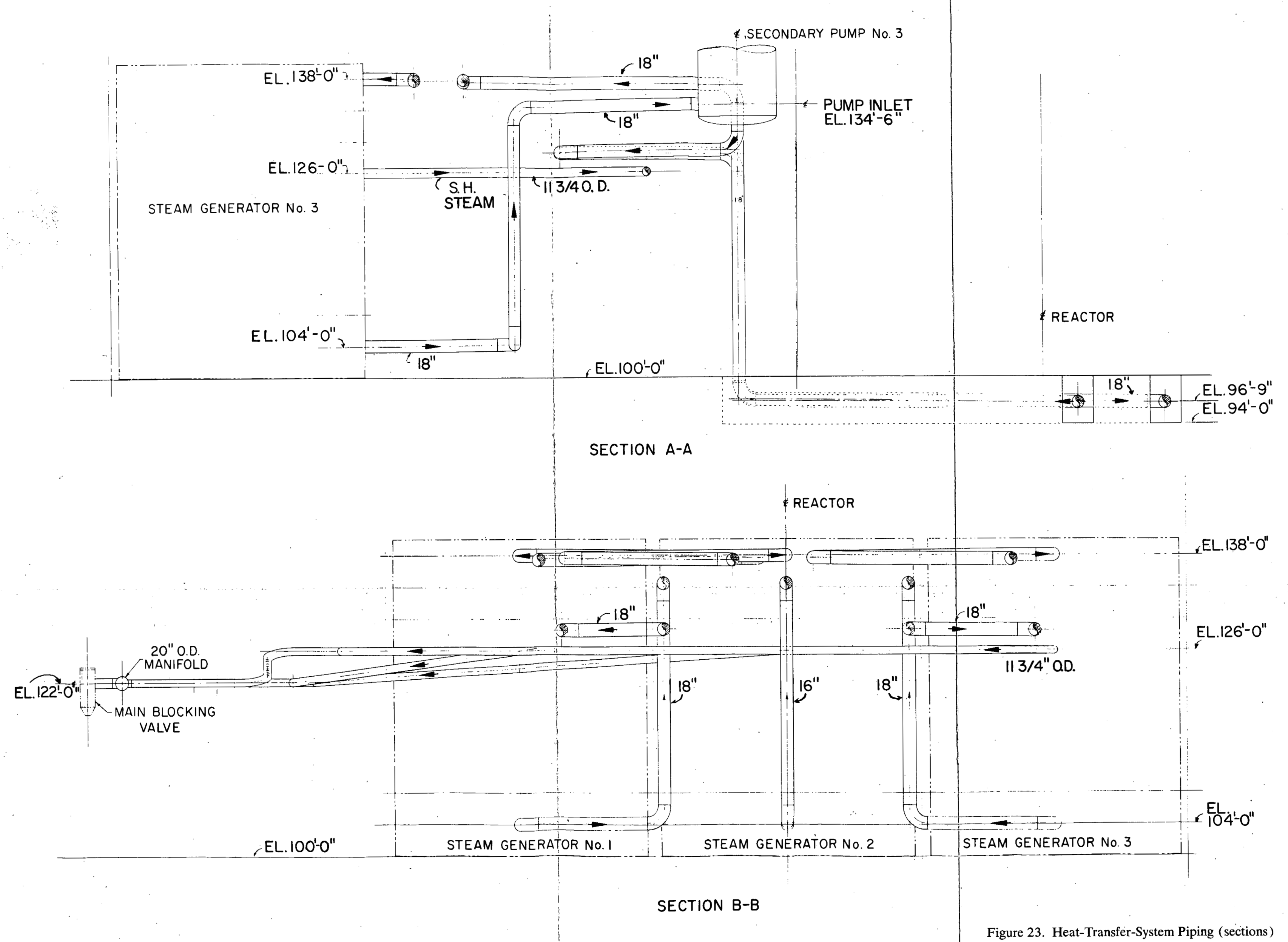




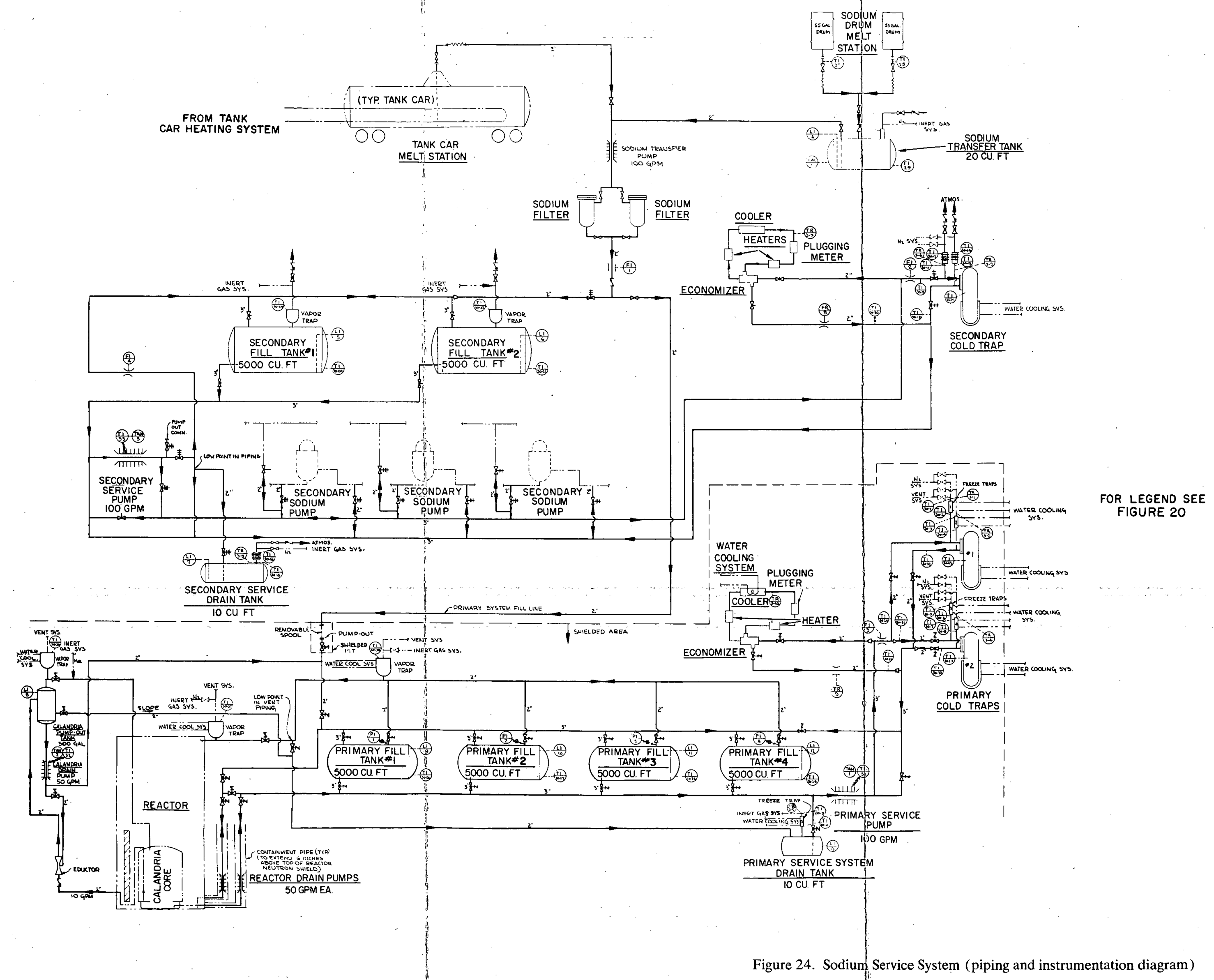



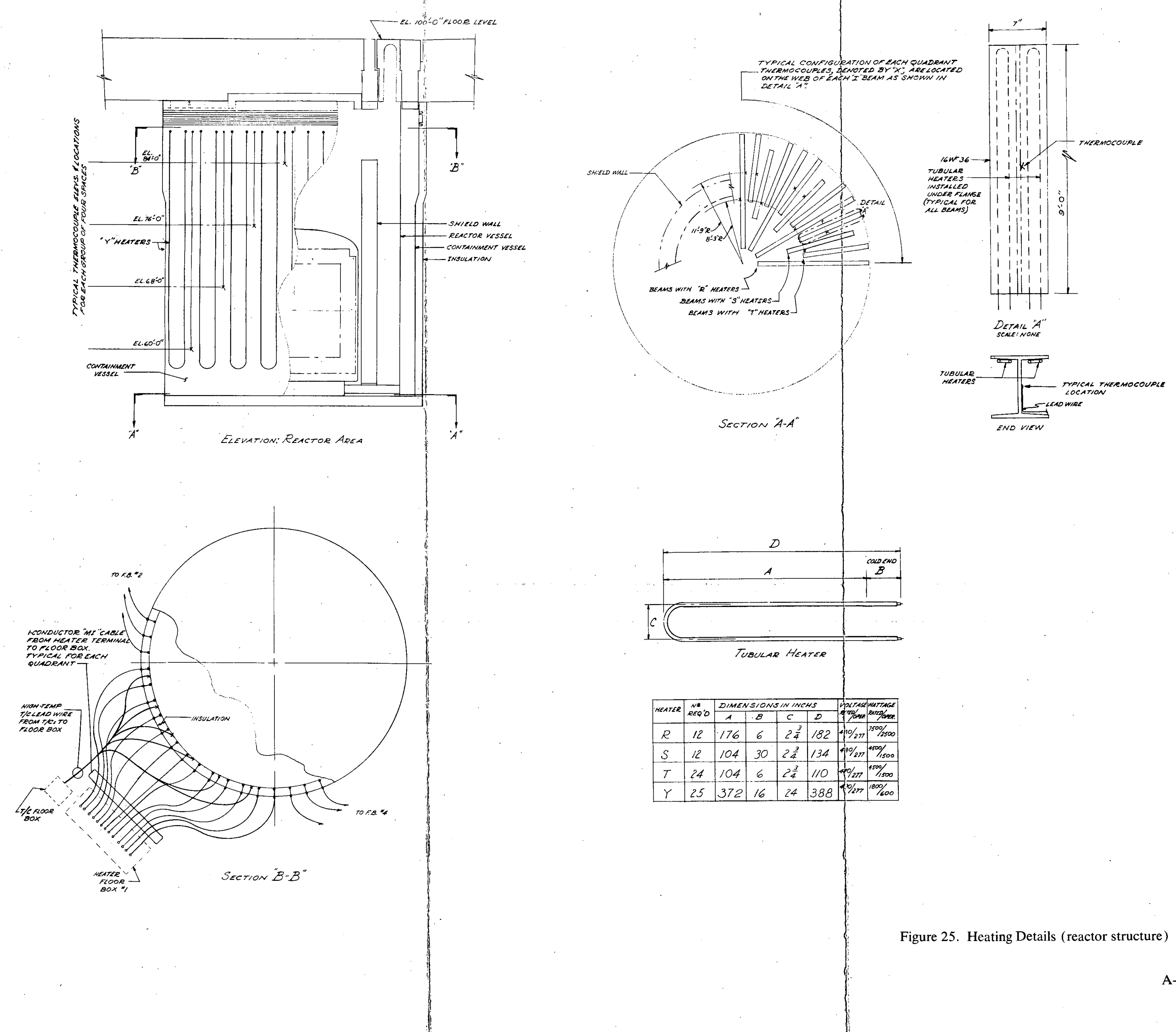

Figure 25. Heating Details (reactor structure) 


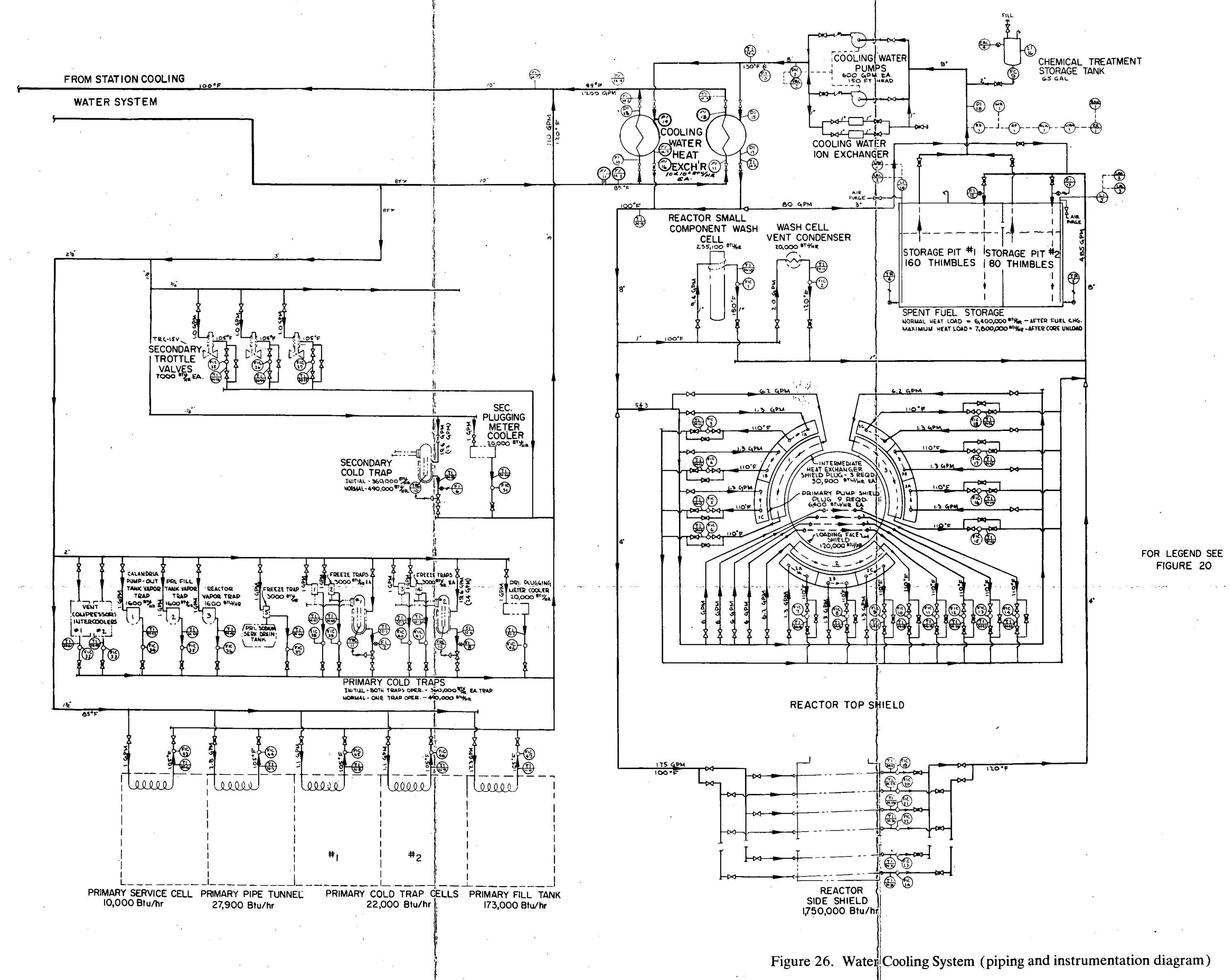




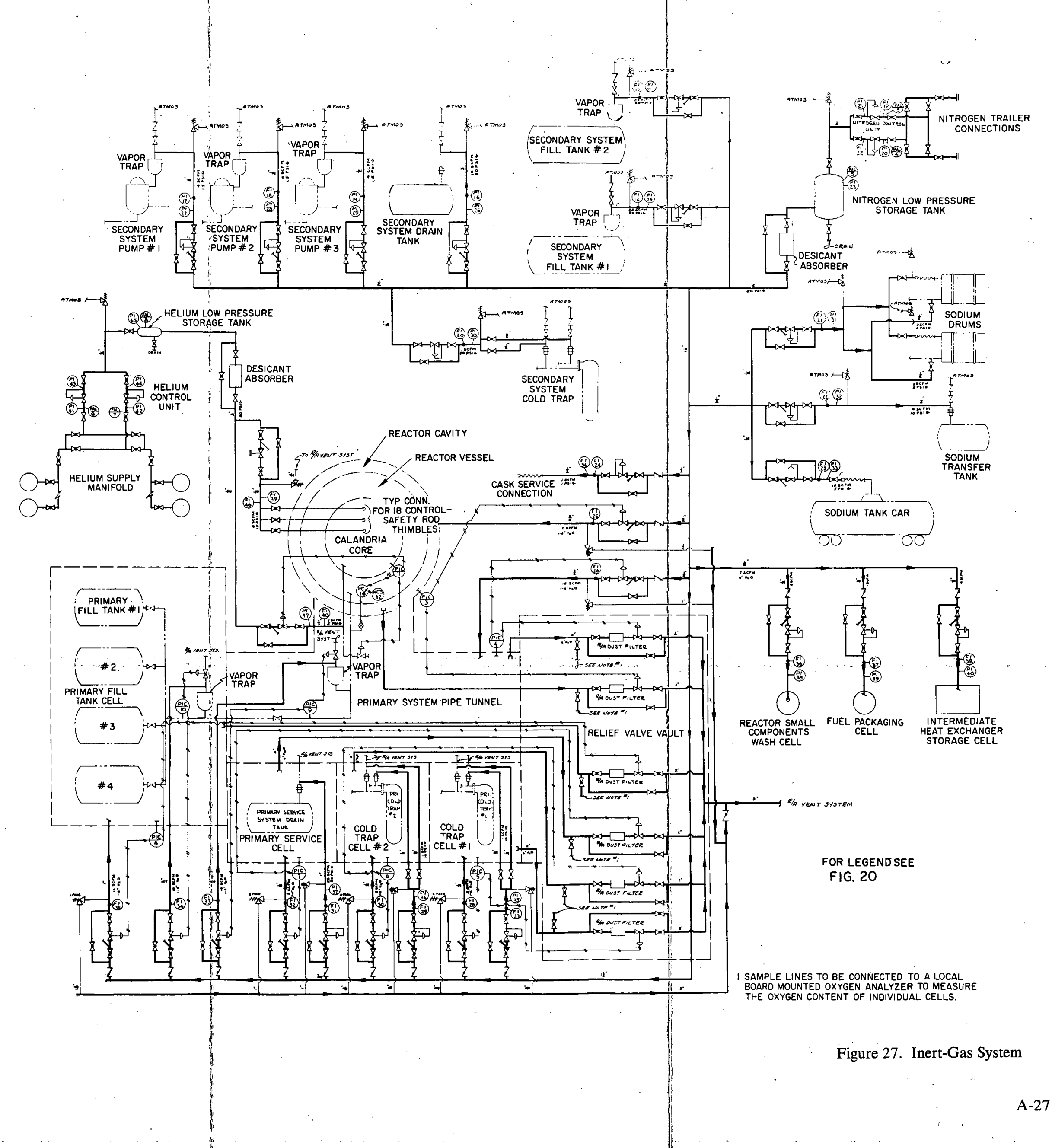




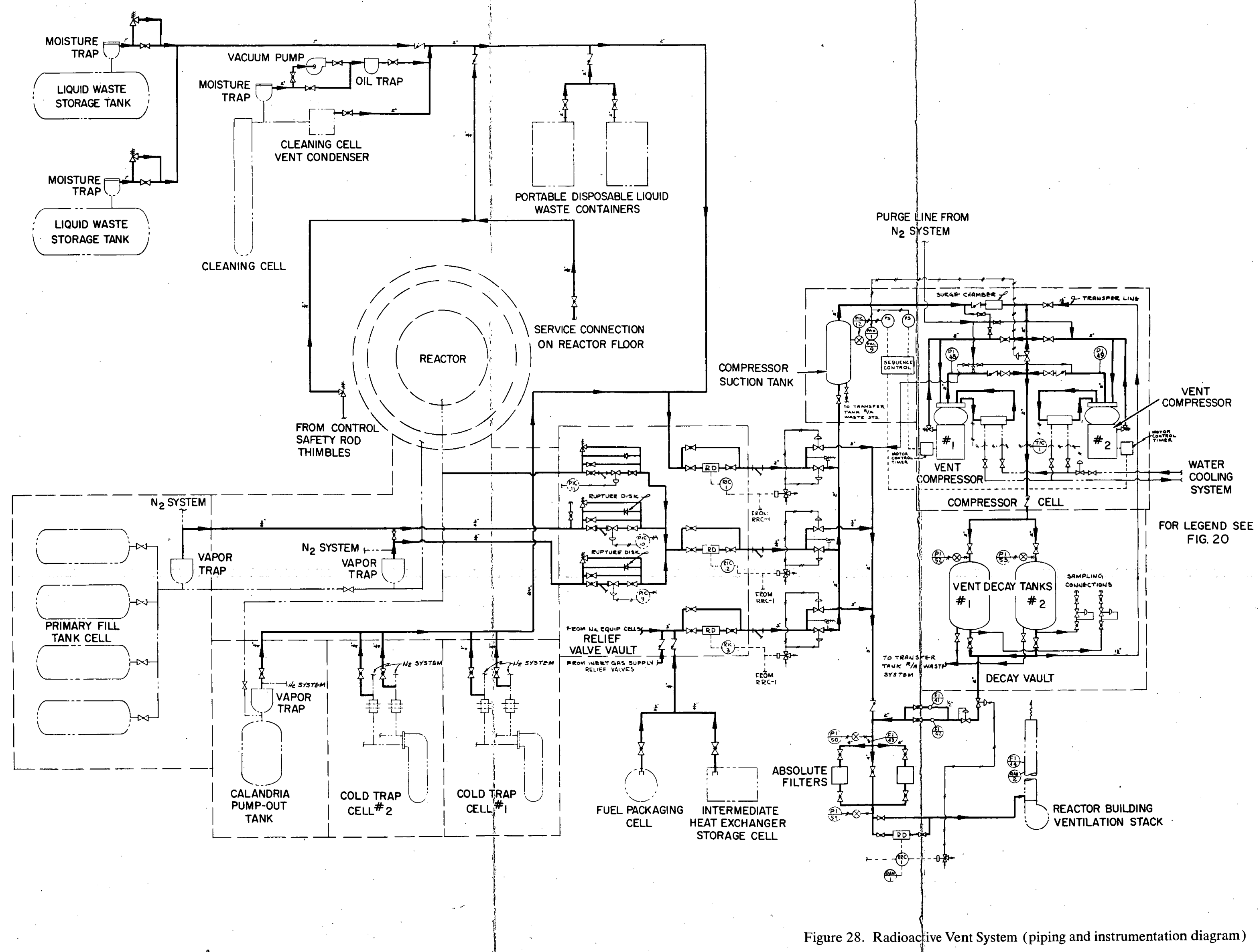


0

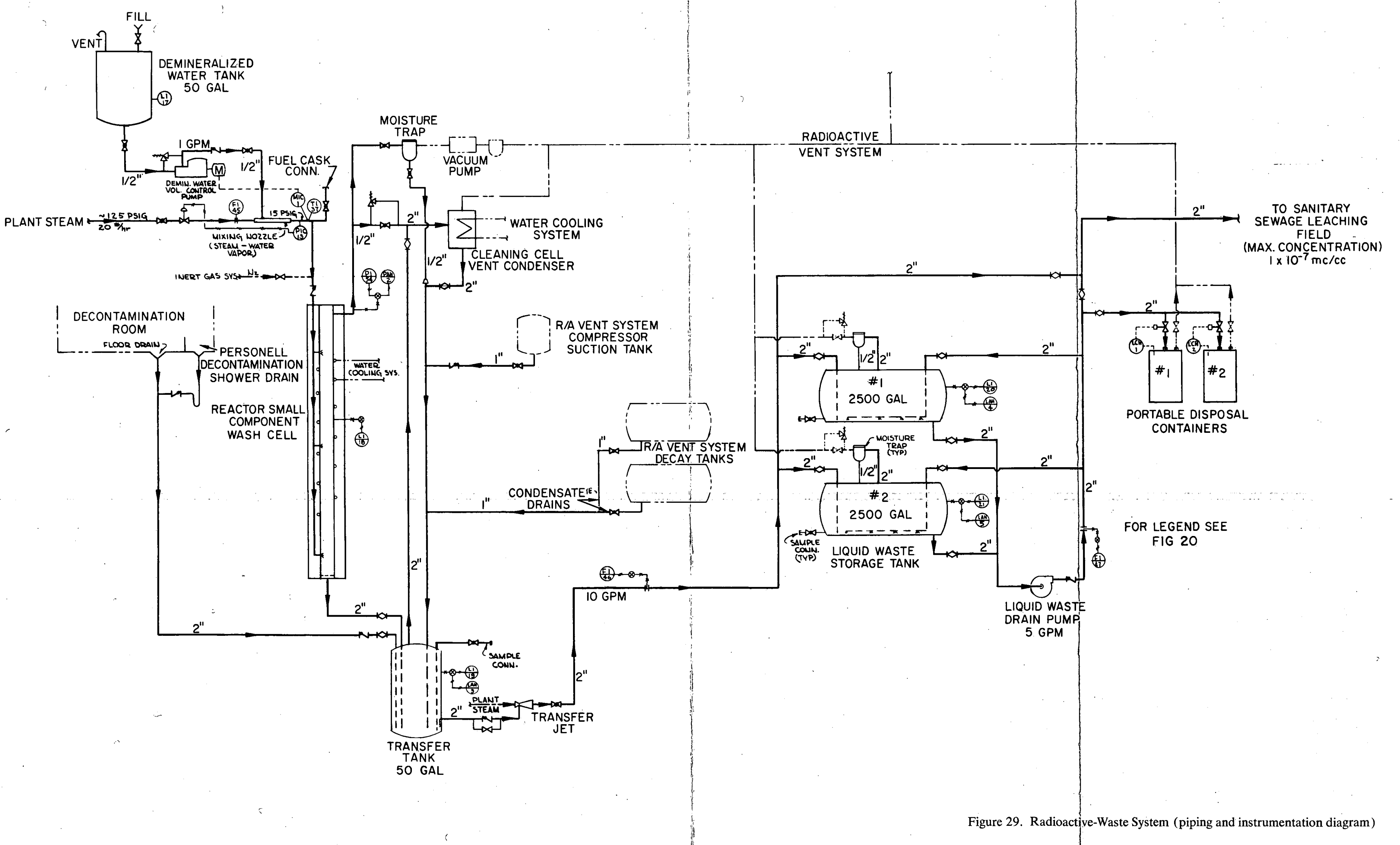


0
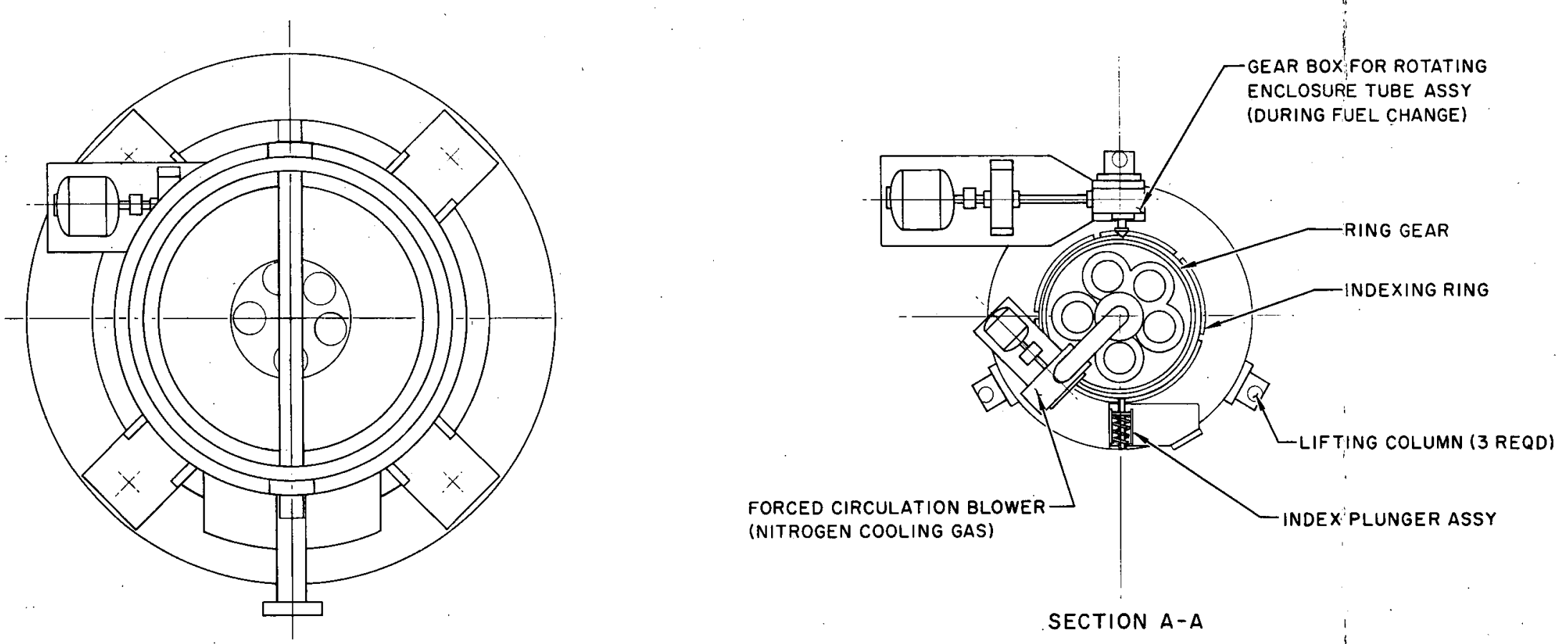

SECTION A-A
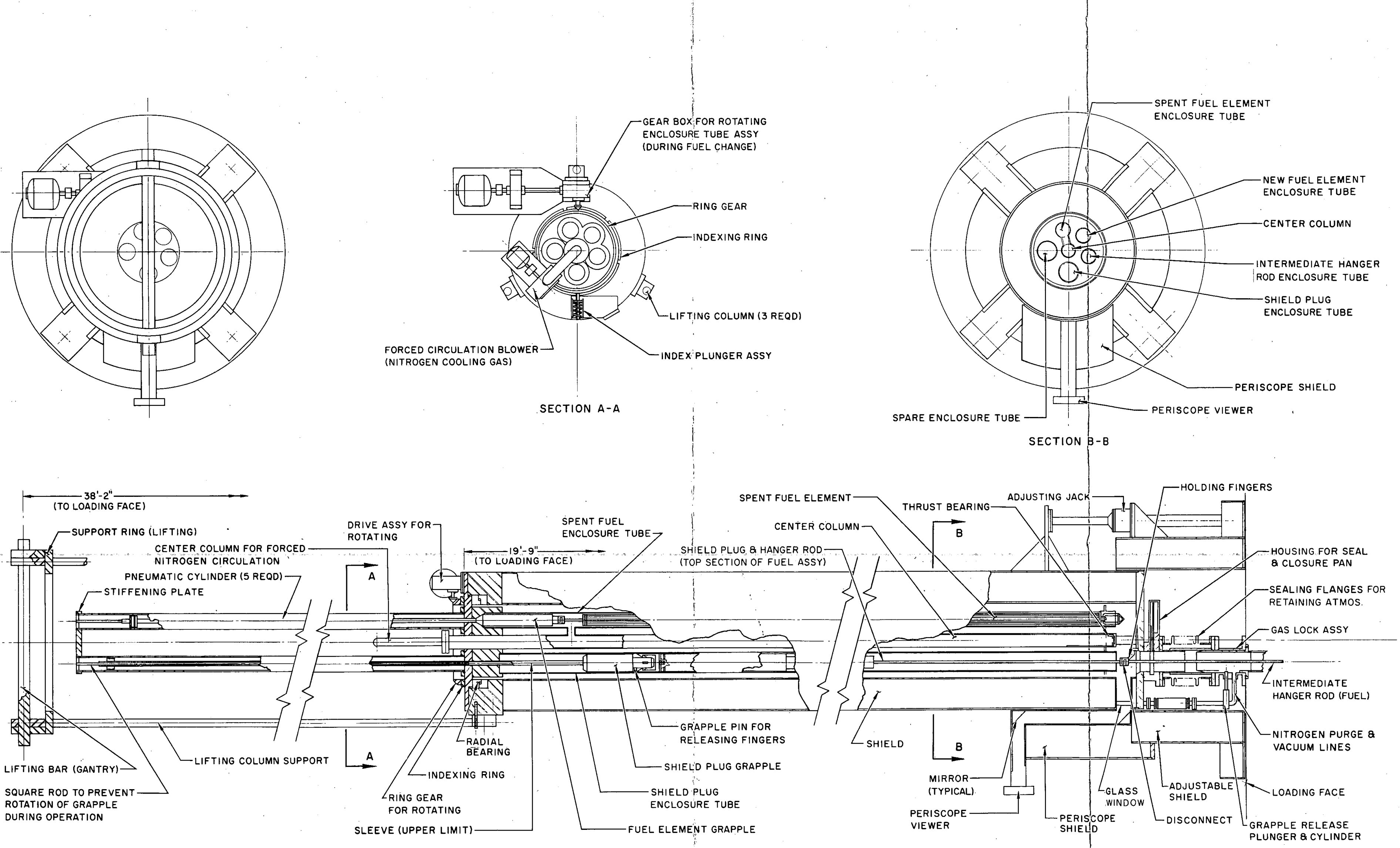

Figure 30. Fuel Handling Cask 
a

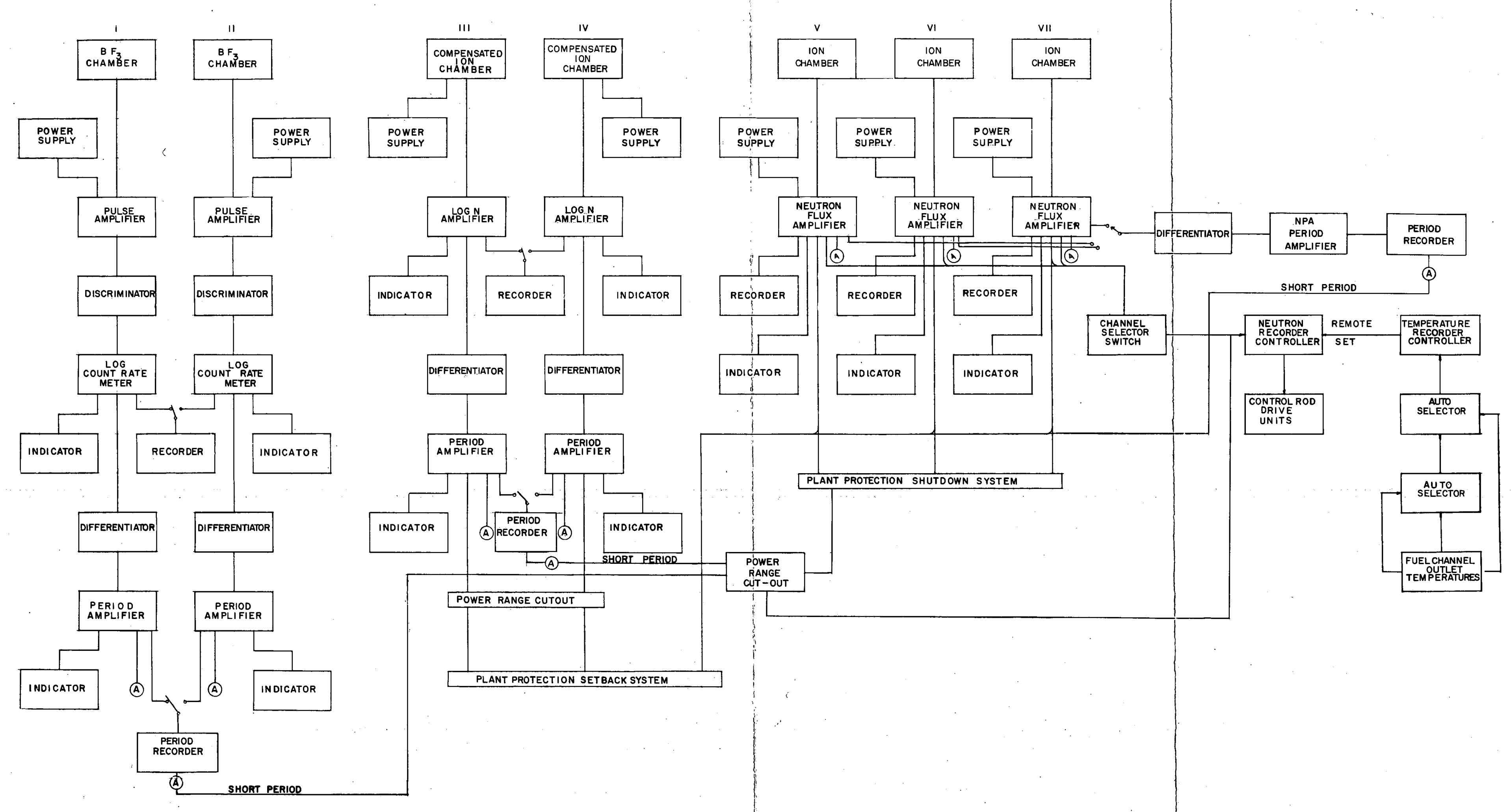




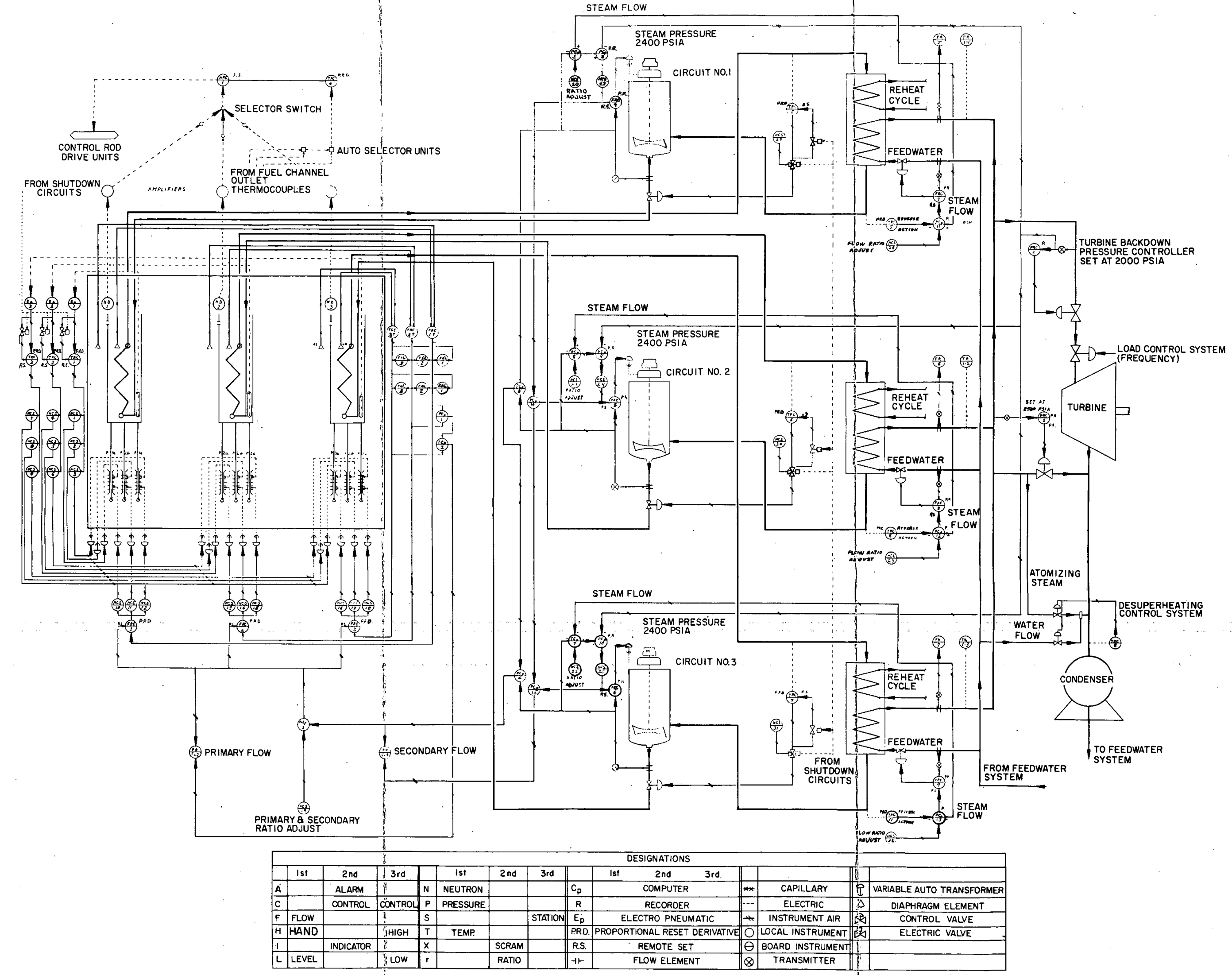

Figure 33. Primary Control Diagram 


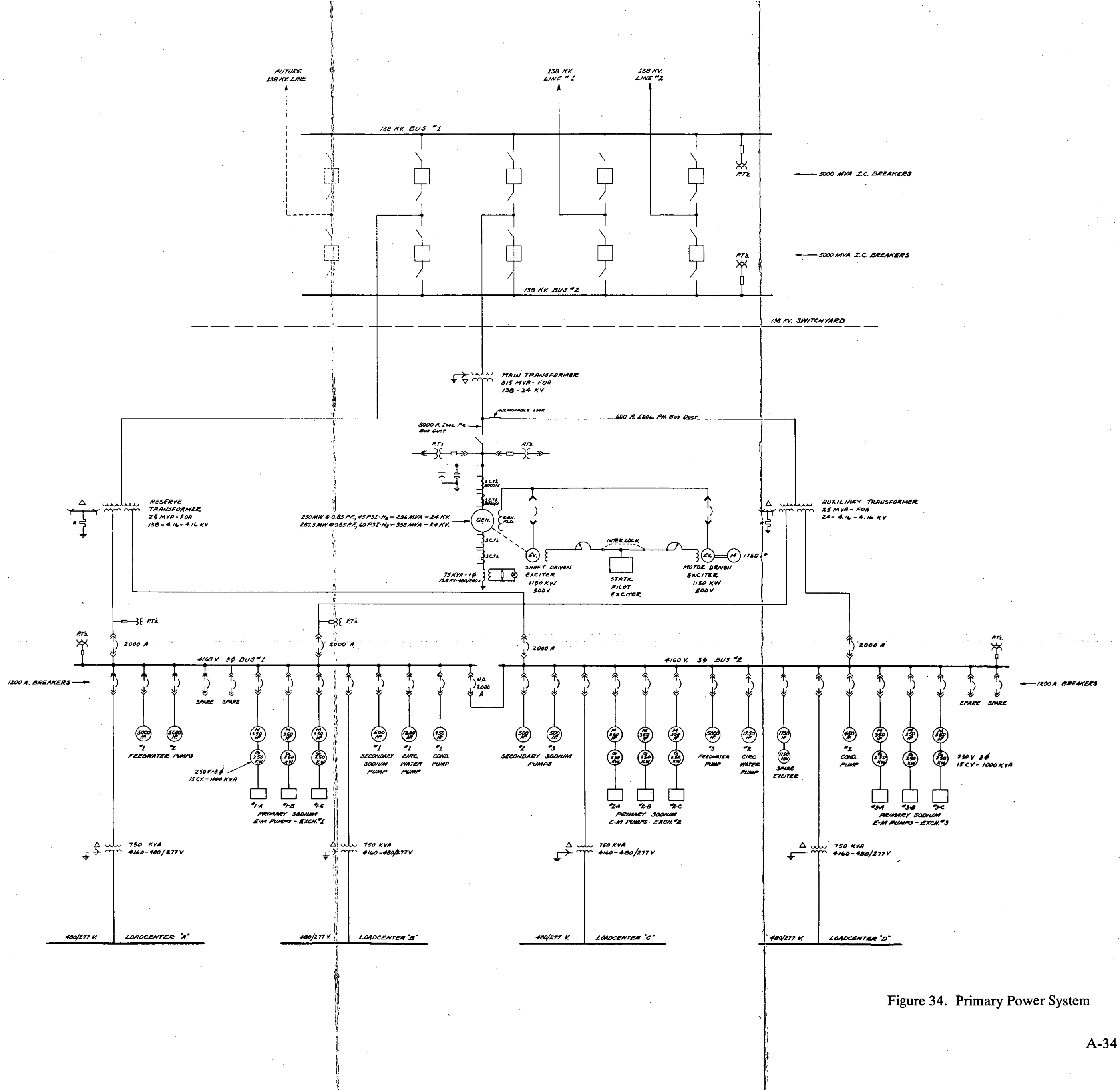




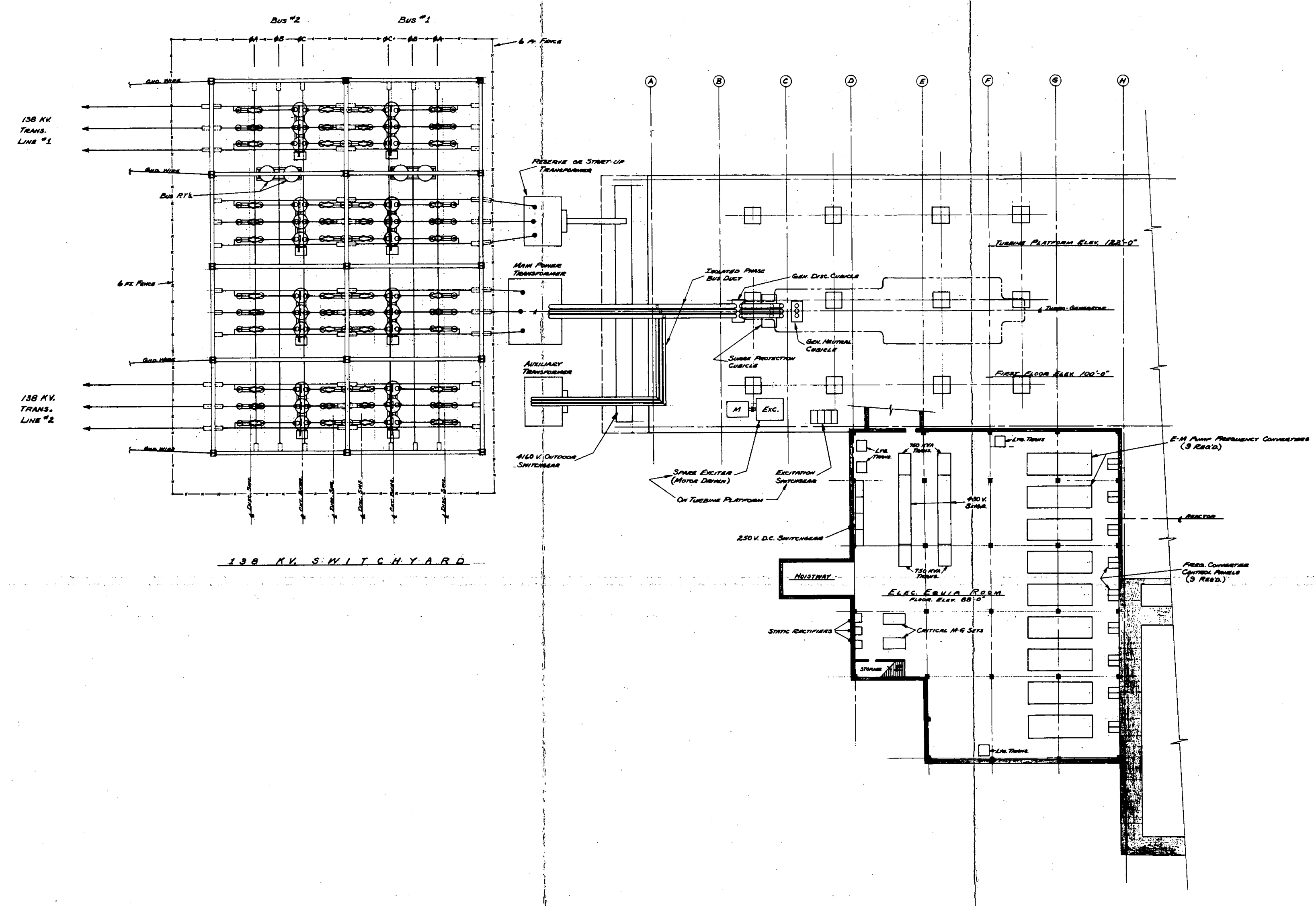

Figure 35. Electrical-Equipment Arrangement 


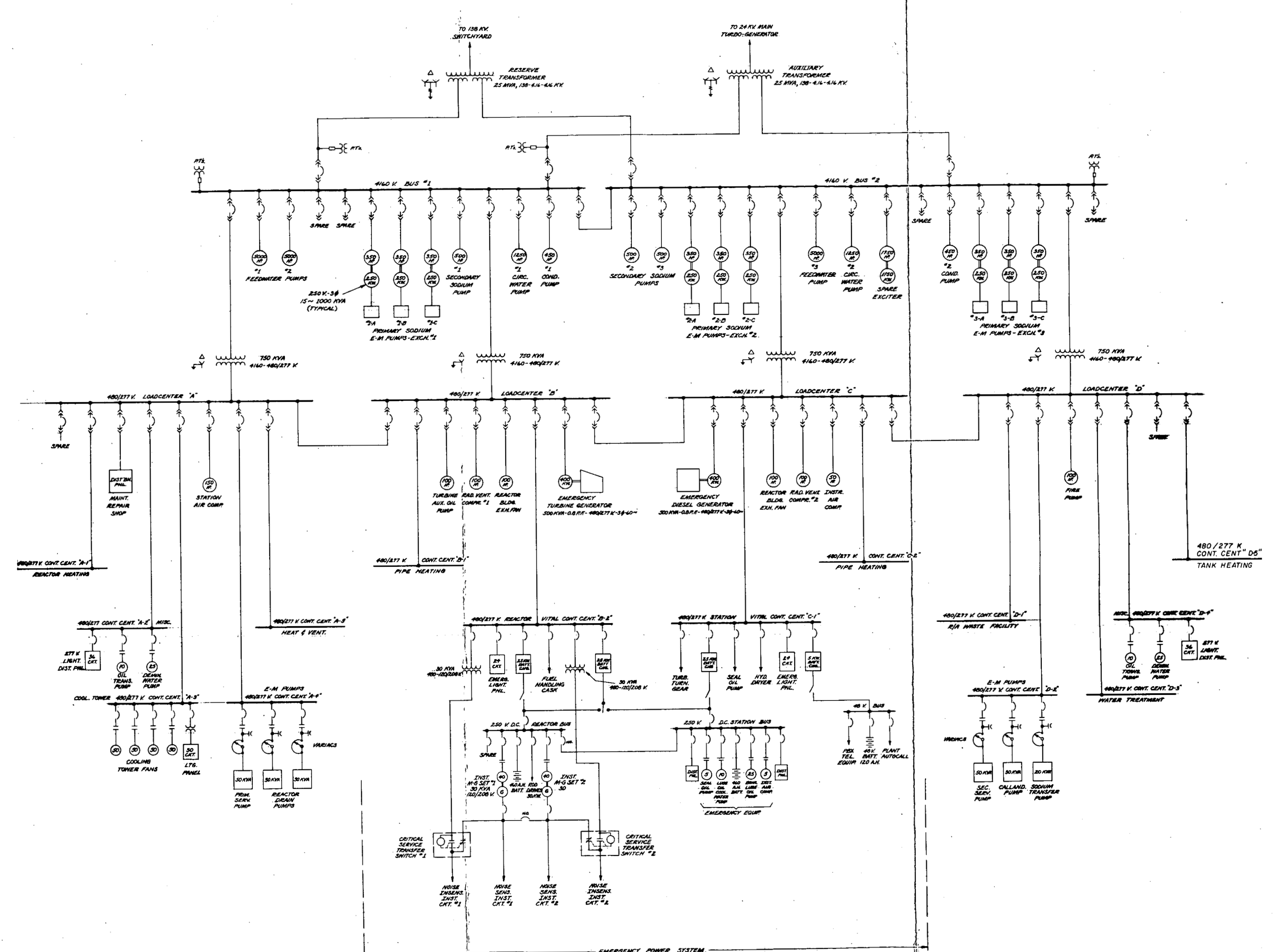

Figure 36. Auxiliary Power System 


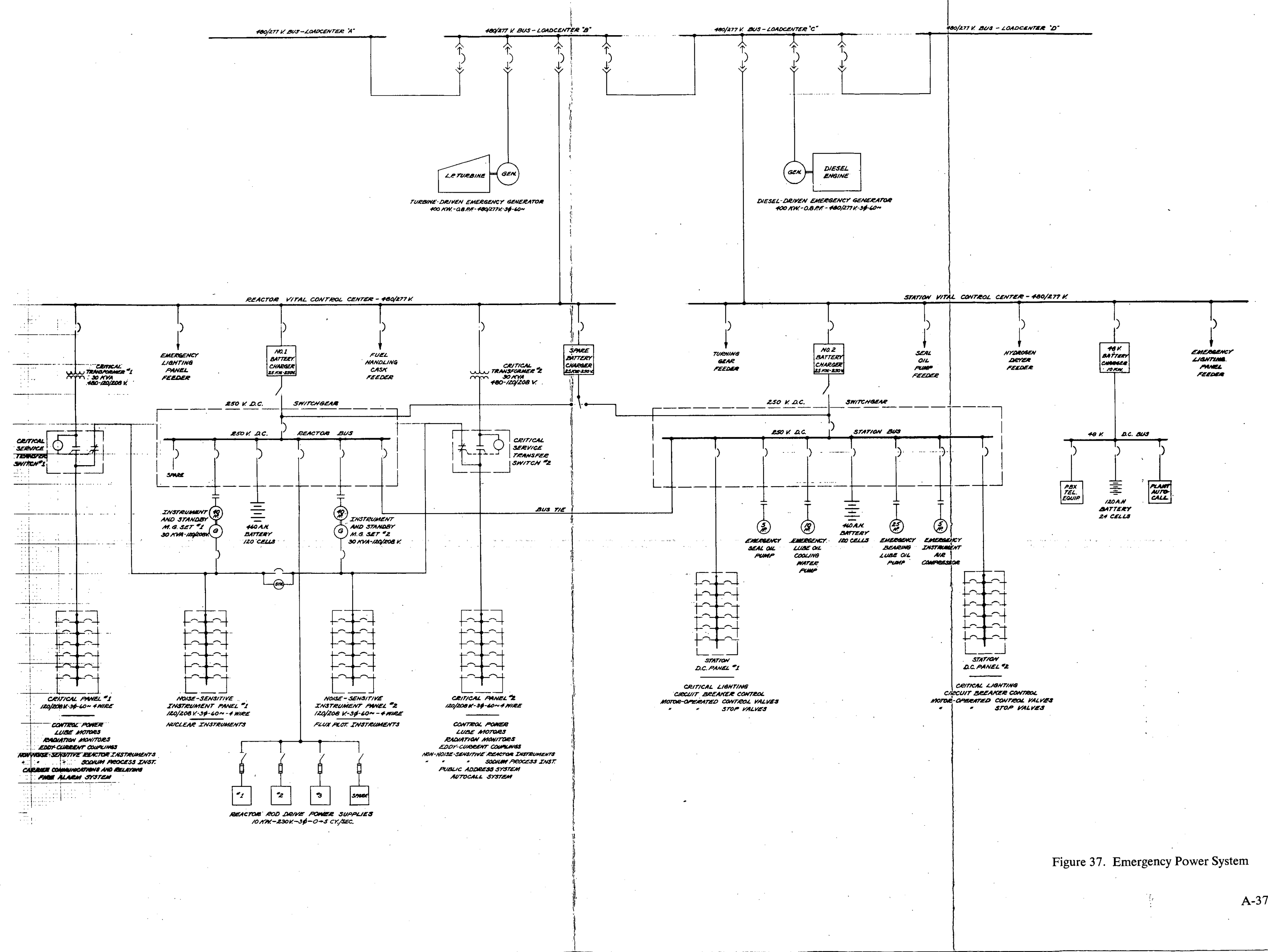




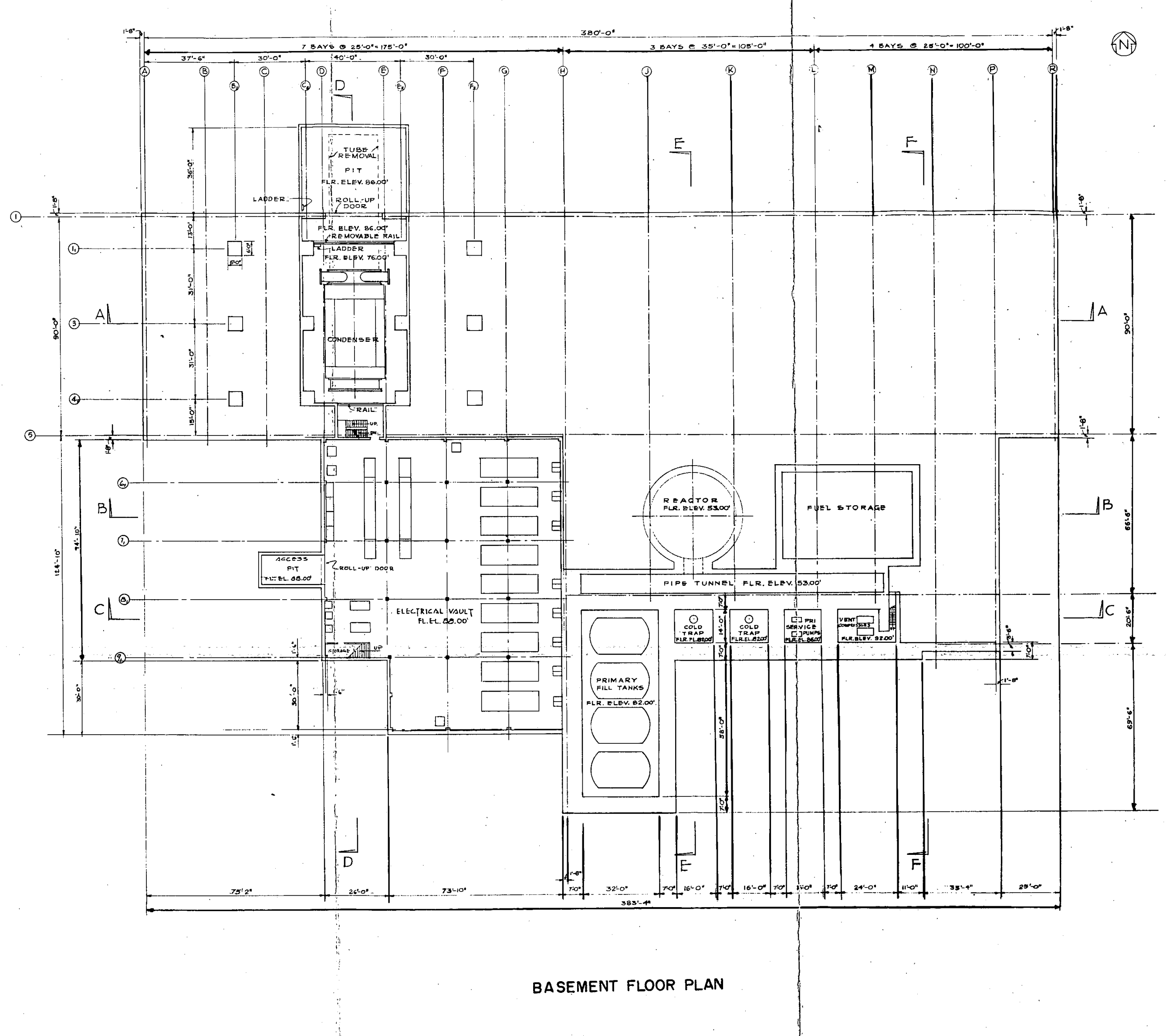

Figure 39. Basement Floor Plan 


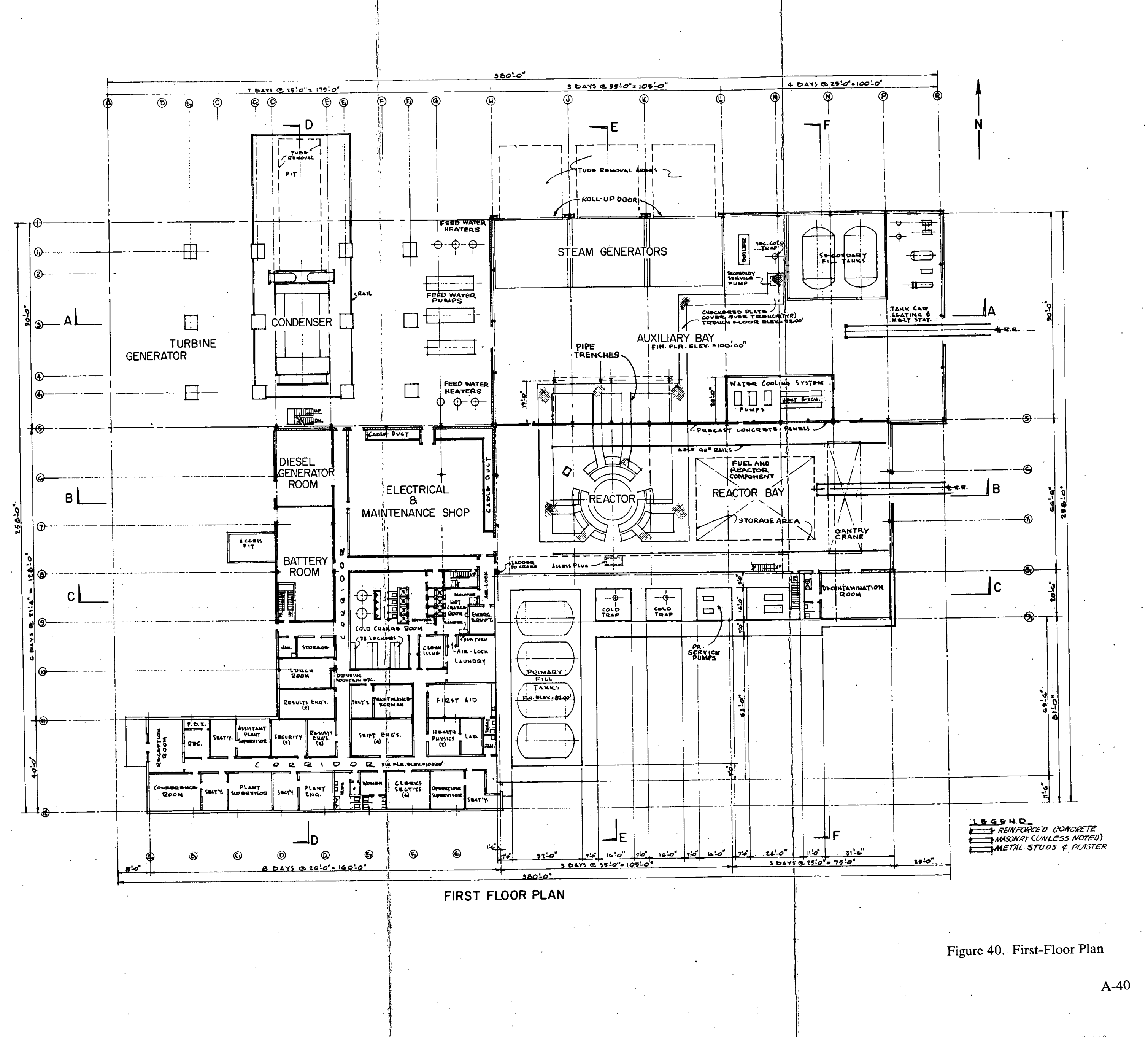



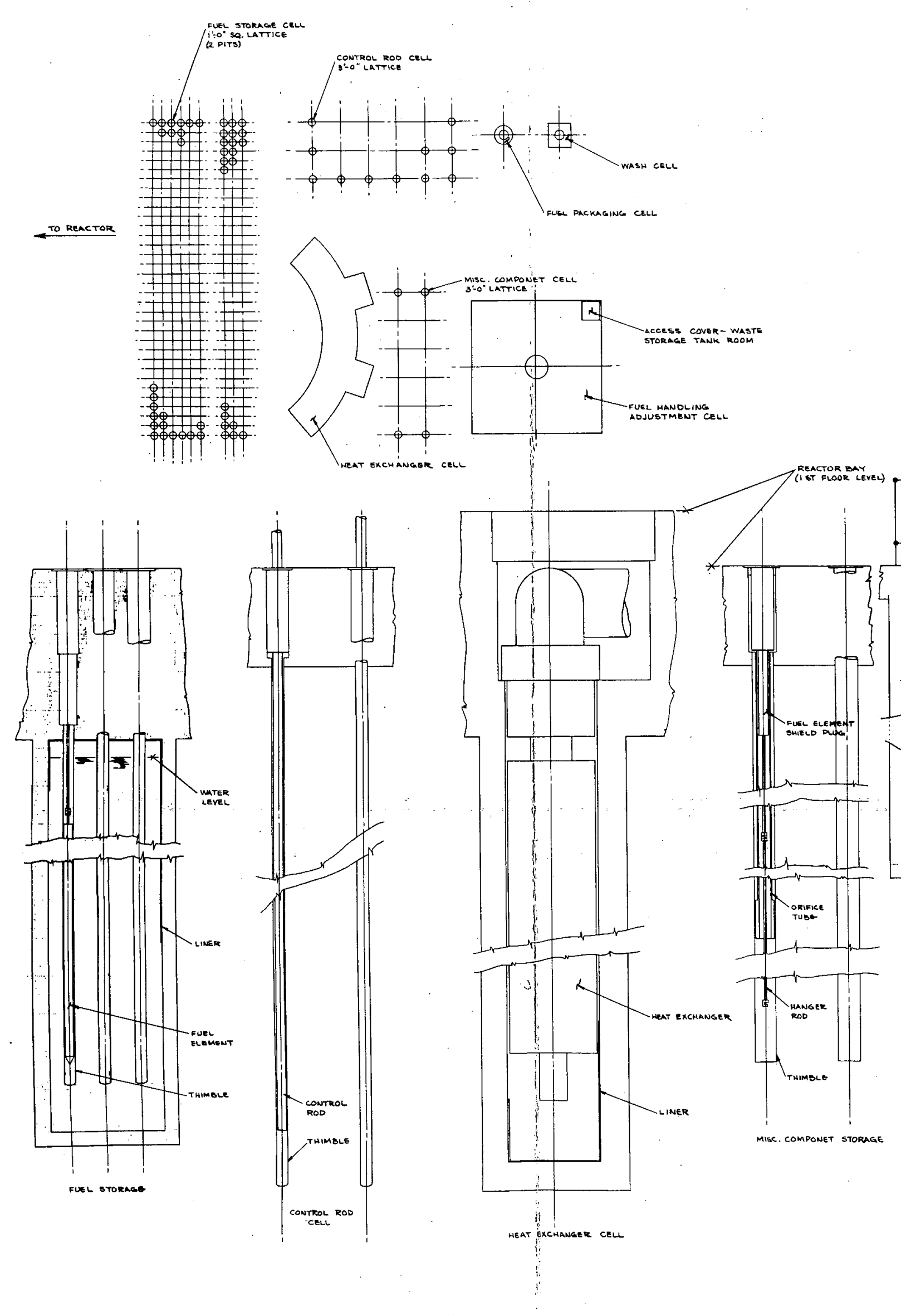

Figure 41. Reactor-Component Storage 


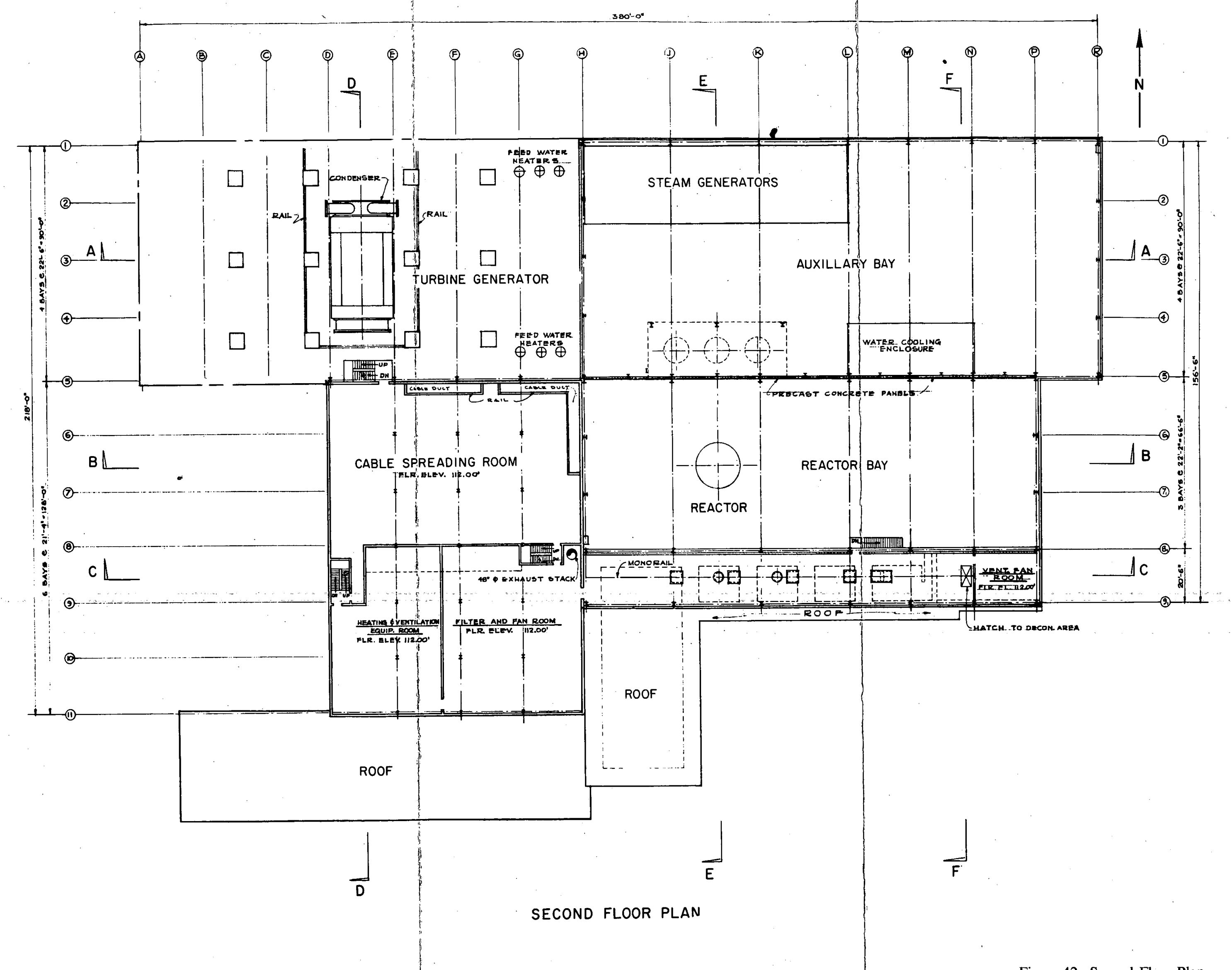

Figure 42. Second-Floor Plan 
$380^{\prime}-0^{\prime \prime}$

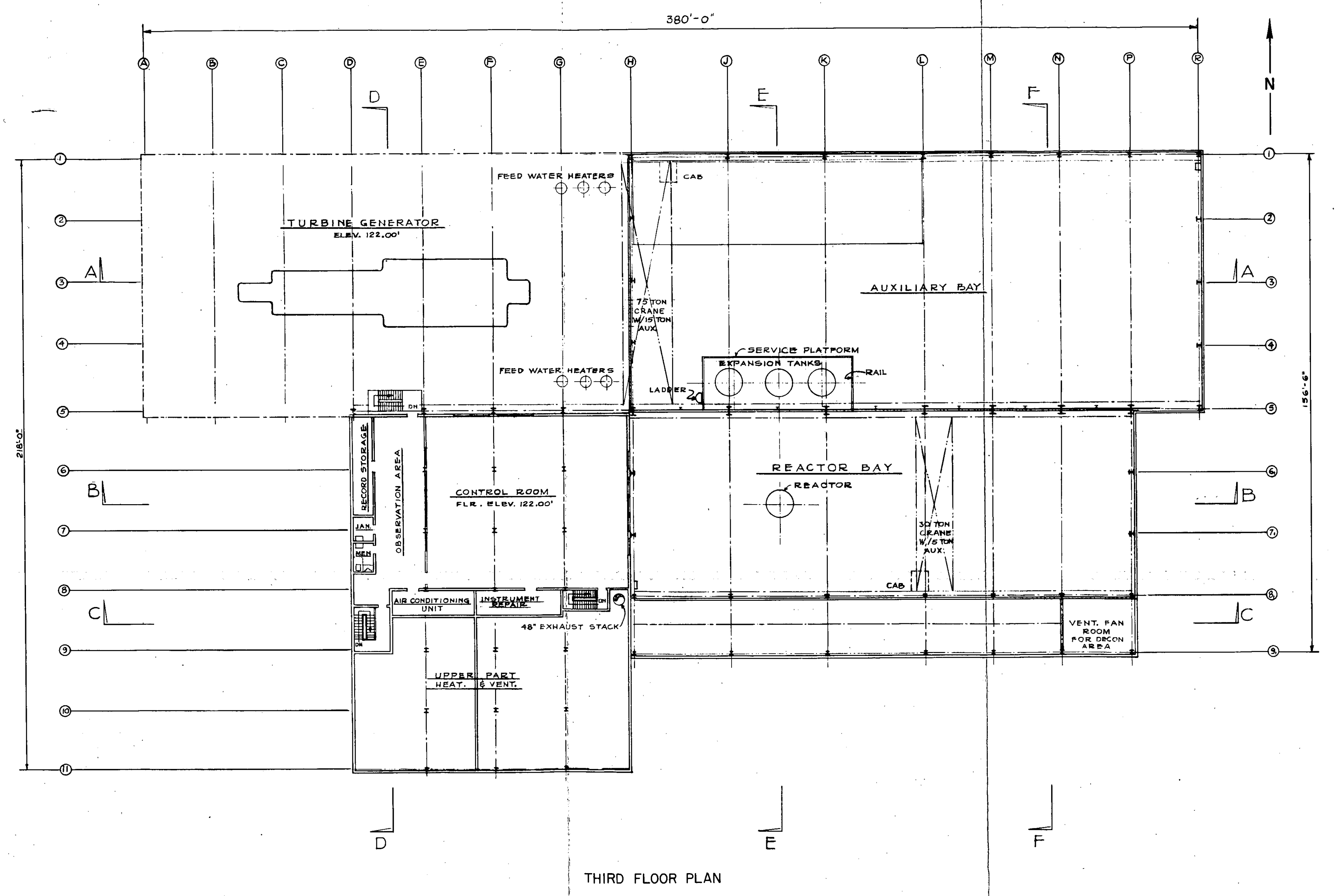




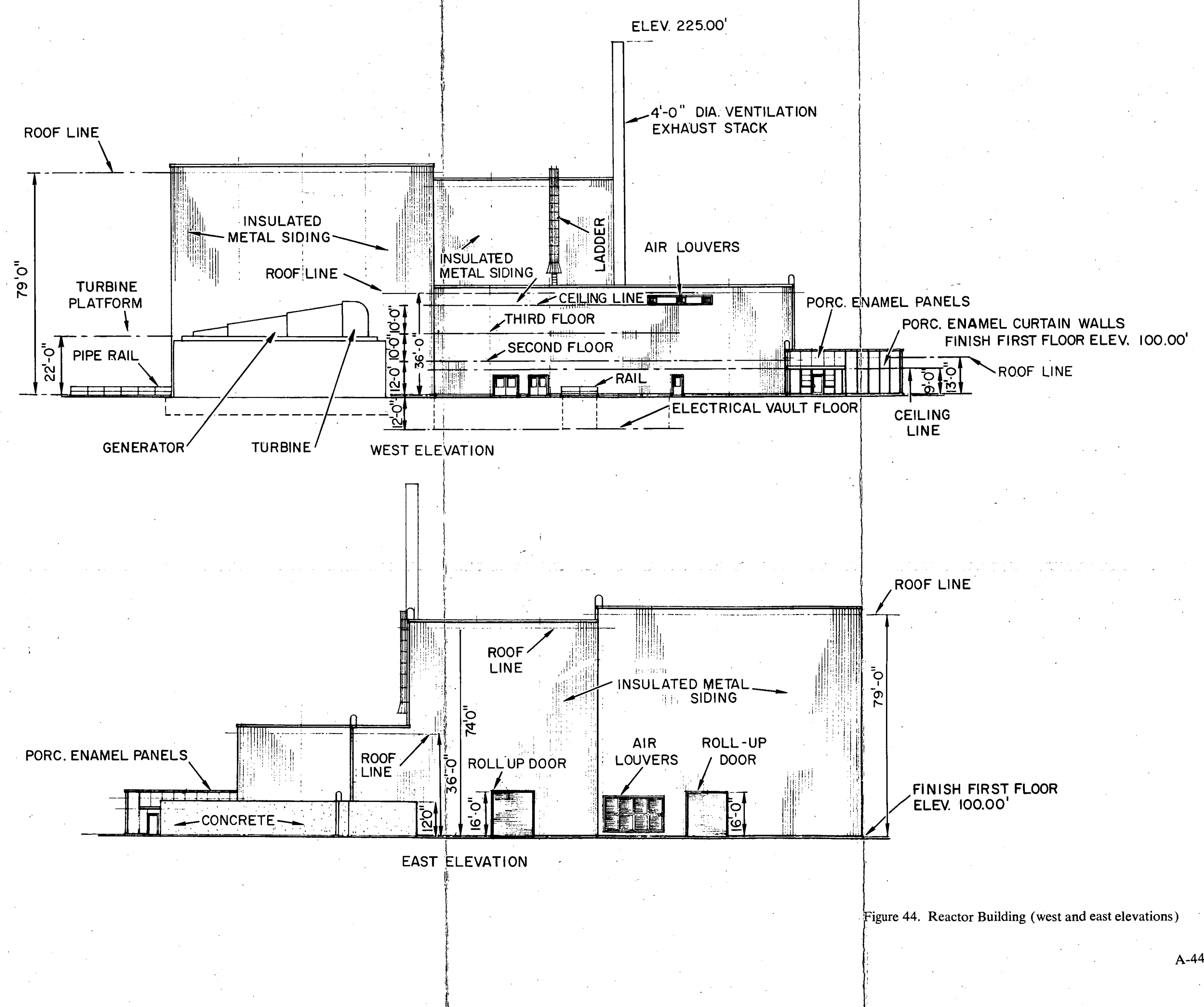


VENTILATION

EXHAUST STACK

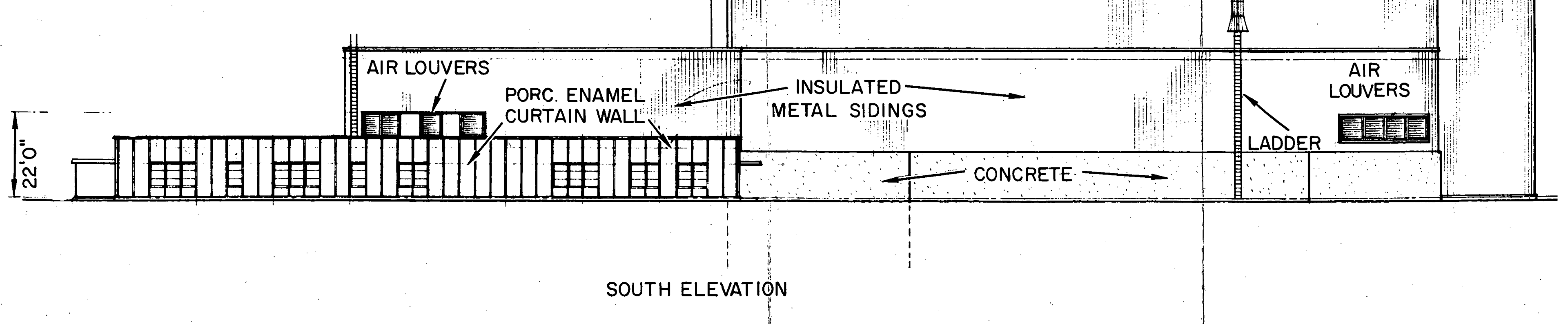

. Figure 45. Reactor Building (south elevation) 


\section{o}

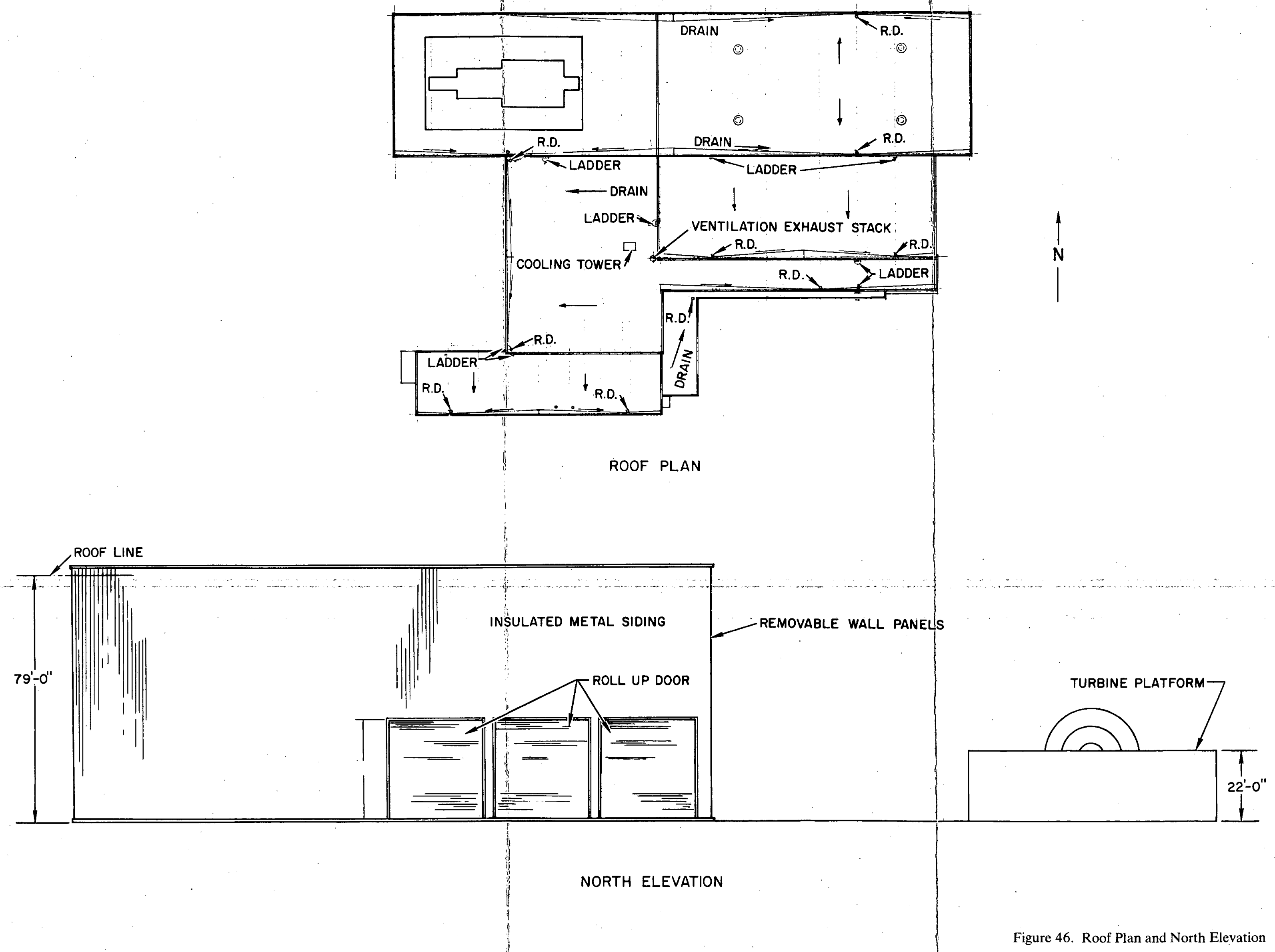



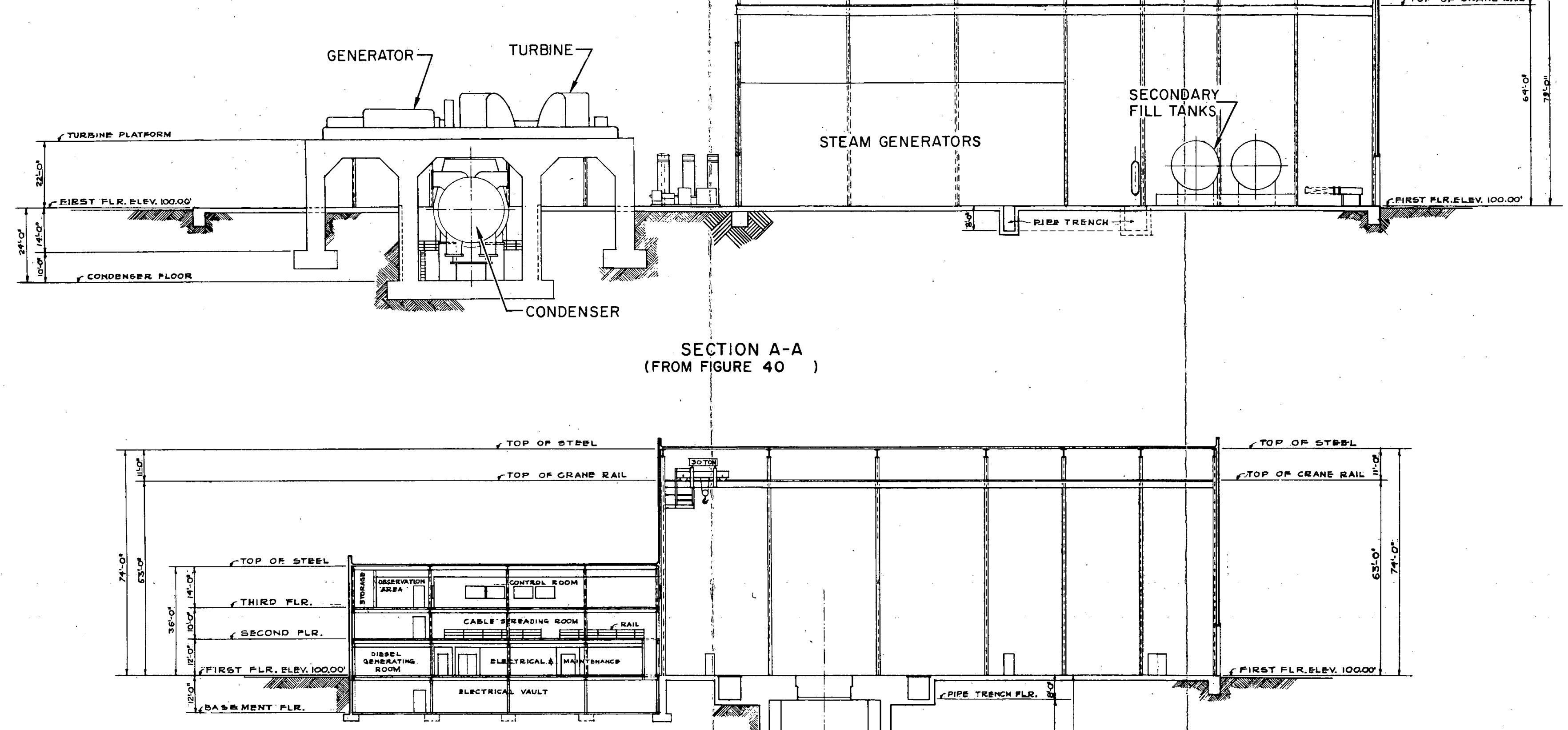

SECTION A-A,
(FROM FIGURE 40

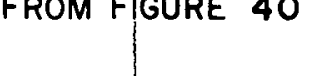




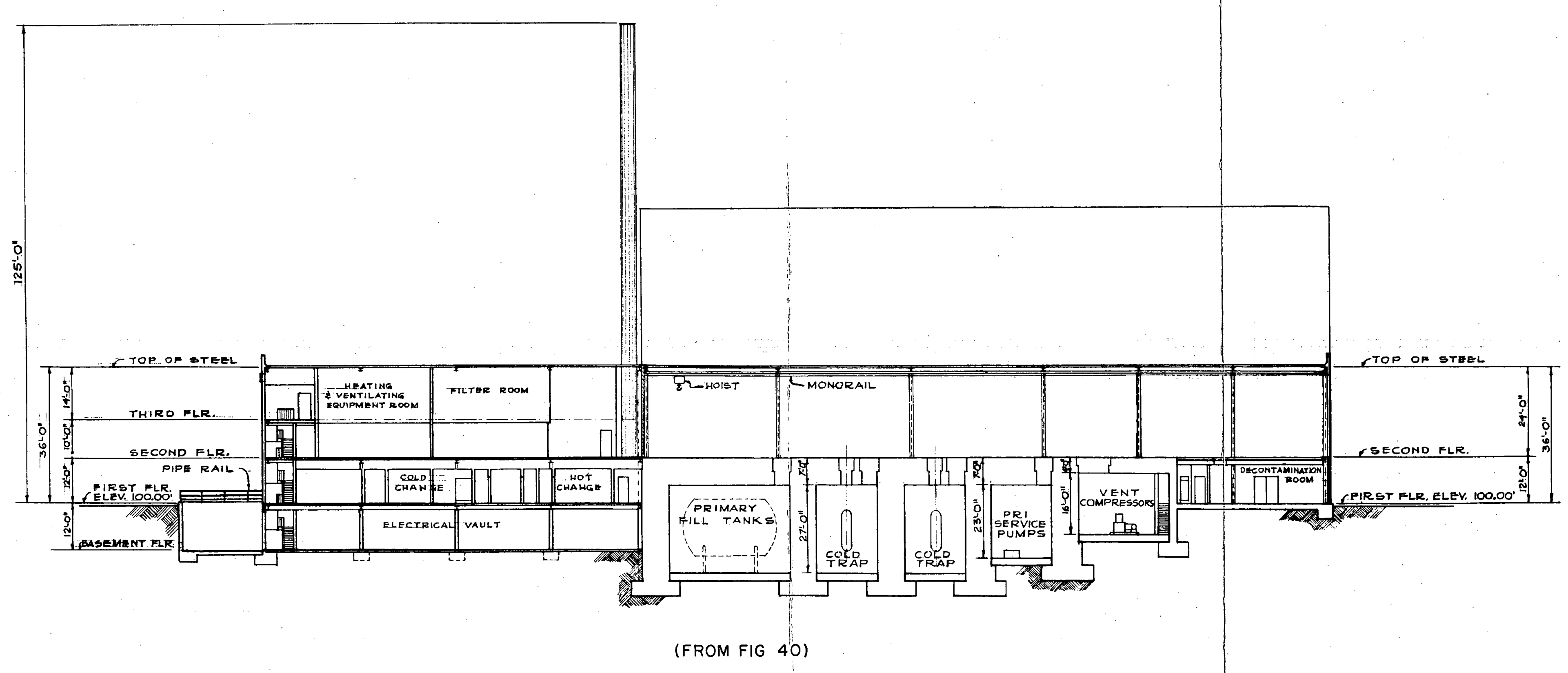



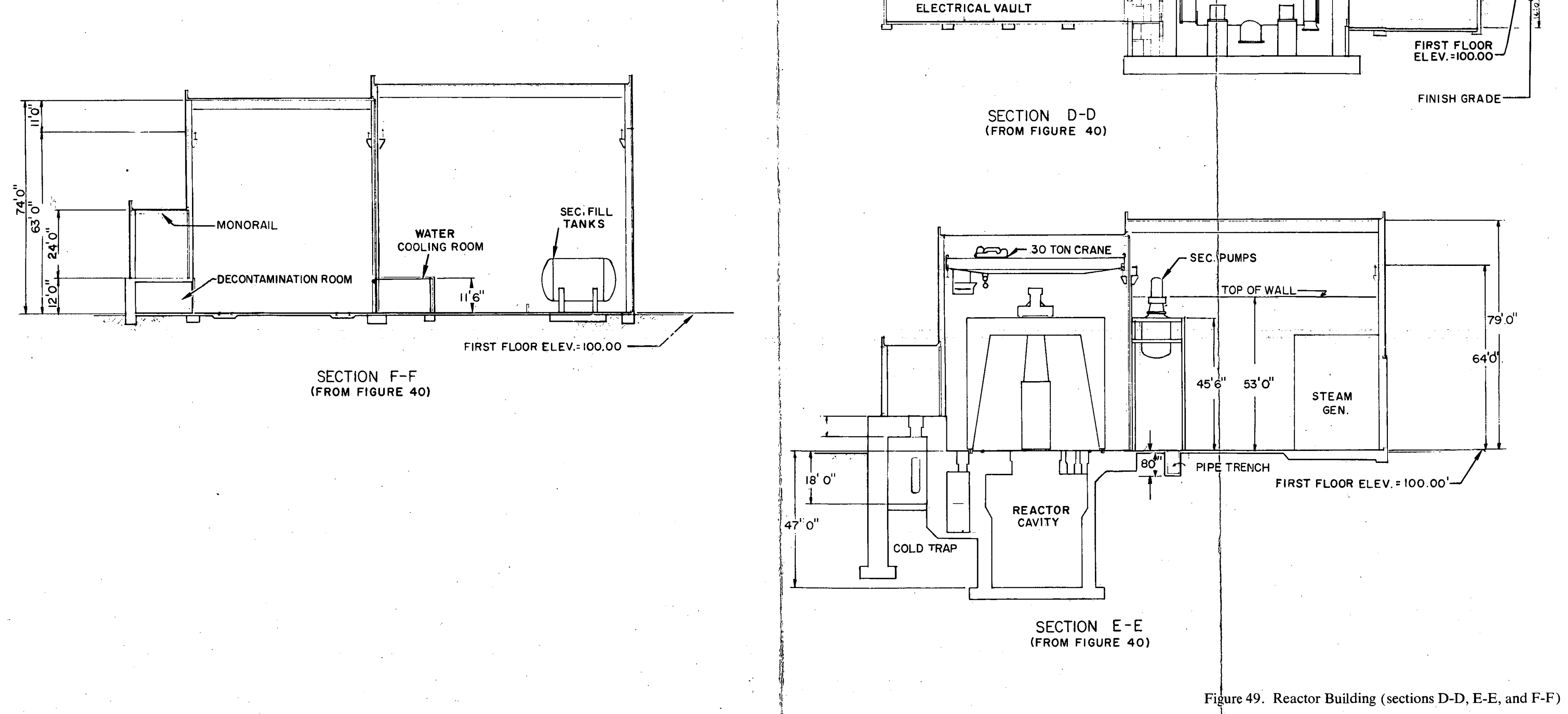


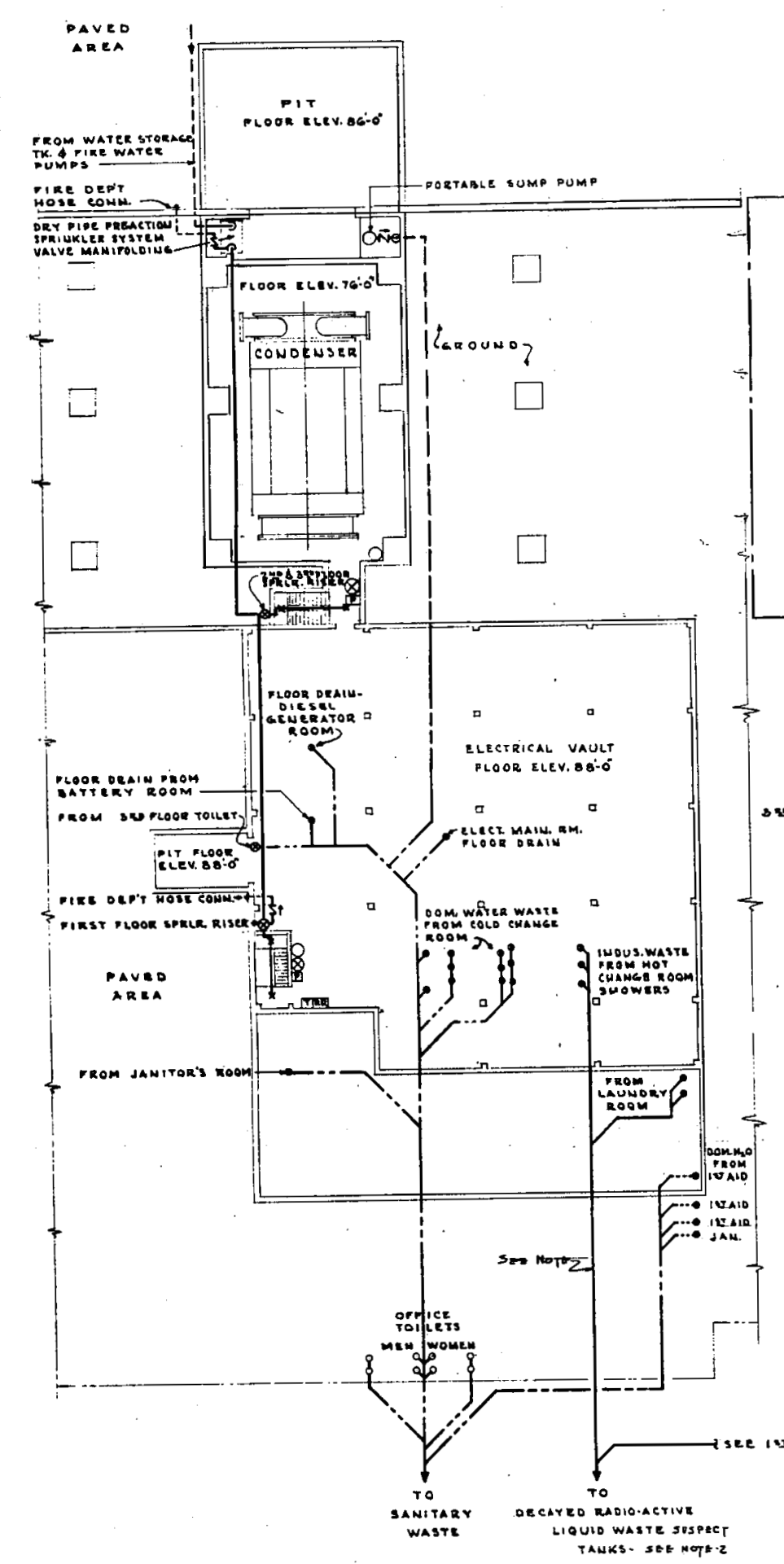

BASEMENT PLAN

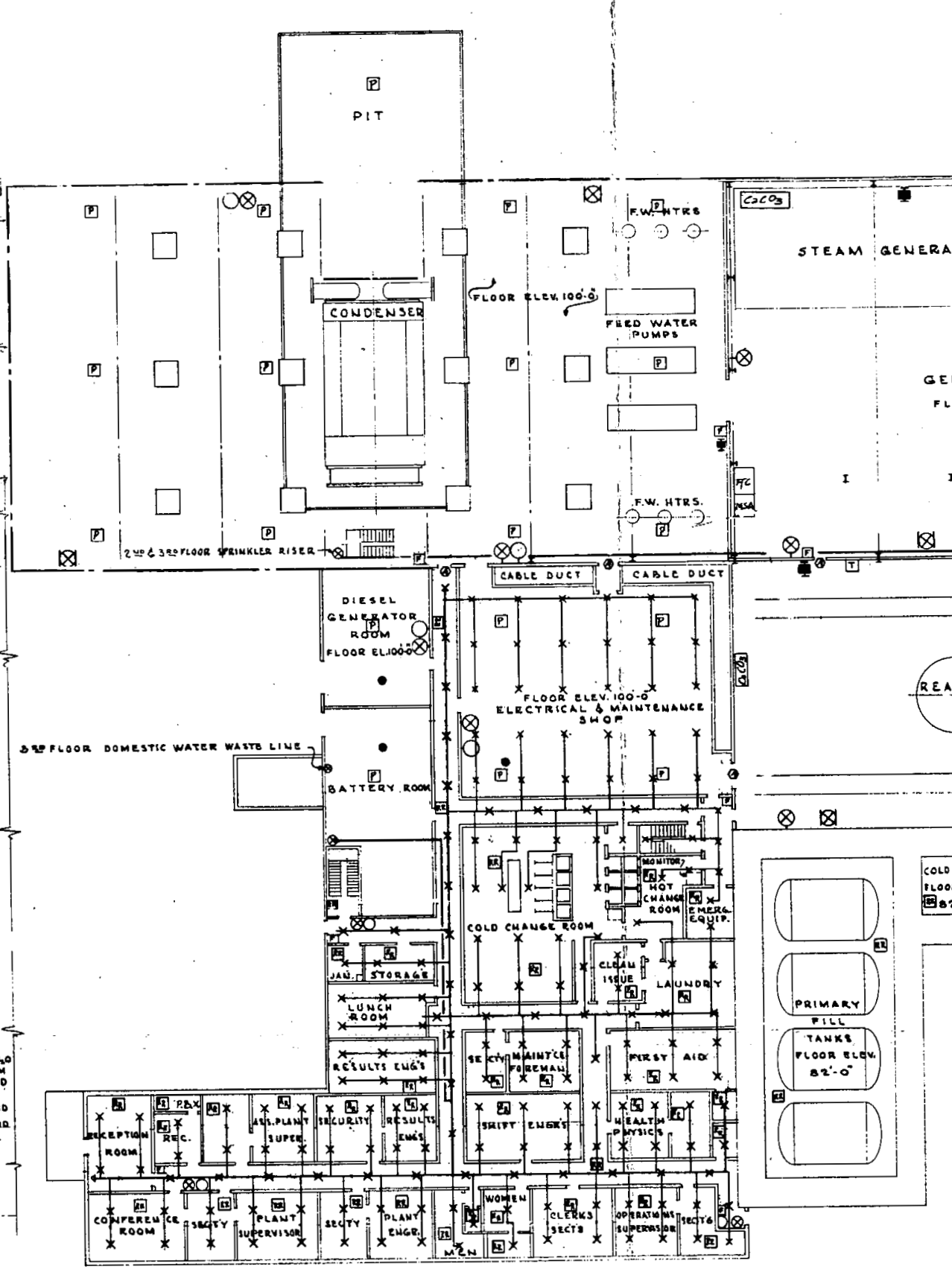

see snivem 


\section{o}

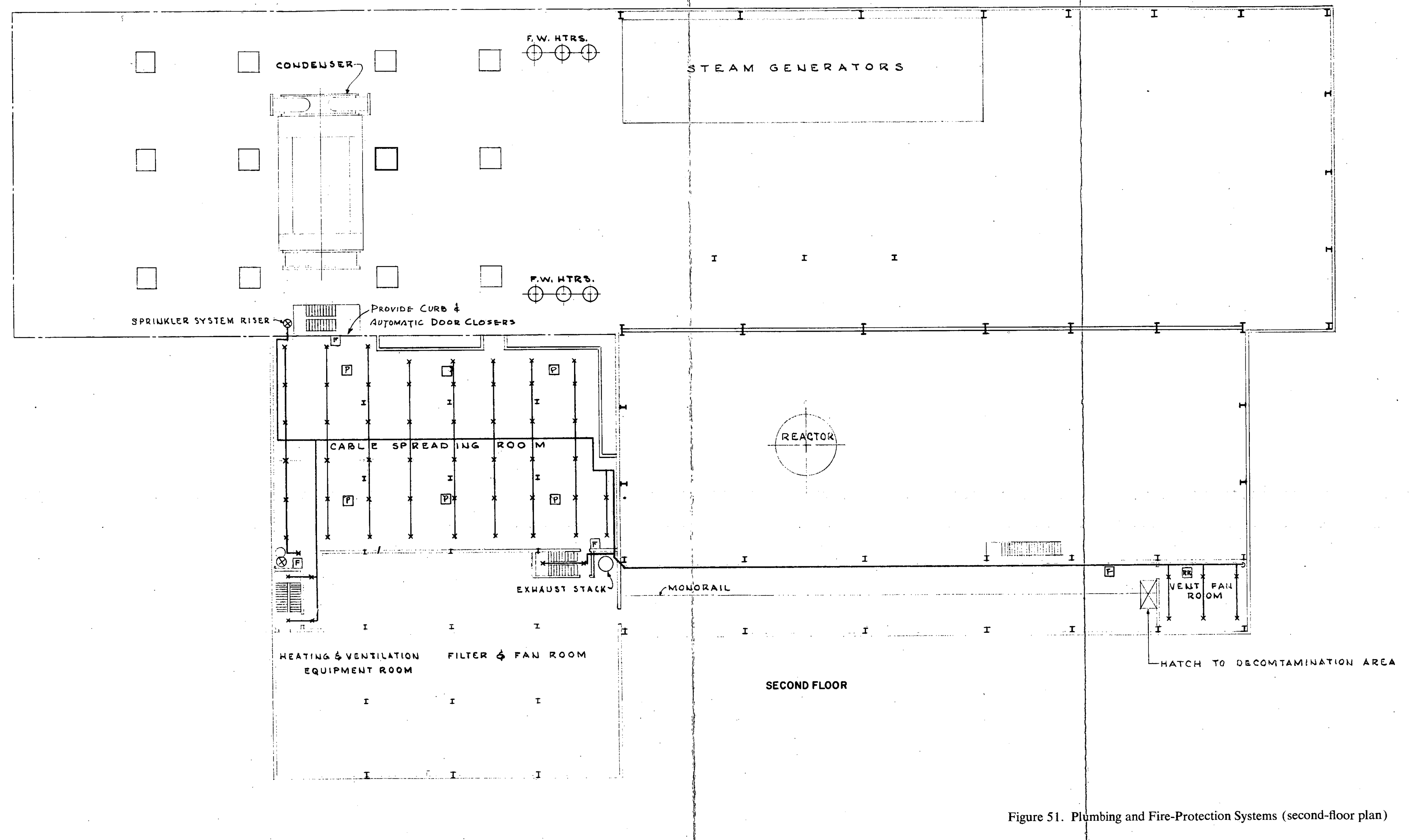




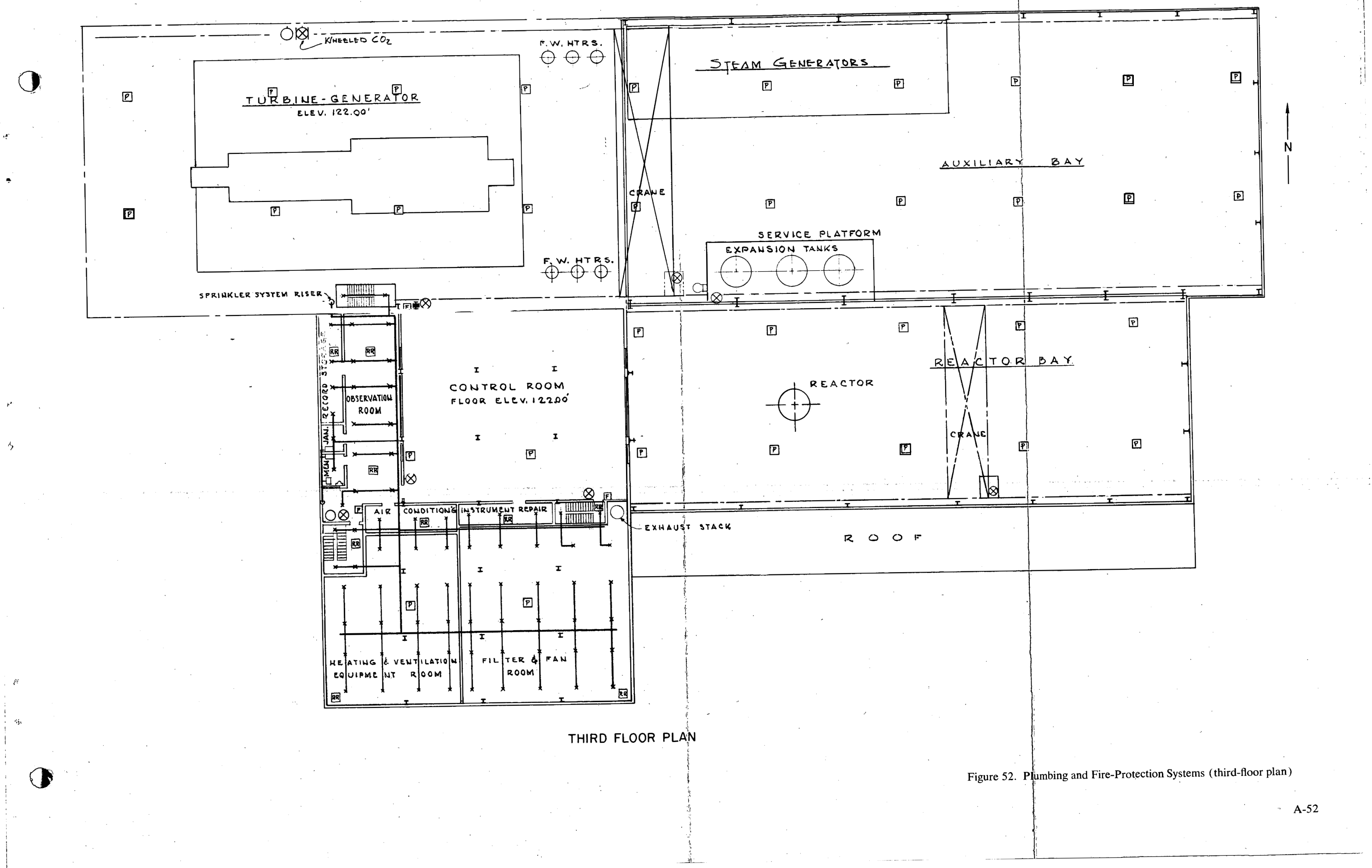



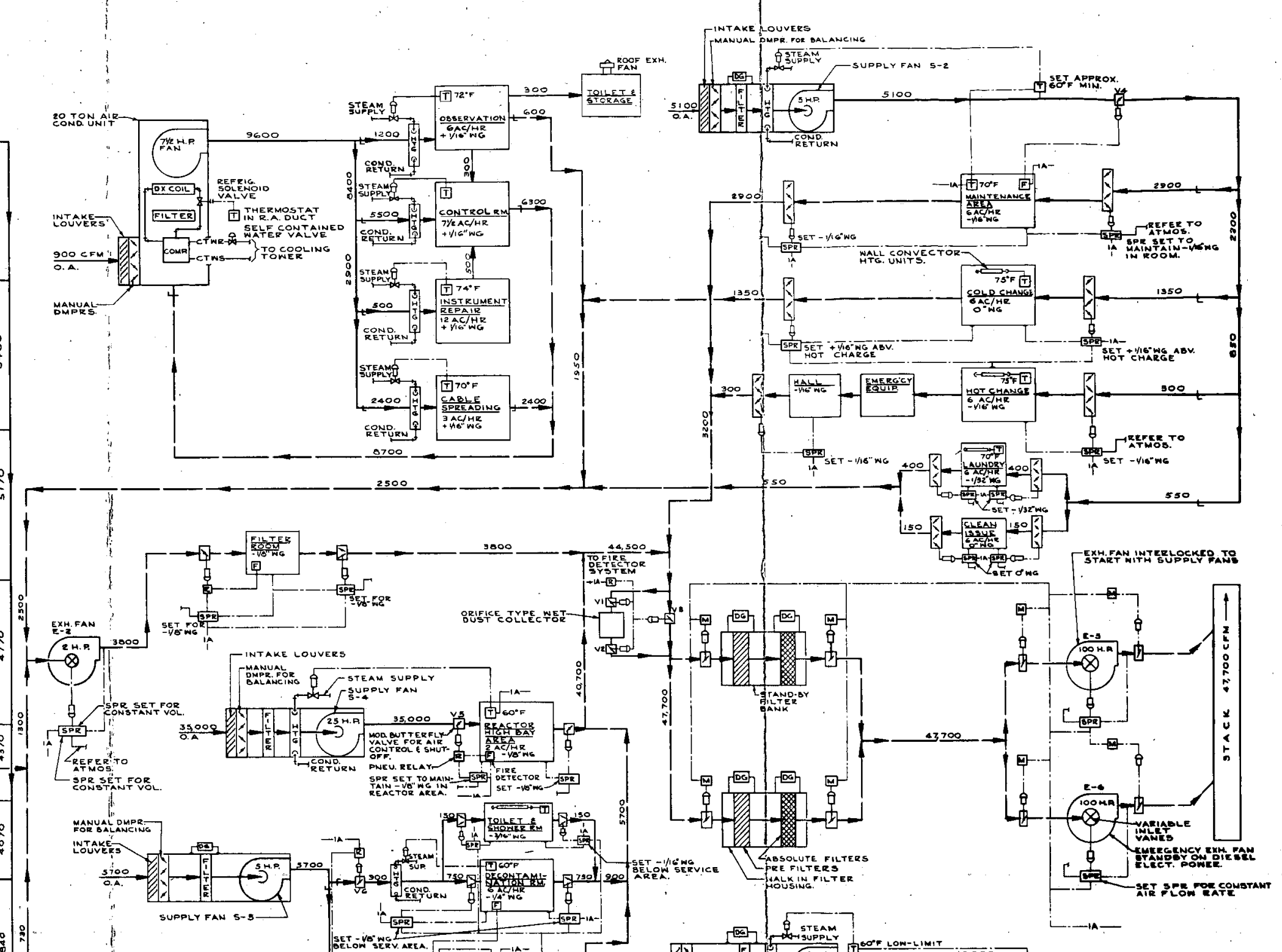

12

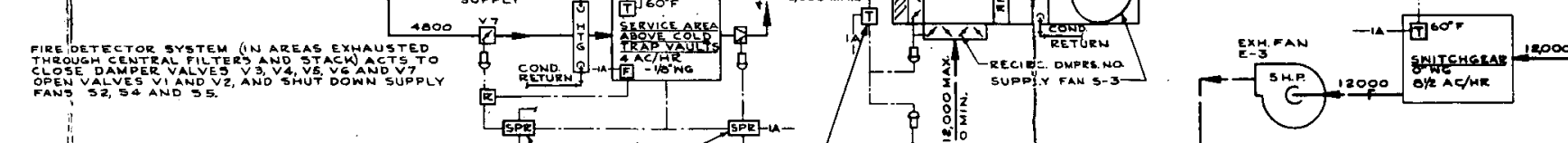

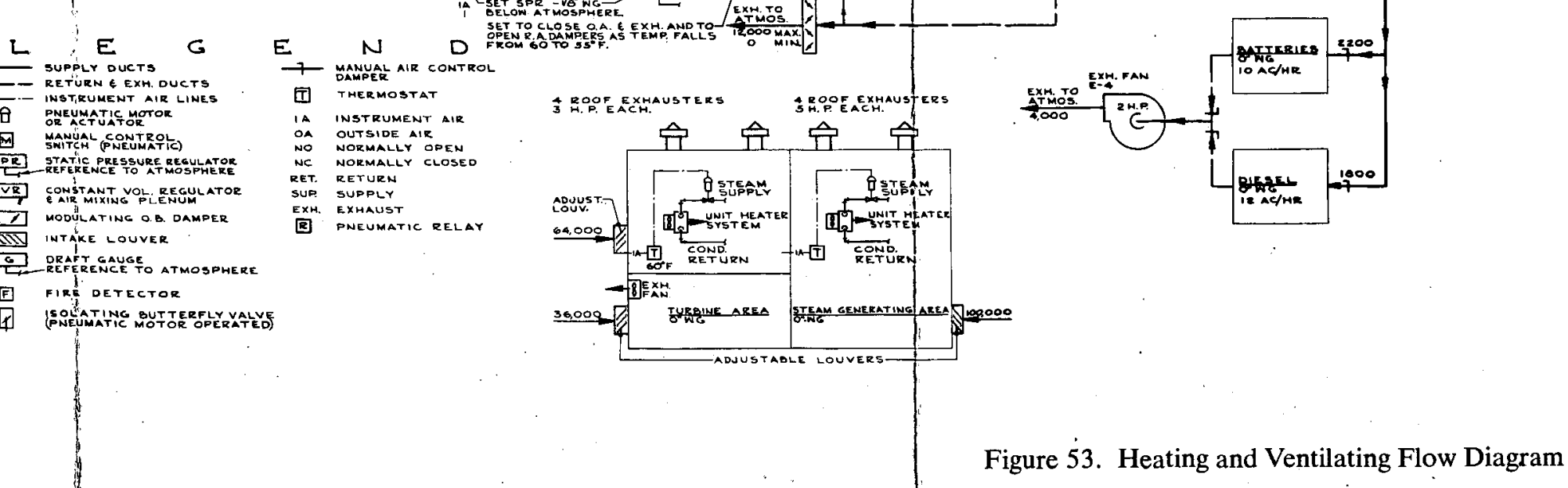




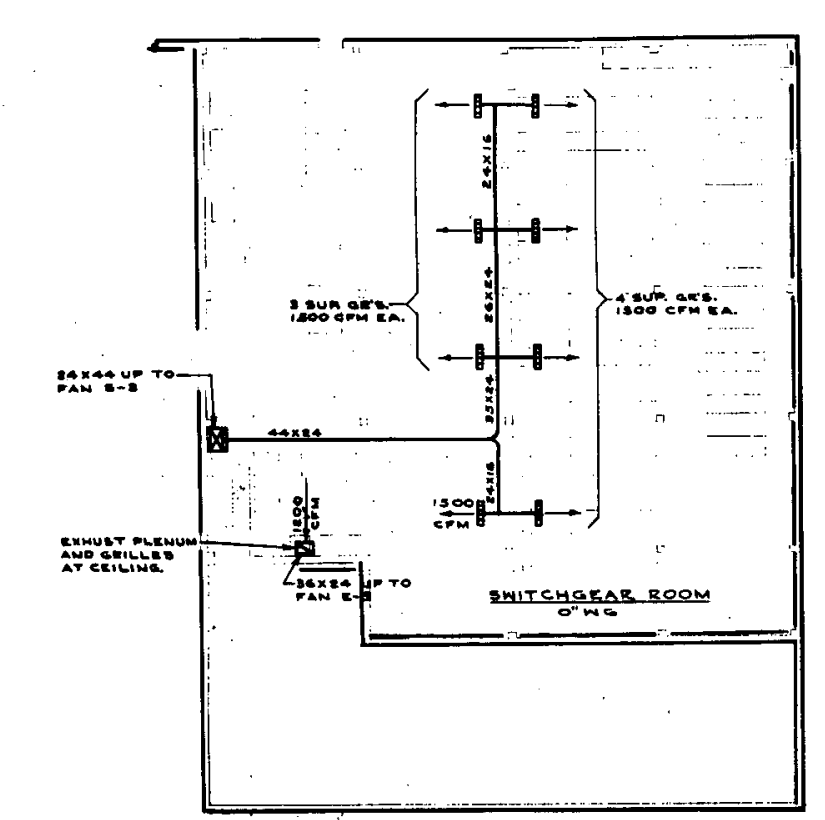

BASEMENT PLAN-ELEV OB-O"

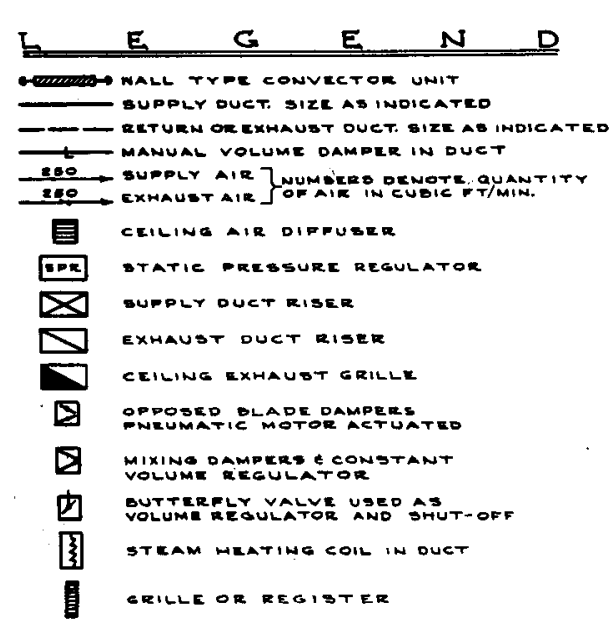

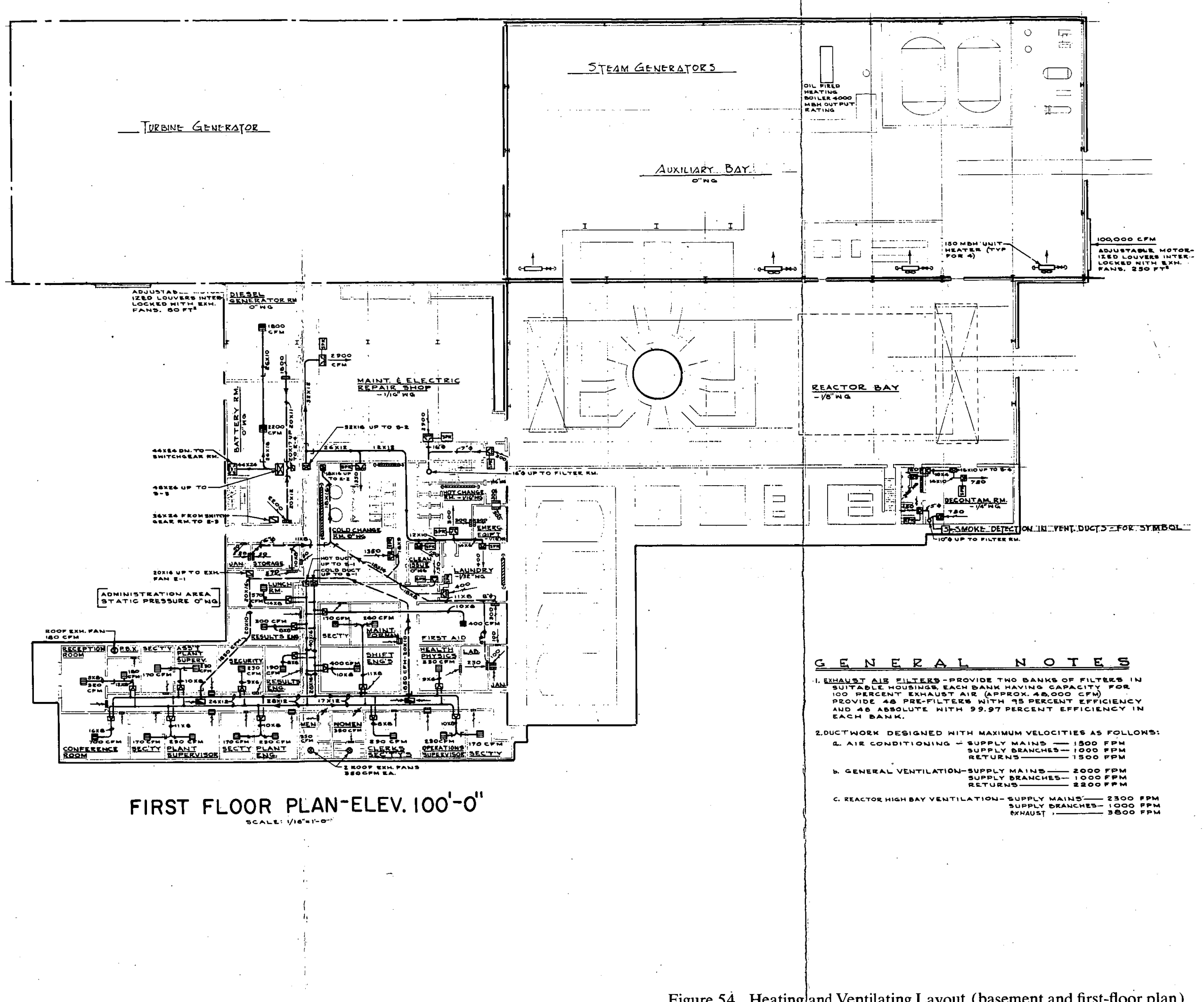

Figure 54. Heating and Ventilating Layout (basement and first-floor plan) 


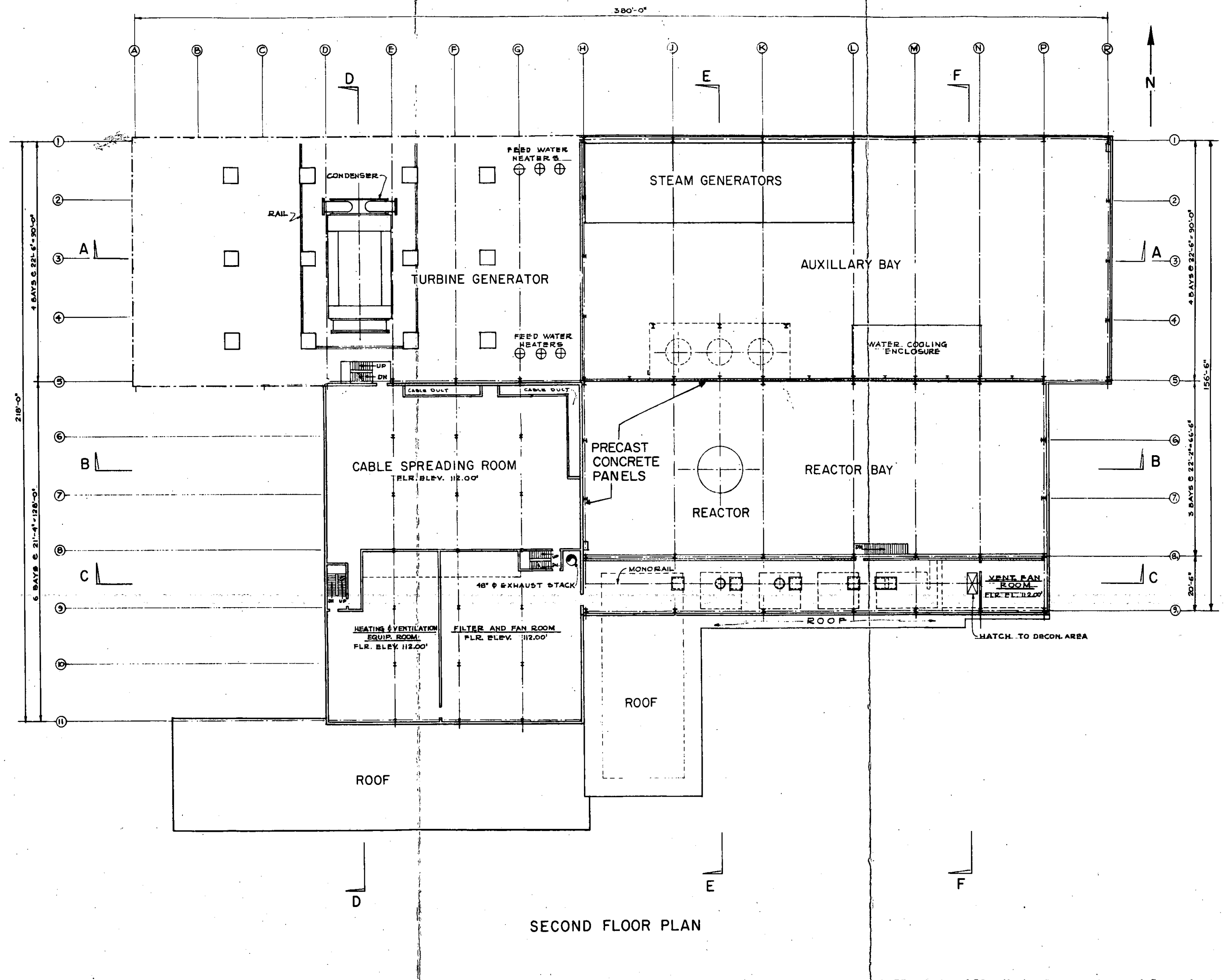

Figure 55. Heating and Ventilating Layout (second-floor plan) 
(8)

UPPER PART TURBINE AREA

(8)

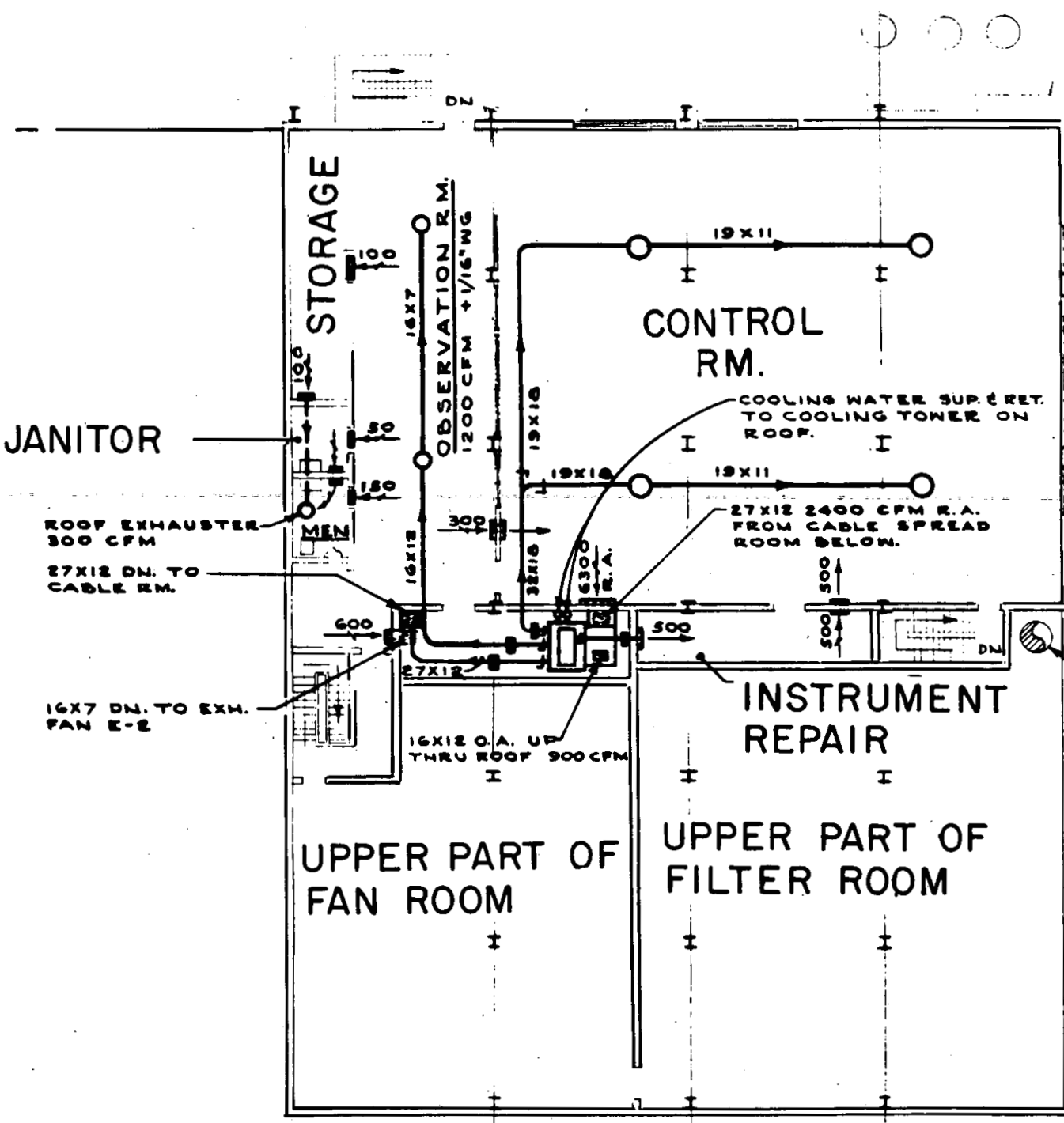

(8)

(8)

UPPER PART STEAM GENERATING AREA

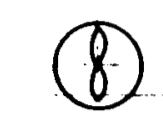

(8)

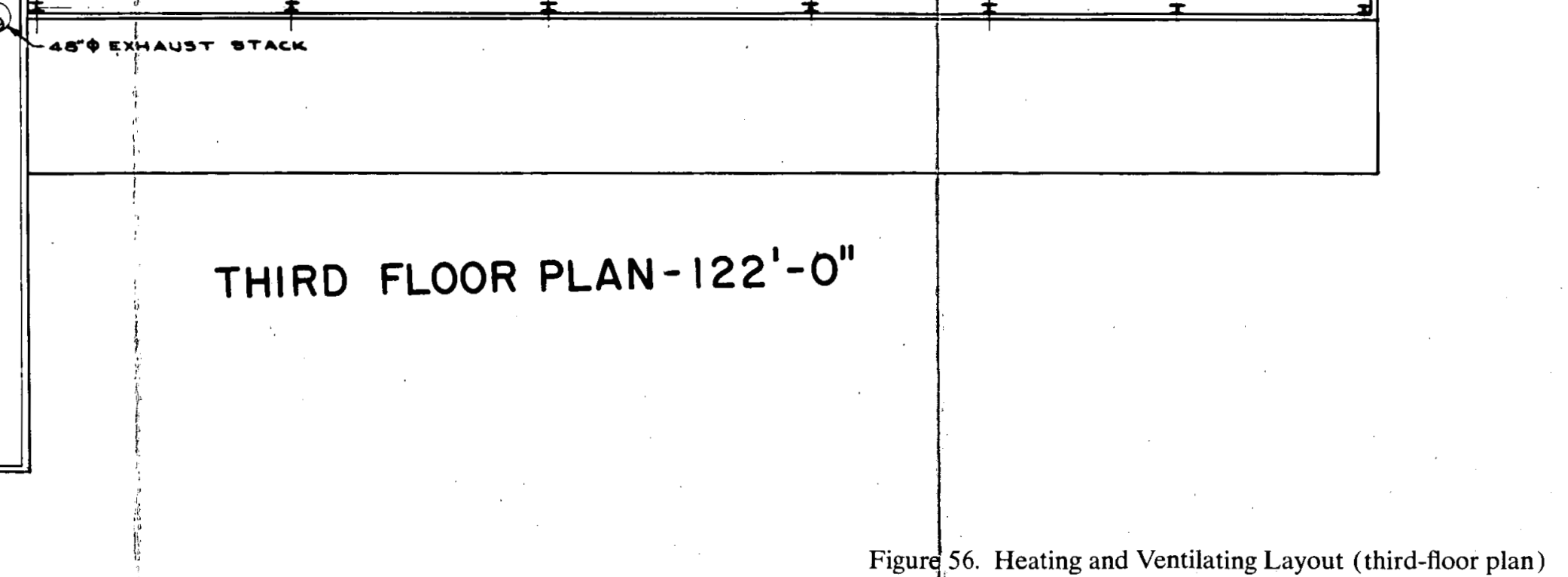

